\title{
Martina Lindseth
}

\section{Null-Subject Properties of Slavic Languages}

\section{With Special Reference to Russian, Czech and Sorbian}

Verlag Otto Sagner München · Berlin · Washington D.C.

Digitalisiert im Rahmen der Kooperation mit dem DFG-Projekt „Digi20“

der Bayerischen Staatsbibliothek, München. OCR-Bearbeitung und Erstellung des eBooks durch den Verlag Otto Sagner:

http://verlag.kubon-sagner.de

( bei Verlag Otto Sagner. Eine Verwertung oder Weitergabe der Texte und Abbildungen, insbesondere durch Vervielfältigung, ist ohne vorherige schriftliche Genehmigung des Verlages unzulässig. 


\title{
SLAVISTISCHE BEITRÄGE
}

\author{
Begründet von
}

Alois Schmaus

\author{
Herausgegeben von \\ Peter Rehder
}

\author{
Beirat: \\ Tilman Berger - Walter Breu - Johanna Renate Döring-Smimov \\ Wilfried Fiedler - Walter Koschmal · Ulrich Schweier - Miloß Sedmidubský · Klaus Steinke
}

BAND 361 


\section{Martina Lindseth}

\section{Null-Subject Properties \\ of Slavic Languages With Special Reference to Russian, Czech and Sorbian}

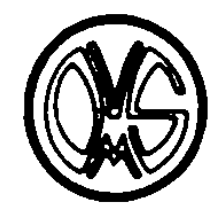

VERLAG OTTO SAGNER MÜNCHEN 1998 
PVA

98.

2677

Bayerische Staatsbibliothek Münctien

\section{ISBN 3-87690-699-7}

(c) Verlag Otto Sagner, München 1998 Abteilung der Firma Kubon \& Sagner D-80328 München 


\section{ACKNOWLEDGEMENTS}

This work originates from my $\mathrm{Ph} . \mathrm{D}$. thesis which I defended at Indiana University, Bloomington, U.S.A. in 1996. I would like to thank all members of my dissertation committee, especially Dr. Steven Franks, for guiding me through my graduate studies at IU and the preparation of my dissertation. I would also like to express my graditute to the scholars at the Serbski institut in Budysin. Special thanks go to Dr. Irene Šrak for helping me find native speakers for my fieldwork, and for reading portions of the manuscript, and to Dr. Helmut Faßke for allowing me access to some of his recent data. I would also like to thank Erik for all his support and patience while I was working on the dissertation, and Pat for proofing the book manuscript.

This research was supported in part by an IU International Programs Pre-Dissertation Fellowship, an IU College of Arts and Sciences Summer Research Fellowship, a Wabash College Faculty Development Grant and an American Council of Learned Societies Dissertation Fellowship. All financial help was greatly appreciated and allowed me to expand the project far beyond my original goals.

This book is dedicated to my father, Dr. Siegfried Profe, who always rejoiced in my successes. He would have celebrated the completion of this work.

Eau Claire, Wisconsin, summer 1998 
TABLB OF CONTENTS

ACKNOWLEDGEMENTS

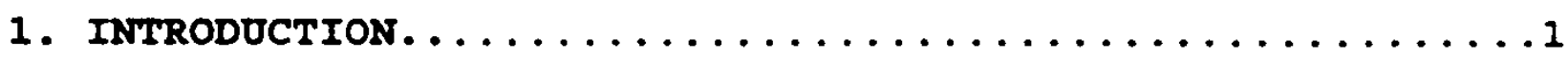

1.1. The issue of null nubjects

1.2. Slavic languages and universal grammar

1.3. Organization

2. NULL SUBJBCTS IN THE GOVERNMENT BINDING FRANEWORK.....8

2.1. Theoretical background

2.2. Are null subjects more than just nothing?

2.3. Development of the pro-drop parameter

2.4. Null-subject diagnostics

3. NULL-SUBJECT CEARACTBRISTICS OF SLAVIC LANGUAGES ....40

3.1. Application of null-subject diagnostics

3.1.1. West Slavic and South Slavic

3.1.2. Russian (East Slavic)

3.2. Why is Russian different?

3.2.1. The intuitive explanation

3.2.2. How to formalize the difference between Russian and West and South Slavic

3.3. Summary

4. IS SORBIAN A PrO-DROP IANGUAGE? $\ldots \ldots \ldots \ldots \ldots \ldots \ldots \ldots$

4.1. The Sorbian population of Germany

4.2. Verbal morphology of Upper Sorbian

4.3. Grammar vs. Reality

4.4. Application of null-subject diagnostics

4.5. Pronouns and purism

4.6. Why is Sorbian not a canonical null-subject language? 4.6.1. Identification and the number of syncretisms

4.6.2. A word order account

4.6.3. Challenges for the identification/licensing framework

4.6.4. The competition model and the loss of pro-drop 
-VII -

4.7. Lower Sorbian

4.8. Summary

5. THE STATUS OP OVERT EXPLETIVES IN CZBCB AND SORBIAN...144 5.1. Licensing/identification and the typology of languages 5.2. Spoken Czech

5.2.1. Syntactic status of overt expletives

5.2.2. Origin and meaning of Czech expletives

5.3. Upper Sorbian

5.3.1. Syntactic status of overt expletives

5.3.2. Historical perspective

5.3.3. Upper Sorbian and German

5.4. Summary

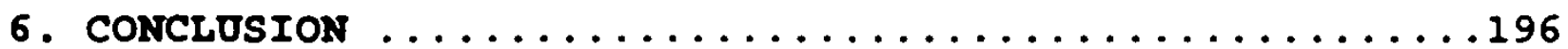

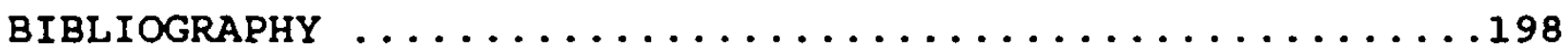




\section{INTRODUCTION}

\subsection{The issue of null subjects}

It is readily apparent that languages vary according to whether an unstressed pronominal subject of a finite clause is lexicalized (English, French) or not (Spanish, Italian). This study derives from and contributes to the large corpus of recent research by generative grammarians which has sought to explain this crosslinguistic variation in the occurrence of null subjects.

In a broader sense this work is part of an even larger tradition since generative syntacticians were certainly not the first to concern themselves with the zero-problem in 1 inguistics. Indeed, the concept of zero-elements (also called null elements or phonologically empty elements) has been previously invoked by many linguists belonging to different schools of linguistics, including those of the French linguist de Saussure and his students, Jakobson and the Prague functionalists, and Bloomfield and the American Structuralists. As a result Meier (1961) was able to devote an entire monograph to the "zéro-Problem in der Linguistik", in which he included a survey of "Zéro-Spezial-Arbeiten" and a survey of the history of this topic in linguistics.

For generative linguists, null subjects have proven to be a fruitful topic of debate ever since Perlmutter's Deep and surface structure constraints in syntax (1971). Since one of the central concerns of the "principles and parameters" model 
of government and binding (GB) theory has been to determine positions in which overt and phonologically empty manifestations of different NP types can occur, defining the precise nature of the crosslinguistic variation in the availability of empty subjects has been of special interest to GB, generating numerous articles and several books, such as Bouchard (1984), Roberge (1990), and Jaeggli and Safir (1989).

Traditionally, Italian has been cited as an example of the canonical null-subject or pro-drop languages which are clearly identifiable as different from canonical overt subject languages, such as English, as illustrated in (1).

$\begin{array}{ll}\text { (1) parlo } & \text { I speak } \\ \text { parli } & \text { you speak } \\ \text { parla } & \text { he speaks } \\ \text { parliamo } & \text { we speak } \\ \text { parlate } & \text { you speak } \\ \text { parlano } & \text { they speak }\end{array}$

Since the Italian inflectional paradigm uniquely distinguishes all person/number combinations, it is intuitively clear, independent from any specific grammatical framework, why Italian can afford to do without overt subject pronouns: The pronominal features (person, number) of a "missing" subject can be recovered unambiguously due to the rich inflectional agreement on the verb. 
However, with the eventual spread of theoretically informed generative studies to more and more languages, it became apparent that the situation is far more complex than expected. It is now clear that the relationship between rich agreement and null subjects is less direct than originally assumed. On the one hand, there are languages like German. which seem to have what we would call rich agreement, but fail to allow referential null subjects, while on the other hand, there are languages like Japanese and Chinese, which are quite capable of omitting subject pronouns, despite their lack of agreement morphology.

Further research revealed that some languages (such as German, Icelandic and Russian) can show mixed behavior with respect to the pro-drop parameter. In German, for instance, referential subjects and quasi-argumental' subjects are not omitted, whereas truly expletive subjects are.

(2) $1 \mathrm{ch} / * 0$ liebe Tiere

'(I) love animals'

(3) draußen regnet $\mathbf{e s / * 0}$ schon wieder 'outside it is raining again'

(4) ich bin froh, daß $0 /$ es getanzt wird

'I am happy that there is dancing going on'

1 As pointed out by Chomsky (1981: 325), quasi-arguments have some properties of true arguments (e.g. control of PRO) and some properties of non-arguments (cannot be replaced by referential NPs) and thus behave differently than truly expletive subjects. 
Thus there is in fact no clearcut division between nullsubject and non-null-subject languages. Despite the longstanding intuition that there is a relationship between richness of agreement and the availability of null subjects in a specific grammar, a definitive and completely accurate characterization of the notion of inflectional richness has yet to be proposed.

\subsection{Slavic languages and universal grammar}

The theoretical parts of this work are conceived within the syntactic framework of GB theory, initiated by Chomsky (1981, 1982) as a development of earlier versions of generative grammar and further refined during the past decade. The crucial hypothesis adopted by Chomskian syntacticians is that a large part of a speaker's knowledge about language is innate. All humans are endowed with the same universal grammar (UG), which consists of a set of absolute universals and principles, which do not vary from one language to the next, and a range of parameterized principles whose actual values have to be fixed during childhood language acquisition upon exposure to language. Thus, while the language-specific properties themselves are not fully determined by UG, the available options are. The grammar of a specific language boils down to a particular set of values for the parameters. This theory, for apparent reasons, is often referred to in the relevant literature as the "principles and parameters" theory and we shall use this term synonymously with "government and binding". 
Until fairly recently the Slavic languages received relatively little attention within GB theory. This is actually quite surprising, considering that these 14 closely related languages ${ }^{2}$ show interesting syntactic differences which can provide Chomskian syntacticians with an ideal pool of data to test their theories of universal principles and potential parametric variation. Certainly, from the perspective of nullsubject phenomena, which are the focus of this work, the Slavic languages are quite diverse.

The identification of particular problems in the slavic languages may thus indicate modifications which must be made to current theories in general. Since it is a basic tenet of UG that any analysis proposed for some language(s) should be able to explain data of other languages and accommodate crosslinguistic variation, it follows that the investigation of data from "overlooked" languages is often crucial in proving or disproving the general validity of theoretical assumptions.

In this context perhaps the most neglected of the modern Slavic languages is Sorbian, also referred to as Lusatian and Wendish, which belongs to the West slavic language family. Since it is one of the most complex slavic languages with regard to null subjects, it is a major focus of this present

East Slavic: Russian, Ukrainian, Belorussian West Slavic: Polish, Kashubian, Upper Sorbian. Lower Sorbian, Czech, Slovak

South Slavic: Serbian, Croatian, Slovene, Macedonian, Bulgarian

There is some disagreement among linguists whether Kashubian and Polish, and Serbian and Croatian are separate languages. 
work. Sorbian is generally accepted to have split into two different literary languages, identified as Upper and Lower Sorbian, which are spoken by a very small minority in and around the cities of Bautzen and Cottbus in Eastern Germany. The total assimilation of this slavic society into the vastly greater German one which surrounds it also plays a role in this study, culturally as well as linguistically.

The rapid decrease in the number of native speakers of Sorbian in recent decades (about 22.500 remain) has been accelerated by the economic and social disruption brought about by the collapse of East Germany in 1989. It is hoped that this current research will help to slow this decline by increasing awareness, and contributing to the (re) introduction of the Sorbian languages into academic discussion. Ironically, the same political changes which threaten the survival of the Sorbian language and culture have also improved access to native speakers of Sorbian by Western linguists.

\subsection{Organization}

This work is divided into four main chapters, the first of which, Chapter 2 , sets out to establish a theoretical background. The licensing and identification approach to null subjects is summarized and a set of three diagnostics introduced which can be used to decide whether or not a language has all the properties of a canonical null-subject language. 
In Chapter 3, these diagnostics are applied to slavic in general, identifying a split between East slavic on the one hand, and West and South Slavic on the other. This is followed by a section which discusses why the Slavic languages are divided along these lines.

Chapters 4 and 5 are devoted to Upper Sorbian and Czech. Both chapters present and discuss linguistic data which seem to challenge the licensing/identification framework. This begins with Upper Sorbian which provides a telling counterexample to the long accepted intuition that the explicitness of verbal morphology and occurrence of null-pronominal subjects are directly related. A broad examination of contemporary and early texts reveals a surprisingly high level of overt pronoun use, which makes Sorbian an exception among the West Slavic languages. Chapter 5 focuses on the comparison and analysis of the occurrence of overt expletive subjects in Czech and Upper Sorbian. Czech generally omits unstressed pronominal subjects. This is expected, since Czech verb forms uniquely distinguish the different person/number combinations, very much like in the Italian example above. However, overt non-referential pronouns occur frequently in spoken Czech, which has generally been assumed impossible for languages which omit referential subjects. The analysis of Czech expletive subjects is followed by a discussion of overt non-referential pronouns in Upper Sorbian. 


\section{NOLL SUBJECTS IN THB GOVBRAMIENT BINDING FRAYEFORR}

\subsection{Theoretical background}

GB theory describes knowledge of language as a highly structured theory of UG which is composed of an interrelated set of six modular subtheories. These are enumerated by Chomsky (1981: 5) as bounding theory, government theory, theta-theory, binding theory, Case theory and control theory. These subsystems, in turn, are made up of general principles and parameters whose potential value settings vary within clearly defined limits from one language to another. GB is also modular in the sense that it assumes four different levels of representation, known as $\mathrm{D}$ (eep)-structure, S(urface)-structure, phonetic form (PF) and logical form (LF). These different levels of representation are related to each other by a transformational component which contains the rule Move- $\alpha$, which, in effect, allows anything to move anywhere. Various general principles regulate the mapping from one level to another by determining which movements are well-formed and which are not.' One important constraint on the relation between syntactic representations is the structure-preserving

1 There are central structural concepts which are not confined to any particular subtheory, most notably the notions of "c-command" and "government". Here, we assume the following definitions (simplified from Chomsky, 1986): $C$-command (extended to include $m$-command): Node A c-commands node $B$ iff $A$ does not dominate $B$ and every $X$ that dominates $A$ also dominates $B$.

$A$ governs $B$ iff $A$ C-commands $B$ and no barrier intervenes between $A$ and $B$. 
principle, derived from the work of Emonds (1976), according to which movement operations must not destroy existing structures. This means that those structures established at Dstructure must be preserved at $s$-structure. It follows that when a given element is moved from its extraction-site to its landing-site it cannot simply disappear from its original site "without a trace". Hence, whenever an element is moved, a coindexed, empty element called a trace remains in the moved element's original position.

Theory-internal reasons force this syntactic framework to assume the existence of non-overt, but structurally present categories. Two principles, the theta-criterion and the projection principle, which define how the properties of lexical entries are projected onto syntax, are especially crucial in this respect. The theta-criterion specifies that each argument bears one and only one theta-role and that each thetarole is assigned to one and only one argument. According to the projection principle, the specifications for each lexical item given in its entry in the lexicon have to be met at all levels of syntactic representation. In other words, the oneto-one pairing between the thematic roles and arguments of a verb's predicate-argument structure required by the thetacriterion has to remain consistent on all levels of derivation (D-structure, S-structure, and LF). The projection principle and the theta-criterion determine whether an NP has to be present in a syntactic representation. However, a structurally 
required NP can be manifested either as phonologically realized (overt) or non-realized (null). The latter is called an empty category. The various sub-theories of $\mathrm{GB}$ interact to determine whether the NP is lexical or not, and what type of NP appears in any given position. Certain empty categories can only appear in certain structural positions, which is reflected in the formulation of licensing requirements for empty categories. However, the exact formulation of such licensing conditions is far from being uniformly agreed upon. Furthermore, the content of those "missing" elements has to be identifiable. The position of traces, for instance, is formally licensed by the empty category principle, " while their content is determined by their antecedent. An interesting issue in this context is whether formal licensing of the occurrence and the identification of the content of an empty category are achieved by one and the same or two distinct operations. We shall return to this question in section 2.3 .

The typology of empty categories as developed by Chomsky (1982: 78-89) mirrors that of overt categories. The module of the grammar regulating the interpretation of NPs is the bind-

2 Traces must be governed in a special way in order to occur in certain positions: They must be properly governed.

Bmpty category principle:

Traces must be properly governed. A properly governs $B$ iff $A$ theta-governs $B$ or $A$ antecedent-governs $B$. (Chomsky, 1986: 17). $A$ head $A$ theta-governs $B$ if it governs and theta-marks $B$. $A$ maximal projection $A$ antecedent-governs $B$ if $A$ and $B$ are coindexed and $A$ governs $B$. 
ing theory. Chomsky proposes that the three overt NP-types, anaphor, pronoun and R-expression, should be intexpreted as composed of two features: [tanaphoric] and [tpronominal].$^{3}$ Depending on its feature matrices, the NP is subject to different principles of the binding theory. An NP-type which is subject to principle $A$ of the binding theory has the feature [+anaphoric] and consequently has to be bound in its governing category. A category which is subject to principle B of the binding theory has the feature [+pronominal] and therefore has to be free in its governing category. Chomsky further assumes that the typology of empty categories can also be derived from the possible combinations of [tanaphoric] and [tpronominal]. The inventory of overt and empty NPs is illustrated in Table 1 .

Table 1: Classification of NPs

$\begin{array}{ccll}\text { Anaphoric } & \text { Pronominal } & \text { Overt NPs } & \text { Empty NPs } \\ + & - & \text { anaphors } & \text { NP-traces } \\ - & + & \text { pronouns } & \text { pro } \\ + & + & \text { excluded } & \text { PRO } \\ - & - & \text { R-expression } & \text { Wh-traces } \\ \text { (variables) }\end{array}$

3 This is analogous to the representation of syntactic categories such as $N, V, P$ and $A$ by feature matrices rather than primitives. 
According to Table 1, anaphors and NP-traces are subject to principle $A$ of the binding theory and must be bound within their governing category. Pronouns and pro have to be free within their governing category, and referring expressions and variables are subject to principle $C$, that is they must not be bound anywhere. The features proposed for the NP-types are binary, and, in the ideal case, we expect all four combinations to occur. The inventory of empty categories supports this expectation. However, there are only three overt NPtypes. The occurrence of an overt NP-type with the feature composition [+anaphoric,+pronominal] is ruled out by independent principles of UG.`

The different overt and null elements are exemplified in the following sentences. The Slavic examples are from Russian unless otherwise indicated:

4 An element which is [tanaphor] must be bound within its governing category, in keeping with principle $A$ of the binding theory. An element which is [+pronominal] must be free in its governing category in keeping with principle $B$ of the binding theory. NPs with the features [+anaphoric, +pronominal] are thus subject to contradictory requirements. The only way for an element to fulfill both principle $A$ and $B$ at the same time is to lack a governing category. If there is no governing category, then neither principle $A$ nor principle $B$ apply, because the domain in which the element has to be both free and bound is not defined. This can be fulfilled under the condition that the NP lacks a governor. However, an overt NP that lacks a governor cannot be case-marked, under the assumption that case marking requires government, and hence will be ruled out by virtue of the case filter, according to which all overt NPs have to be case marked. As an empty category. PRO is not subject to the case filter and the absence of a governor is not problematic. Furthermore, due to its feature composition PRO is only admitted in ungoverned positions. This proposition is referred to in the literature as the "PRO theorem". 
(1) [+anaphoric, -pronominal]

Overt: anaphor

Ivan, ljubit tol'ko sebja

'John, loves only himself $f_{i}$

Empty: NP-trace

domi byl postroen $t_{1}$

' the house, was built $t_{i}$ '

(2) [-anaphoric, +pronominal]

Overt: pronoun

Ivan, nenavidet ego ${ }^{\prime}$;

'John, hates himpio'

Empty: pro

pro miluju Mariu

[CZ]

'(I) love Mary'

(3) [+anaphoric, +pronominal]

Overt: excluded

Empty: PRO

on xoCet PRo Zenit'sja na Marii

'he wants [PRO to marry Mary]'

(4) [-anaphoric,-pronominal]

Overt: $R$-expression

on $n_{i}$ dumal, tto Ivan $_{y^{\prime} ;}$ pobedil $v$ zabege

' he $e_{i}$ thought that John $y_{\gamma^{\circ} ;}$ won the race'

Empty: variable

$k_{k o g o}$ vy priglasili $t_{i}$

' whom ${ }^{1}$ did you invite $t_{i}$ ' 
A number of issues connected with the types of empty categories described above remain controversial, although the study of empty categories with respect to their type, distribution and contents has become a very popular topic within GB.

\subsection{Are null subjects more than just nothing?}

Let us review some of the empirical and theory-internal reasons which support the assumption that empty subjects of both tensed and infinitival clauses are real in the sense that they are structurally present in a representation. Following Chomsky (1986) I assume that X-bar theory, including the endocentricity requirement for phrases, applies to both lexical and non-lexical (functional) categories. The clausal category traditionally labeled $S$ is reinterpreted as the maximal projection of $I$, where $I=I N F L$, and the category $S^{\prime}$ is reinterpreted as the maximal projection of $C$, where $C=$ complementizer.

(5) S

Comp

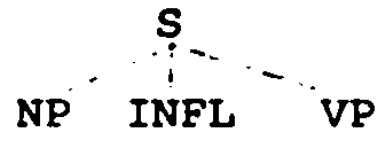

(6)

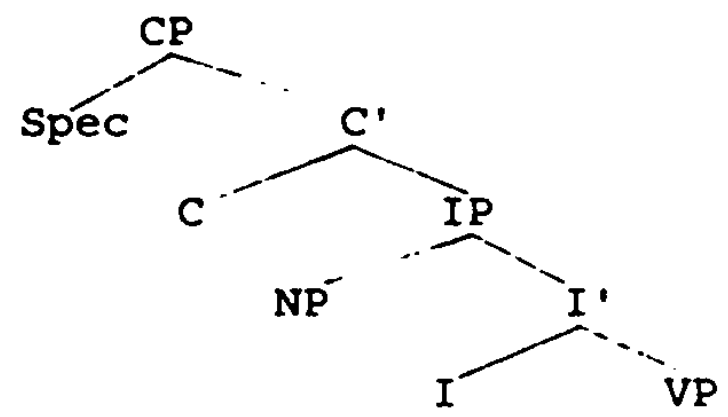


Unless otherwise stated, I will assume that structural subjects are base-generated in and occupy the specifier position of IP [NP, IP].S

In the following $I$ argue against $(7 a)$ and in favor of structure (7b) for all sentences, even if the subject is not phonologically realized:

(7) a.

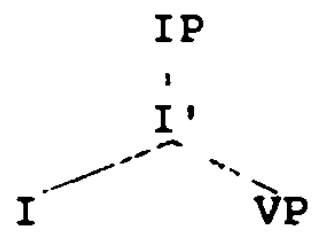

b.

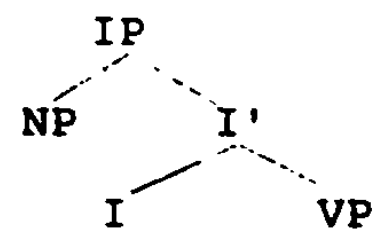

In the sentences below it is obvious that even in the absence of an overt subject its presence is felt implicitly and its content can (and must) be recovered to ensure a complete statement. (Here and in later examples I shall use 0 to indicate the presence of a generic empty category)

(8) e biju ho [Cz]

'(I) beat him'

(9) on xocet [e bit' Ivana] [Ru]

'he wants to hit Ivan'

The verb 'to hit' takes two arguments: an external argument which receives the theta-role of agent, and an internal argu-

s An alternative proposal which has been gaining ground in the recent literature is the so-called VP-internal subject hypothesis. Sportiche (1988) proposes that all subjects are base-generated in [Spec,VP] position, so that NPs in [Spec, IP] are derived subjects. I shall return to this hypothesis in subsequent chapters. 
ment which is assigned the role of patient. It follows from the theta-criterion in conjunction with the projection principle that a sentence with a verb which assigns an external theta-role must have a structural subject at any level of the representation.

Within GB, the missing subjects in (8) and (9) represent two fundamentally different types of empty categories, although they have in common the fact that they are base-generated, as opposed to the [-pronominal] empty categories, which represent traces of movement. The non-overt subject of an infinitive is PRO, while missing subjects of tensed clauses are pro. In contrast to PRO, which must be ungoverned according to the PRO-theorem, pro is found in governed position since it alternates with overt NPs. It is generally assumed that nominative case is assigned to an NP in the specifier position of IP through government by a finite [+tense, +AGR] INFL. A non-finite [-tense,-AGR] INFL on the other hand, is not a governing head, leaving [Spec,IP] ungoverned so that PRo occurs in that position.

(10) a.

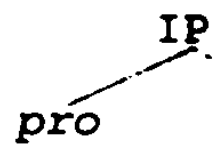

I

+ tenes

$+\mathbf{A G R}$ b.

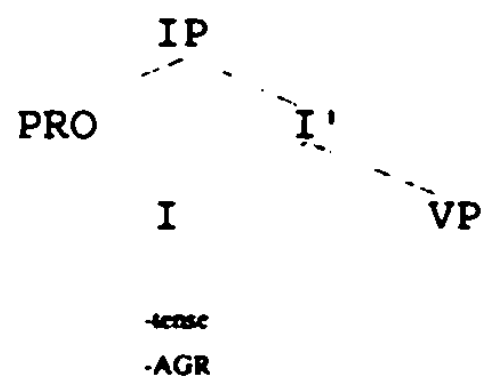


The central concern for this study is the different manifestations of subjects of finite clauses (as pro or as lexicalized pronoun) in Slavic languages, with a special focus on Russian. Czech and Upper Sorbian.

More evidence supporting the structural presence of a subject position can be drawn from the modules of binding and control theories. Consider the following Czech sentences and the binding facts they demonstrate:
(11) e miluje sebe
' $\left(h_{i}\right)$ loves himself $f_{i j}$ '
(12) e miluje ho
' (he $\left.e_{i}\right)$ loves him.ijj
(13) e miluje Petra
' $\left(h_{i}\right)$ loves Peter ${ }_{a_{i j}}$ '

These facts follow immediately from principles $A, B$ and $C$ of the binding theory, if we assume the presence of an (empty) element in [NP,IP] position.

The following examples show that the theta-criterion alone cannot justify the existence of all empty subject NPs:

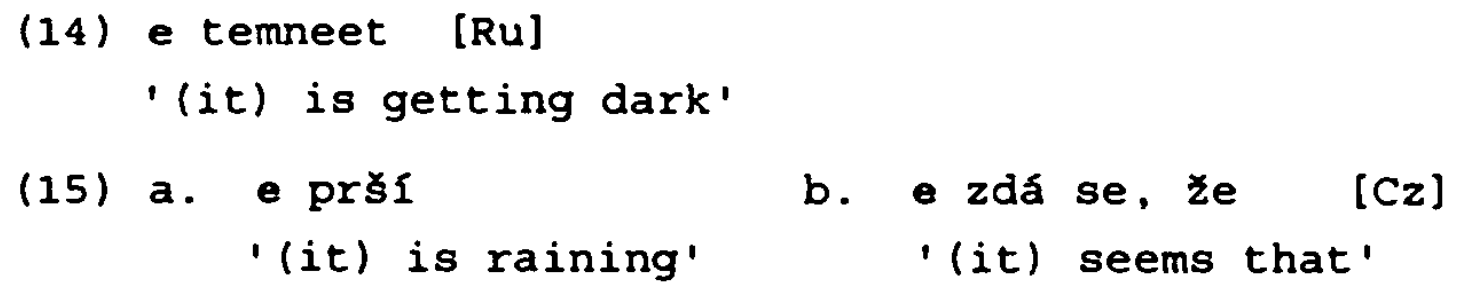

The verbs in (14) and (15) do not assign any obvious external theta-role to the NP in subject position. ${ }^{6}$ However, there is

6 According to Chomsky (1981: 325), subjects of socalled weather-verbs have a "quasi-argumental" status. For some languages such a distinction of non-referential subjects 
another (admittedly somewhat dubious) principle within GB, known as the extended projection principle (EPP), which stipulates that all sentences must have a subject, regardless of their argument structure. Here I follow the traditional GB analysis according to which in the sentences above a nullexpletive subject occupies the structural subject position. Similarly, in overt subject languages, such as English, the EPP accounts for the presence of the expletive it or there in subject position.

(16) */1t is nice that you came

However, some researchers, including Babby (1989), reject the EPP and instead postulate the existence of truly subjectless sentences, i.e. sentences without a structural subject position. Of course, the existence of null expletives raises obvious empirical problems. Why should they exist, lafter all they are invisible and have no meaning), and how do we know and learn that they exist? One might simply want to claim that the obligatory structural presence of a subject position is part of UG. Chomsky (1982: 10) does exactly that when he writes about the EPP:

may be crucial. In German, for instance, quasi-argumental subjects, as in (ii), and non-argumental subjects, as in (i). behave differently: The latter must remain lexically unexpressed, while the former must be overt.

(i) ich gehe nicht raus, weil e/*es dort getanzt wird 'I don't go outside because there is dancing going on'

(ii) ich gehe nicht raus, weil es/*e regnet

'I don't go outside because it is raining' 
We may think of it as a general principle governing D-structures, hence also governing structures derived from them. There are good reasons, which I will not elaborate here to assume that the same is true of languages that appear to allow a "missing subject" (e.g. Romance languages other than French).

It is interesting that other theories also postulate the existence of such covert expletives due to theory internal requirements, such as Relational Grammar's "Final-One Law". Be this as it may, while currently we cannot really prove that these empty elements are structurally present, it is at least as impossible to prove that they do not exist, due to their special "no meaning" and "no lexical material" property.

\subsection{Development of the pro-drop parameter}

Languages that leave a pronominal subject unexpressed traditionally are called pro-drop languages, since they seem to "drop" the subject pronoun. This term stems from earlier analyses and reveals that the phenomenon of null subjects was originally interpreted as a deletion rule (Perlmutter 1971).' Thus, from the perspective of the current syntactic framework the term "pro-drop" is obsolete, since the deletion of a subject in the course of a derivation would contradict several

7 In earlier accounts it was claimed that the prodrop phenomenon correlated to a host of other syntactic properties, such as free subject inversion and apparent violations of the that-trace filter, suggesting that a single grammatical property might account for a whole complex of contrasts between null-subject and overt-subject languages (cf. Perlmutter 1971; Taraldsen 1978; Jaeggli 1982; Rizzi 1982). This idea was later challenged by Safir (1985), among others. 
theoretical assumptions, most notably the theta-criterion and structure-preserving principle. However, in keeping with the current literature on the topic, we shall maintain the label pro-drop parameter here. The development of the pro-drop parameter over the years reflects one of the most important tendencies of GB theory in general: a movement away from specific rules and towards general principles.

Since Taraldsen (1978), the pro-drop parameter has been associated with the phenomenon of "rich inflection" which can determine the grammatical features of a missing subject. He analyzed null subjects as base generated anaphoric NPs, rather than as the result of "pronoun deletion". According to him. empty subjects are null anaphors which do not violate Chomsky's nominative island constraint on nominative anaphors due to the fact that the null-subject NP and the finite verb are coindexed. Thus, in languages with rich agreement the subject-verb agreement can bind a null-subject NP, thereby rendering the NIC inoperative. Taraldsen's analysis can be rephrased within a theory which now contains the ECP instead of the NIC. A subject pronoun can be omitted if $A G R$ is rich enough to properly govern the subject position.

As far as determining the type of the empty category in the subject position of tensed clauses, the investigation of null subjects predates the discovery of pro. Chomsky (1981) native anaphors have to be bound within their clause. 
still assumes that there are only two types of empty categories, PRO and traces, and that the missing subject of a tensed clause is of the PRO type. As we saw earlier, PRO is characterized within the GB framework as a pronominal anaphor, and under that assumption it has to be ungoverned. Chomsky (1981) then has to stipulate that in null-subject languages the subject of tensed clauses may be ungoverned at s-structure due to movement of INFL into VP in the syntax. This analysis contradicts those by Taraldsen (1978) and Rizzi (1982), where the empty subject is said to be licensed precisely under government by INFL. It is not until his 1982 monograph that Chomsky posits the existence of the empty pronominal category pro, in the process of developing the full typology of empty elements.

Most approaches since Taraldsen have identified the crucial property of null-subject languages in the inflectional element. usually relying on the notion of richness in one way or another. One of the earliest and most influential GB accounts of the null-subject parameter is given by Rizzi (1982). Perhaps the most important aspect of Rizzi's paper is his argument that what had been considered a monolithic parameter of UG should really be split into two autonomous yet connected subparameters. His argument is based on the different distributional restrictions of referential and "dummy" empty subjects in Italian. The first subparameter specifies whether a 
language licenses null subjects (INFL [+pronominal]). This property is not directly related to the morphological richness of the language. The second subparameter, however, is directly related to morphological richness and determines whether INFL can recover the referential content of an empty subject (INFL [+referential]. These two parameters predict four theoretically possible language types (Rizzi 1982: 143):

$\begin{array}{llll}1 & 2 & 3 & 4 \\ + \text { pron } & + \text { pron } & \text {-pron } & \text {-pron } \\ + \text { ref } & \text {-ref } & \text { tref } & \text {-pron }\end{array}$

Language type 1 is represented by Italian, a canonical prodrop language. Type 4 is a canonical non-null-subject language like English. According to Rizzi, combination 3 is excluded for "intrinsic reasons". A pronominal INFL can be referential only if its grammatical features of agreement are structured beyond a certain richness threshold. In other words, an inflection cannot be [+ref] if it is not [+pron] . Type 2 represents a language type which has phonetically null dummy subjects but overt referential subjects. Rizzi (1982) points out that this language type seems to exist, however, he does not go into much detail. ${ }^{10}$

10 Rizzi (1982: 143) cites the northern Italian dialect of Padua as a potential example for this parameter combination. Later research provided more evidence for this "mixed" language type (e.g. Russian, German, Icelandic). 
For any analysis of empty elements, null subjects included, there are two questions which need to be answered: What formally licenses them? How is their content (the personnumber features of the missing subject) determined? Early approaches make no clear distinction between licensing and identification. Even for Rizzi (1982), who in principle argues in favor of a split of the pro-drop parameter into licensing and identification, it is INFL which licenses the null subject of a tensed clause, and it is the spelling out of the pronominal features of INFL which allows identification of the missing subject.

Early work on the topic of null subjects concentrated almost exclusively on rich agreement languages, and thus it was supposed to be rich agreement alone which made pro possible. It was not until other languages were included in the research that it became apparent that the situation was far more complex.

Rizzi (1986) criticizes the standard approach under which pro is restricted to occur only in the context of rich agreement and which unifies the formal licensing of pro and the identification of its content into one and the same operation via government by a strong Agr. He points out that in the broader context of null elements such an assumption is surprising, since for traces and PRO the licensing conditions and the recovery operations are kept separate. Formal licensing appears to involve some kind of government relation, while the 
recovery procedure involves some kind of binding relation. Based on the occurrence of null objects (pro) in Italian despite the lack of object agreement, Rizzi (1986) argues in favor of divorcing the licensing conditions for pro from the inflectional system. He proposes what has become known as the pro-module, made up of two main independent principles (Rizzi $1986: 521,524):$

(17) Pro-module:

A: pro is licensed if case-marked by $x_{y}^{0}$

B: pro has the grammatical specification of the features on $x$ coindexed with it

The class of licensing heads can vary from language to language and seems in a sense arbitrary. In Italian, for instance, INFL is a licensing head for pro in subject position. and $V$ is a licensing head for pro in object position."

Jaeggli and Safir (1989) maintain the sharp distinction between licensing and identification, however, they present a novel treatment of the two processes. Chinese and Japanese. both null-subject languages which completely lack any sort of agreement, show clearly that the licensing criterion cannot be exclusively associated with rich morphology. Jaeggli and Safir's generalization is that null subjects seem to be licensed in languages with either very rich agreement or no

" Rizzi's (1986) study implies that pro is not restricted to subject position of tensed clauses. However, null subjects remain the main focus of this study. 
agreement at all, and they formulate morphological uniformity as a licensing criterion. ${ }^{12}$ An inflectional paradigm of a language is morphologically uniform if it has either only underived inflectional forms or only derived inflectional forms. If some forms of a paradigm are divisible into stem+affix and other forms of the same paradigm are bare stems, then the paradigm is mixed, and no null subjects are licensed. Under this model, the licensing conditions do not provide a mechanism to recover the referential value of a null pronoun. A separate identification mechanism is necessary to determine the content of a thematic NP. According to Jaeggli and Safir, identification can come about in a couple of different ways. However, they are fairly vague on formulating the precise conditions for identification. Identification can happen locally by agreement if the category containing AGR case-governs the empty category. ${ }^{13}$ Thus, in languages like

12 The discovery that the phenomenon of "pro-drop" can occur when there is a rich agreement element or when there is no agreement at all actually goes back to Huang (1984).

13 It has been argued that in V-2 languages, such as German or Icelandic, the nominative case is assigned by Tense, which is located in COMP (C of CP), while AGR is located in INFL ( I of IP). Under the requirement that identification by AGR can only happen if the category containing AGR is case-governing the empty subject, we now have an account for the lack of thematic null subjects in German and Icelandic. Both languages have morphologically uniform paradigms, and hence license null subjects, however, identification is blocked due to the distribution of Tense and AGR in separate nodes. More support for this approach comes from West Flemish (cf. Bennis and Haegemann (1984), which has complementizers which are inflected for person and number and indeed allows null thematic subjects. This is, then, an instance in which both Tense and Agr are part of the same governing node, and identification can take place. 
Spanish or Italian, the agreement affixes with the relevant phi-features act as identifiers. For languages which uniformly lack agreement, such as Chinese and Japanese, Jaeggli and Safir essentially follow Huang's (1984) analysis. In these languages, a null subject can be identified either by a ccommanding nominal in the matrix clause or by a (null) topic. ${ }^{4}$ Although it is not clear per se why something like the morphological uniformity criterion should be operative in

14 Only in the first instance should we really speak of pro. Consequently, the occurrence of genuine null subjects in Chinese and Japanese is in fact quite restricted. Consider the following Chinese examples (Huang 1984):

Speaker A: Zhangsan kanjian Lisi le ma? 'did Zhangsan see Lisi'

Speaker B: (i) e kanjian ta le

'(he) saw him'

(ii) Zhangsan xiwang le keyi kanjian Lisi ' Zh. hopes (he) can see Lisi'

In Huang's analysis, the empty element in (i) can only be a variable bound to a zero topic. In "rich" agreement languages which license pro the empty element in the same position could be identified by Agr. This type of identification is unavailable in Chinese. The empty category in (ii) may have dual status. Its reference can be determined by an "outside" discourse topic (variable reading) distinct from zhangsan or it can be fixed via coindexation with the NP Zhangsan in the matrix clause (pronominal reading).

One might object that even in a pro-drop language the reference of an empty third-person subject, such as in (i), seems to depend on the discourse. The difference, however, is the following: The interpretation of $3 \mathrm{rd}$ person pro could be understood as a two-step process. First, the pronominal features under AGR determine the pronominal content (person, number, gender) of the empty pronoun. This is what I refer to as identification of the content of pro. Once that is done, the identified pro behaves like a "normal" pronoun, being interpreted according to principle $B$ of the binding theory. During that part of the interpretation operation a pronoun may be freely coindexed with NPs outside their governing domain. 
natural language (cf. Speas (1994) below for a possible interpretation), the licensing and identification theory developed by Jaeggli and Safir fits well into the general context of empty categories. Similar to Rizzi's (1986) pro-module, it keeps licensing and recovery of content separate. Licensing is a purely formal criterion, while identification is a more contentful criterion, referring to the availability of some mechanism to retrieve the essential grammatical information left phonologically unexpressed in order to provide the empty category with some content. For traces, this division of labor is exemplified by the ECP as the licensing condition, and antecedent government as the identification operation. The empty category PRO is Iimited to occur in ungoverned contexts, and derives its content from an antecedent which is determined through control theory.

Originally it was assumed that there were only two Ianguage types with respect to the pro-drop parameter: Null-subject languages (Italian type) and non-NSL (English type). However, as discussed earlier in this chapter, Rizzi (1982) predicted the existence of a "mixed" language type. German, is one such semi-pro-drop language. It does not omit thematic subject pronouns, as shown in (18), though it does permit (requires) expletive subjects to be null, as shown in (19).15

15 In fact, there are probably two types of semi-prodrop languages, namely those which allow only non-argumental subjects (excluding subjects of so-called weather verbs which are quasi-argumental according to Chomsky 1981), for instance German, and those that allow both non-argumental and quasi- 
(18) er/*pro tanzt gern

'he likes to dance'

(19) P geht ins Dorf, weil pro/*es dort getanzt wird 'P goes to the village, because pro there is dancing'

A licensing/identification approach à la Jaeggli/Safir predicts the difference between the German type (semi-prodrop) and Italian type (full pro-drop). It makes sense that within such a scheme, empty categories which lack semantic content need to meet only the licensing criterion, since there is no content which needs to be recovered via identification. Expletive subjects, by definition, lack any semantic content, and therefore only need to be licensed. In such a system then, the distribution of null-subject types in German can be understood as a result of formally licensing but not identifying null subjects.

The licensing/identification theory might be understood as breaking up the originally monolithic pro-drop parameter into two distinct parameters, which can be paraphrased as a "Null-Referential-Pronoun" (NR) parameter and a "Null-Exple-

argumental subjects, for instance Icelandic and Yiddish. Unless otherwise stated, for our purposes both non-argumental and quasi-argumental subjects are subsumed under the term "expletives". Rizzi (1986: 541) lists the following possibilities :

a: no occurrence of pro

b: pro=non-argument (German)

c: prosnon-argument and quasi-argument (Yiddish, Icelandic)

$d$ : pro=non-argument, quasi-argument, and referential argument (Italian)

Compare the following examples from Icelandic and German:

(i) hefur pro rignid 'has (it) rained' (ii) hat es/^pro geregnet 'has it rained'

Thas it Mairtina Lindseth - 9783954790661 
tive" (NE) parameter. However, as already implied in Rizzi (1982), these two parameters are not completely independent, i.e. not all four theoretically possible combinations of the two binary parameters should actually exist. ${ }^{16}$ A combination of $[+N R,-N E]$, that is a language with null referential and overt expletives, is unexpected. Expletives by definition lack any referential function, so the only reason for their occurrence must be that a language does not license null subjects at all. In other words, it is much easier for an expletive to be null than for a referential pronoun to be null, since there is no pronominal content which must be recovered. ${ }^{17}$

There are two main problems with the licensing condition as formulated by Rizzi (1986) and the morphological uniformity hypothesis: First, neither encodes the longstanding intuition that there is some sort of connection between rich agreement and the occurrence of null subjects, and second, it is not clear why languages like Italian and Japanese pattern together with respect to null-subject phenomena (if they really do). Although the remainder of this study will focus on the applicability of the licensing/identification approach to slavic, it is worth summarizing a recent proposal by speas (1994)

See pages 22-23 for a discussion of Rizzi (1982).

17 Within this framework it makes no sense to talk about identification without licensing, since, if null subjects in some language were identified without being Iicensed, they still could not exist, so that the fact that they were identified would have no consequencesedindseth-9783954790661 
which attempts to remedy these shortcomings. As theoretical background, Speas assumes familiarity with Pollock's (1989) split INFL hypothesis according to which INFL is decomposed into (at least) two separate functional heads $A G R$ and $T$, each with its own phrasal projection. This yields the clause structure in $(20 b) .18$

(20a)

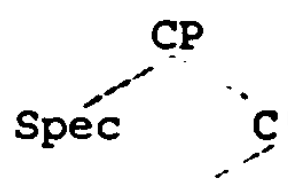

C

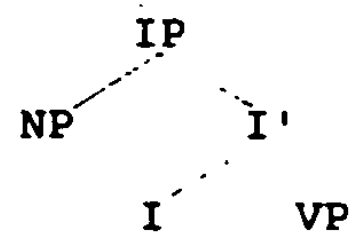

(20b)

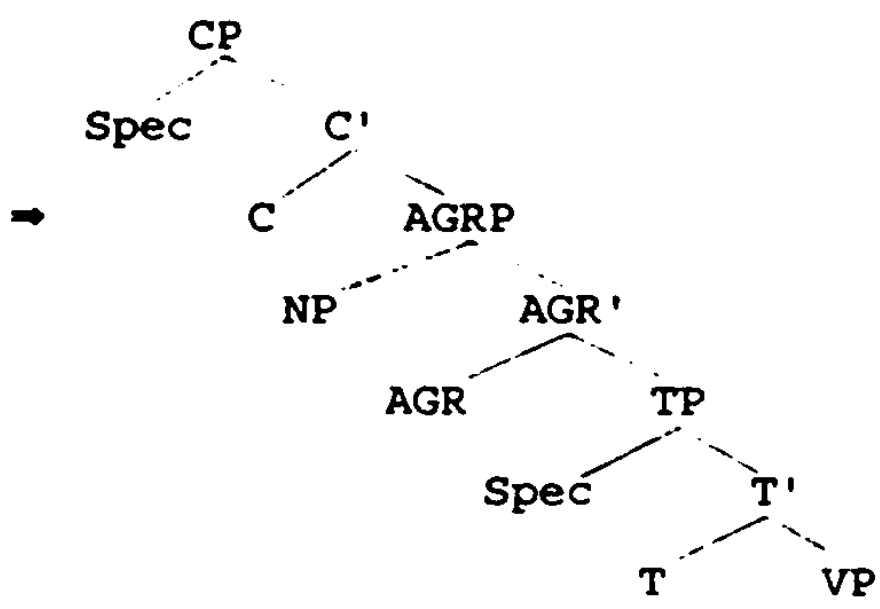

Speas's (1994) proposal aims at explaining Jaeggli and Safir's generalization. Her claim is that the null-subject parameter follows directly from the principle of economy, according to which a projection XP can be projected only if it has content. A node has content iff it dominates a distinct phonological matrix or a distinct semantic matrix. Null arguments occur wherever general principles of economy permit them,

18 I am noncommittal as to the respective position of AGRP and TP, since this has no bearing on the current study. In fact their position might be subject to cross-linguistic variation. The theory of functional projections has received much attention recently, and several other functional projections have been postulated, such as Negation Phrase. Focus Phrase and Determiner Phrase. 
and no special licensing conditions on pro are necessary. Adapting a proposal by Rohrbacher (1995), Speas proposes that in languages with "strong" agreement, each agreement morpheme has its own lexical entry, while in languages with "weak" agreement, the morphemes do not have independent entries. Verbs in weak agreement languages are listed in the lexicon in verbal paradigms. According to Rohrbacher (1995: 356) "strong" agreement, and therefore lexically listed affixes, are found only in those languages which meet the following conditions.

(21) Conditions for lexically listed affixes:

Agrs is a referential category with lexically listed affixes in exactly those languages where regular subject-verb agreement minimally distinctively marks all referential Agrs-features such that in at least one number of one tense, the person features [1st] and [2nd] are distinctively marked.

The functional head AGR has no semantic content. Therefore, if projected it must have phonetic content. In languages with strong agreement, an agreement morpheme heads its own functional projection AGRP. Such an AGRP has content without its spec position being filled by an overt NP. In weak AGR languages, on the other hand, the affix is base-generated on the verb, and so [Spec, AGRP] has to be filled in order to give Agrp content. The former situation accounts for nullsubject languages, the latter for overt subject languages. The principle of economy of derivation also accounts for the Asian null-subject type. Speas suggests that the AGRP projection is necessary only in languages with some sort of agree- 
ment. In languages with no agreement whatsoever, there is no AGRP at any level, therefore the language has null subjects since nothing forces movement into the specifier of AGRP. ${ }^{19}$ For Speas, there is no null-subject parameter per se; instead, null-subject properties of a language are accounted for by an AGR strength parameter coupled with general principles of economy of representation.

\subsection{Null-subject diagnostics}

Ideally, we would have only to look at a sentence involving a pronominal subject in order to determine whether or not a particular language belongs to the null-subject type. However, many (if not all) languages can omit various elements, including subjects, in various styles of discourse. English certainly should not be analyzed as a null-subject language. Nevertheless we find English sentences without overt subjects. for instance when recounting a sequence of events in "diary" style or in certain questions.

(22) a. Woke up. Fell out of Bed. Dragged a comb across my head.

b. Got milk?

Similarly, in German a pronoun can be dropped under certain contextual conditions, provided it occupies the initial

19 It is not clear whether it makes sense to speak of "null subjects" in this context at all, since no structural subject position [Spec, AGRP] is available. 
position in a root clause, or, in other words, the [Spec, CP] position (cf. Ross 1982 as cited in Huang 1984: 555/56).

(23) A: Weißt du schon, daß Peter wieder zurück ist? 'do you know already that $P$. is back again'

B: Ja, ja. e Hab ihn schon gesehen.

'yes,yes. e have already seen him'

The discourse related omissibility of elements, called ellipsis, varies from language to language, and defining the exact conditions under which such "loss" of lexical material can happen lies outside the scope of this work. ${ }^{20}$ In some languages, however, including Russian, missing subjects due to ellipsis can occur in such a wide range of conditions that it becomes difficult to differentiate between genuine pro-drop and ellipsis. ${ }^{23}$

It follows that one cannot readily determine the status of missing subjects in a language, and it has been suggested that we should instead rely on a set of syntactic tests that can be used as diagnostics of pro and therefore the null-sub-

20 There are several interesting questions which I do not plan to discuss here: Should we posit an empty category in the place of the deleted element? If so, which type of empty category should be posited? For a very good discussion of the issues involved see Huang (1984). He analyzes the missing pronoun as a variable in argument position bound by a zero topic, i.e. referring to the discourse topic. The zero topic in turn is discourse-bound to the initial topic of a topic chain. Huang clearly differentiates genuine zero pronouns and variables bound by zero topics. He proposes the existence of two independent parameters: [tzero-topic] and [tpro-drop]. with four logically possible types of language.

21 For a more detailed discussion see chapter 3 . 
ject status of a particular language (Lindseth and Franks (1994); Franks (1994)).

Typical characteristics of null-subject languages are given in (24).22

(24) a. Only null pronominals are stylistically unmarked.

b. Only null pronouns can function as bound variables.

c. Only null 3 rd plural pronominal subjects can have arbitrary reference.

(24a) expresses the well-known fact that non-emphatic pronominal subjects are regularly omitted in canonical null-subject languages, while overt pronominal subjects are emphatic. Criterion (24b) has been adopted from Montalbelli (1984), whose analysis of pronominal binding in null-subject languages revealed that empty pronouns do not behave in the same manner as their overt counterparts. In particular, he discovered that there is a curious asymmetry between the interpretation of overt and empty pronouns. Montalbelli (1984) claims that in the following type of construction in a null-subject language an overt pronoun in the same position as pro cannot be interpreted as bound, whereas the empty pronoun has to be interpreted as bound:

22 Technically speaking, we have to differentiate between two types of null subject languages:

a) languages which license and identify null subjects

b) language which just license null subjects

In the following I use the term (canonical) 'null-subject language' synonymously with type a), unless otherwise stated. 
(25) a. muchos estudiantes piensan que ellos son inteligentes

'many students think that they are smart'

b. muchos estudiantes piensan que pro son inteligentes

I do not completely agree with Montalbelli that the only interpretation which is possible for $(25 b)$ is a bound reading:

(26) (many $x: x$ a student) $x$ thinks $x$ is intelligent

Instead, a referential (free) interpretation of the empty pronoun is also possible, even though this is not the most likely interpretation, especially if a sentence is given to a native speaker without any context. However, what is most crucial for our discussion, the bound variable reading in (26) is not available for (25a). In English, on the other hand, the interpretation of the pronoun they is ambiguous between a bound and free interpretation. Montalbelli emphasizes that his "overt pronoun constraint" is only valid for positions where the overt/empty alternation is available. The interpretation of the overt possessive pronoun in sentence (27) is ambiguous in both Spanish and English. In Montalbelli's account this is expected, since the overt possessive pronoun does not have an empty counterpart.

(27) muchos estudiantes piensan que sus bicicletas son azules

'many students think that their bicycles are blue' 
A version of Montalbelli's overt pronoun constraint can then be defined as follows:

(28) Overt pronouns cannot be bound if the option overt/empty is available.

Criterion (24c) is derived from Jaeggli's (1986) analysis of the so-called arbitrary plural construction. Jaeggli points out that this type of construction occurs in both English and Spanish, indicating that its existence is independent of the setting of the null-subject parameter.

However, while in English it is the overt pronoun they which functions as the arbitrary plural pronoun, as illustrated in (29), in Spanish only a null pronoun can be intexpreted as arbitrary in reference. According to Jaeggli (1986) an overt pronoun in Spanish can only be interpreted as non-arbitrary. In (29) the lexical pronoun they is ambiguous between a specific referential reading (a group of more than one person) and an arbitrary reading (someone; one or more people). In Spanish, there is again a division of labor between overt and null pronouns, although perhaps less clearly so than stated by Jaeggli. Examples (30a) and (30b) below are cited from Jaeggli (1986). Some Spanish informants were less willing to interpret $(30 \mathrm{~b})$ with an arbitrary reading, but all agreed that 
(30a) certainly cannot have an arbitrary reading. The same results obtained in the constructed examples (3la) and (31b). ${ }^{23}$

(29) they don't allow alcohol on campus

(30) a. ellos llaman a la puerta 'they call $l_{\text {3p }}$ at the door'

b. pro llaman a la puerta

(31) a. aqui ellos no permiten las bebidas alcoholicas 'here they don't allow alcohol'

b. aqui pro no permiten las bebidas alcoholicas

The pronoun ellos in (30a) and (31a) must have a specific group of people as reference, while the null pronominal in $(30 \mathrm{~b})$ and $(31 \mathrm{~b})$ is ambiguous between definite reference and arbitrary reference. Jaeggli unifies this property of nullsubject languages with Montalbelli's analysis, proposing that the overt pronoun constraint and the constraint which does not allow an overt pronoun to have arbitrary interpretation in null-subject languages, are reflecting the same underlying principle. In contexts where the overt/empty alternation is available, overt pronouns must be specified as [-dependent]. that is independent in reference, while empty pronouns are [+dependent], fixing their reference by linking to an antecedent

23 Part of the problem seems to be that Spanish has another tensed construction with arbitrary null subject, the so-called impersonal se construction, which native speakers tend to prefer over the arbitrary plural construction discussed here. 
through some sort of binding mechanism. ${ }^{24}$ As for the arbitrary plural construction, a [+dependent] third-person pronominal is assigned the arb index at LF if it lacks an antecedent. Jaeggli's constraint on the arbitrary interpretation of overt pronouns is then defined as follows:

(32) Overt pronouns may not be arbitrary in reference iff the overt/empty alternation obtains. solution to which lies outside the scope of this work. Jaeggli is not very specific as to what kind of binding relation "in an extended sense of the term" is involved for (+dependent] elements to fix their reference. For instance, in Spanish any null pronominal in subject position is specified [+dependent]. Thus, in the following sentence the null pronominal has to $f i x$ its reference by linking to an antecedent. supposedly by being bound by AGR located in the finite INFL.

(i) pro compró un pulpo

'he/she bought an octopus'

AGR in this instance contains only person and number features. Therefore, when uttered outside any context the sentence is ambiguous between he and she, so that coindexation with some "outside" antecedent seems necessary to fix reference to gender. Furthermore, [-dependent] pronouns also seem to fix their reference via "some kind of binding relation" to an antecedent.

Also consider the problem which arises in the following type of constructions: (example from Montalbelli 1986: 140)

(ii) muchos carniceros creen que pro compraron un pulpo 'many butchers think that pro bought an octopus'

Here the [+dependent] pronominal subject has to act as a bound variable, being bound by 'many butchers'. However, it seems that at the same time it will be bound by the AGR of its own clause, for the same reasons as in the above example (i). A third connected question is whether or not empty lst and 2nd person subject pronouns in null subject languages should also have the specification [+dependent] or not. Note that for them, being bound by INFL does suffice to fix their reference. 
While we are not concerned about the details of Jaeggli's analysis, it is important because it constitutes the basis for the third of our null-subject diagnostics. In summary, the characteristics under (24) can be taken as fairly reliable diagnostics as to whether or not a language belongs to the canonical null-subject languages. In the next chapter these diagnostics will be applied to slavic. 
$-40-$

\section{NULL-SUBJECT CEARACTERISTICS OF SLAVIC LANGUAGES}

\subsection{Application of null-subject diagnostics}

The last section of the previous chapter presented a set of three diagnostics (repeated here as (1)) to determine the canonical null-subject status of a language.

(1) The following properties hold true for null-subject languages :

a. Oaly mull pronominal subjects are stylistically unmarked.

b. Caly mull pronouns can function as bound variable.

c. Only null 3 rd plural pronominal subjects can have arbitrary reference.

The next step is to apply these diagnostics to slavic. We shall take Russian as representative for East Slavic, SerboCroatian for South Slavic, and Czech for West Slavic.

\subsubsection{Weet slavic and south slavic}

By these criteria most West and South Slavic languages are canonical null-subject languages.' Both Czech and SerboCroatian do not normally lexicalize pronominal subjects of tensed clauses, as illustrated in (2) and (3). The use of overt pronouns is generally reserved for contrast, emphasis, or a change in discourse topic, shown in (4) and (5).

1 For Sorbian, which does not behave like a canonical null-subject language, see Chapter 5 . 
(2) Casto pro vstávám brzo

(3) Cesto pro ustajem rano

'often (I) get up early'

(4) Alena vstává brzo, a já Casto vstávám pozdé

(5) Jovan ustaje rano, a ja Casto ustajem kasno 'A/J gets up early, but I often get up late'

Diagnostics (1b) and (1c) provide further evidence that Czech and Serbo-Croatian are null-subject languages. The Czech examples under (6) and Serbo-Croatian examples under (7) pertain to (1b), demonstrating that only null pronouns can have bound variable readings.

(6) a. každý student si myslı, ze pro dostane jedniðku b. každý student si myslí, ze on dostane jedniðku

(7) a. svaki student misli da ce pro dobiti desetku b. svaki student misli da ce on dobiti desetku 'every student thinks that he will get an $A$ '

The bound variable reading rendering interpretation (8) can only obtain in examples $(6 a)$ and $(7 a) .^{2}$

(8) ((every $x$ : $x$ a student) $x$ thinks $x$ will get an $A$ )

2 The fact that the overt pronoun in the example below may be bound to the quantifier phrase rendering interpretation (ii) is not a contradiction to what has been said so far. In the position after a preposition there is no alternation between empty and overt pronouns and hence Montalbelli's overt pronoun constraint does not apply.

(i) každi student chce, aby Maria hrála s ním

(ii) ( (every $x$ : $x$ a student) $x$ want that $M$. play with $x$ ) 
Examples (6b) and (7b), which have overt pronouns, can only be understood in the sense that every student thinks that a particular person is getting an A.

Examples (9) and (10) provide an application of diagnostic (1c). In Czech and Serbo-Croatian, the arbitrary reading obtains only if the subject is $3 \mathrm{rd}$ person pro instead of overt oni.

(9) a. pro v tom obchode prodávajs kávu

b. ont $v$ tom obchode prodávaji kávu

' in this store they sell coffee'

(10) a. pro ovdje prodavaju kavu

b. onl ovdje prodavaju kavu

'they sell coffee here'

The overt pronouns in (9b) and (10b) necessarily give rise to the [-dependent] interpretation, so that oni in those sentences must refer to a specific group of people.

\subsubsection{Rusaian (Bast Slavic)}

It is easy to find Russian examples with zero subjects in tensed clauses, especially in colloquial Russian or artistic texts imitating colloquial style. The following examples were found in stories by Sokolov, Jerofeev, Romanina (Innis 1985). 
Missing subjects in the Russian text are marked with \#, other missing material is given in brackets. ${ }^{3}$

(11) On zametal, ťo \# dumaet o nej postojanno, $i$ radovalsja, tto \# nitego ne xołet ot neè, i znacit \# dejstvitel'no ljubit (eë).

'He realized that (he) was constantly thinking about her, and rejoiced that (he) didn't want anything from her, that means (he) really loved her.'

(12) No daze esli by ja pomnil sejcas eẻ imja, to \# ne stal by nazyvat' (ego), kakoe vam delo.

'But even if I remembered her name right now, then (I) would not name it, what business of yours is it.'

(13) Ja ej i stēkla skol'ko raz vstavljal, i peð' perekladyval,... a ni razu \# ne ugostila (menja). Den'gi \# daēt (mne), a nastèt ètogo nol'.

' I put windows in several times for her, and moved the stove, but (she) didn't invite me for dinner a single time. (She) gave me money, but nothing ever came of it.'

(14) Budet vremja - i krys̆u \# pocinju. A v tot den' $\mathbf{s}$ utra stëkla \# votavljaju.

' If there is time - (I) will fix the roof as well. But on that day (I) I'm putting in windows from early morning on.'

3 Non-overt subjects are very frequent when clauses are coordinated:

(i) on vošèl v komnatu, \# sel za stol i \# nacal rabotat' 'he entered the room, sat at the table and started working'

I analyze these cases as VP conjunction, and therefore not as instances of empty/missing subjects. The second and third verbs "share" the subject with the first verb. Therefore, sentence (i) should be represented by the structure (ii) and not ( $i i i)$.

(ii) [s[Npon] [vp[vp vošl $v$ komnatu] i [vp sel za stol]]

(iii) [ ls lNp on] [vp vosël v komantu]] i ls e [vp sel za 
(15) Prokuror - on pobelel ves'. \# govorju daže gazetu perestal citat'. \# Xodit po ucastku - nogami oduvanciki \# topłet.

'The state attorney turned completely pale, (I) say, and even stopped reading the newspaper. (He) walks along the plot, with his feet (he) tramples dandelions.'

(16) Vse govorjat: Kreml', Kreml'. Oto vsex ja slyłal pro nego, a sam \# ni razu ne videl (ego). Skol'ko raz uze, tysjacu raz, napivžs' ili s poxmeljugi. \# proxodil po Moskve s severa na jug, s zapada na vostok ... - i \# ni razu ne videl Kremlja.

'Everybody says: The Kremlin, the Kremlin. From everybody I hear about it, but (I) myself haven't seen it a single time. How many times already, a thousand times, drunk or with a hangover, did (I) walk through Moscow from North to south, from West to East, but not a single time did (I) see the Kremlin."

Several authors (Müller (1989); Kosta (1990); Benedicto (1994)) have argued that Russian is a canonical null-subject language. One reason for this judgement is undoubtedly the wide range of examples with missing subjects which can be cited. Below I will argue against this claim on the basis of the null-subject diagnostic tests. I essentially agree with Franks (1990), who analyzes missing subjects in examples comparable to the ones above as being deleted at PF due to some kind of discourse-licensed ellipsis. Such loss of lexical material in Russian is clearly not restricted to subjects, and thus should be treated separately from the pro-drop phenomenon. (Colloquial) Russian in general has a strong tendency toward the deletion of lexical material which is recoverable from the context, so that the "loss" of subject pronouns is 
just a part of this larger phenomenon." Examples (11-13), and (16) cited above illustrate deletion of direct and indirect objects. Ellipses of complementizers as shown in (20) and (21) (examples cited from Nakhmovsky and Leed (1988)) and verbs as shown in (17) and (18) are also frequent: 5

4

Huang (1984) proposed a "discourse-oriented vs. sentence-oriented" parameter. Nichols (1985) suggested that Russian is a very discourse-oriented language. Discourseoriented languages tend to follow a rule according to which topic NPs are deleted under identity with a topic in the preceding sentence. Example (13), repeated below, illustrates the complexity of this phenomenon:

(i) Ja ej i stêkla skol'ko raz vstavljal, i pec' perekladyval,.. a ni razu (ona) ne ugostila (menja). Den'gi (ona) daět (mne), a nastèt ètogo nol'.

'I put windows in several times for her, and moved the stove, but (she) didn't invite (me) for dinner a single time. (She) gave (me) money but nothing ever came of it.'

The speaker and a female person are the "known entities" or topics of the discourse. The omission of the first ona is particularly interesting, since this is actually a case of contrast, where we would expect overt pronouns in a pro-drop language: 'I did this, but she didn't do that...'

It is also worth mentioning that most Russian speakers, while allowing missing objects due to ellipsis, do not allow "syntactically active" pro-objects, as in Rizzi (1986):

(ii) il bel tempo invoglia a restare

'the good weather invites pro [PRO to stay]'

*xoroßaja pogoda soblaznjaet ostavat'sja

s Similar elliptical constructions with missing verbs or complementizers were rejected by Serbo-Croatian informants. Example (i) equates to (ii) in Russian as (iii) does to (20).

(i) *Knjigu \# vam? (dati)

'Should I (give) you the book'

(ii) knigu \# vam?

(iii) *Dima došla \# Jovan jos spavao. (kada)

This indicates that there is not a direct relationship between the ellipsis phenomenon and pro-drop properties of a language. 
(17) kuda ty (idës')

'where do you (go)'

(18) ty (prixodis') ko mne

'do you (come) to me'

(19) Dima prišèl (kogda) ja ešẽ ležala

'Dima came (when) I still was lying'

(20) u nas novaja sosedka (kotoruju) Natašj zovut

'we have a new neighbor (whom) they call Natasha'

Here I will not be concerned about exactly which factors allow recoverable lexical material to be deleted at $\mathrm{PF}$, nor will I attempt to determine if a "bound variable and zero topicn analysis à la Huang (1984), as discussed in the previous chapter, would also apply to Russian.' The real problem for this work is that (what are in my view) discourse licensed null subjects may appear to exhibit the null-subject properties in (1), giving the (false) impression that Russian is a canonical null-subject language. ${ }^{7}$

6 At first glance it might be tempting to attribute ellipsis of subjects to "rich" INFL. However, this "explanation" fails to account for the deletion of objects, verbs and conjunctions, and once we claim that zero subjects in Russian are part of a larger phenomenon we would also like to give a unified account of the recoverability conditions of deleted constituents.

7 One might actually want to argue that missing subjects in Russian are not stylistically unmarked, hence failing criterion (1a). Instead, they may be marked, perhaps as "intentionally colloquial". Jakobson (1939:150) wrote in that context: "... en russe c'est justement l'omission excessive du pronom de la première personne que Dostojevski éprouve comme une morgue irritante" 1 ' ... in Russian it is precisely the excessive omission of the pronoun of the first person which Dostoyevsky felt to be an annoying arrogance'). 
Since the diagnostic tests boil down to a division of labor between overt and null subjects in null-subject languages. one can couch the same conditions in terms of overt subjects."

(1') a. Overt subjects are stylistically marked.

b. Overt subjects cannot function as bound variables. c. Overt subjects cannot be arbitrary in reference.

The important point is that overt subjects in Russian also exhibit the properties under (1) and not those under (I'). This means that Russian does not exhibit the division of labor between null and overt subjects which one would expect for a true null-subject language. In order to avoid misjudgments based on the occurrence of null subjects in languages like Russian, the following investigation will focus on the interpretive possibilities associated with overt subjects as summarized above in (1').

First, in contrast to most West and South Slavic languages as exemplified by Czech and Serbo-Croatian, there is nothing emphatic about the overt expression of a pronominal subject in Russian.
(21) a. ja ponimaju vas
[Ru]
b. ja vas rozumím
[Cz]
c. ja vas razumem
[SC]
'I understand you' 
In Czech and Serbo-Croatian, the presence of an overt subject clearly indicates opposition, contrast or emphasis, while this is not the case for Russian. In neutral literary style, the use of overt pronouns in Russian is often obligatory, and the dropping of a subject is felt as incomplete and elliptical by native speakers. The normal way of saying 'I love Peter' in Russian is ja ljublju Petra with the subject ja, while in Czech the normal way is miluje Petra without a subject. Russian speakers learning Czech or Serbo-Croatian find the regular lack of pronominal subjects very striking and must make a conscious effort to avoid the overuse of overt pronouns. That should not be the case if Russian were a canonical null-subject language. Sentences (22-24) provide more examples of this contrast between Czech and Russian:

(22) a. mluvil jste $s$ jeho Zenou

b. vy govorili s ego zenoj

[RU]

'you talked to his wife'

(23) a. došla pro mléko

b. ona sxodila za molokom

' she went for milk'

(24) a. bydlim v Americe

b. Ja Zivu v Amerike

[RU]

'I live in America'

Criterion (1b') similarly divides the slavic languages into East, on the one hand, and West and South on the other. Russian in (25) allows the bound variable reading despite the 
presence of the overt pronominal subject, but this option does not exist for the otherwise identical Czech $(6 \mathrm{~b})$ and SerboCroatian (7b) examples repeated below as (26) and (27).

(25) každy student dumaet, Cto on poluxit pjatërku [Ru] 'every student thinks that he will get an A'

(26) každý student si mysli, že on dostane jedniðku

(27) svaki student misli da ce on dobiti desetku

In Serbo-Croatian and Czech the overt pronoun cannot be bound by the quantified expression, while in Russian (and English, for that matter), the overt pronoun can render the bound variable interpretation in (8) repeated here as $(28)$.

(28) ((every $x$ : $x$ a student) $x$ thinks $x$ will get an A)

Roughly the same results obtain if the $Q P$ is replaced by a referential NP, as in $(29-31)$.

(29) Ivan dumaet, ť to on $n_{i j}$ politit pjatërku [Ru] 'Ivan thinks that he will get an A'

(30) $\mathrm{Jan}_{\mathrm{i}}$ si myslY, ze on.vj dostane jedničku

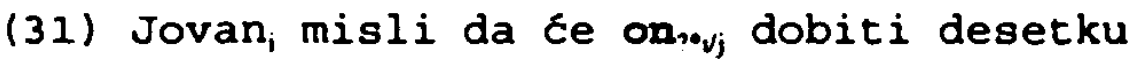

Using the overt pronoun instead of pro in a null-subject language therefore leads to a deictic, i.e. non-dependent interpretation, so that the intentional coreference of an overt pronoun in a subordinate clause with the matrix subject is 
impossible, or at best extremely marginal, in null-subject languages.

According to the third criterion, an overt subject pronoun in a null-subject language cannot be arbitrary in reference. It turns out that this test, although less obvious, further supports the proposed division of Slavic languages." The Russian arbitrary 3rd plural construction is normally described as requiring that the subject be phonologically null. However, some Russian native speakers nevertheless confirmed that the examples in (32) can have an arbitrary interpretation. 10

(32) a. v Amerike oni govorjat po-anglijski

' in America they speak English'

b. vo Francii oni edjat ulitok

'in France they eat snails'

c. na benzokolonkax oni prodajut sigarety

'at gas stations they sell cigarettes'

Although the constructions may not be normative with respect to literary Russian, the point is that the presence of an overt pronoun does not actually force a non-arbitrary interpretation. In Serbo-Croatian and Czech, on the other hand,

9 In general, this test seems less reliable than the other two null-subject criteria. Native speaker judgements about the possibility or lack of an arbitrary interpretation of an overt pronoun vary, not only in Russian but also in Sorbian, as illustrated in Chapter 4.

10 See Lindseth and Franks 1994; Sperling 1990. 
the presence of an overt pronoun does not allow an arbitrary interpretation, as discussed above.

I therefore conclude that Russian (East slavic) is not a canonical null-subject language, while Czech (West Slavic) and Serbo-Croatian (South Slavic) are. The observation that Russian is different from other slavic languages with respect to the expression of subject pronominal is not a new one. Jakobson, for instance, wrote (1939: 150):

Le russe présente deux variantes stylistiques pour dire "je vais /en voiture/": ja jedu /avec pronom personnel/ et jedu /sans pronom/. De même, en tchèque: já jedu et jedu. Cependant, il y a là une grande différence entre les deux langues: ...... en russe, c'est la construction à deux termes qui est le type "normal", tandis que la variante à sujetzéro est un procédé expressif. En tchèque, au contraire, le zéro d'expressivité se rapporte au sujetzéro, et la valeur expressive s'attache au type já jedu."

Interestingly, even some authors who claim that Russian is a pro-drop language comparable to Czech do point out that there is a difference between the languages concerning the properties of zero and overt pronouns, respectively. Koktová (1992: 40.41,60), for instance, investigating the variation among "anaphoric expressions" in Czech and Russian sentences

11 'Russian has two stylistic variants to say I'm going / by car /": ja jedu /with a personal pronoun/ and jedu /without pronoun/. The same, in Czech: já jedu and jedu. However, there is a big difference between the two languages: ... in Russian it is the two-termed construction which is the "normal" type, while the variant with the zero-subject is an expressive mode. In Czech, on the other hand, zero expressiveness is related to the zero-subject, and the expressive value is attached to the type ja jedu.' 
of the type Karel, Yekl, Ze $0_{i}$ płijde ('Karek said that (he) would come') / Misa skazal, tto $\left\{0_{i} / O n_{i}\right\}$ priedet ('Misa said that (he)/he would come') writes: ${ }^{12}$

My major claim is that in Czech, the basic variation is between the zero form and the anaphoric NP as unmarked anaphoric expressions (the personal pronoun on being highly marked, occurring only in emphatic (emotional contexts) ... On the other hand, in Russian, the basic variation is between the zero form or the personal pronoun on ... Unlike Czech, the relation of the primary (zero) and secondary anaphoric expressions in Russian is rather loose; these two anaphoric expressions (the zero form and the pronoun on) are almost freely interchangeable.

12 "Anaphoric" in this context refers to a pronoun or full NP which derives its reference by virtue of being linked to an NP in a preceding clause. The use of an overt ("secondary") anaphoric expression in a pro-drop language means that a certain amount of explicitness is necessary to avoid ambiguity. According to Koktova, the major condition for the usage of an anaphoric NP (instead of the primary anaphoric expression which is zerol in Czech is a nonsubject antecedent, especially if there is a danger of ambiguity (sentence (i) is a slightly changed version of Koktova's example).

(i) Pavel, Alene, nic nedal, protože Alena, zlobí 'P. didn't give A. anything, because A. is bad'

The use of an overt pronoun ona would presumably be highly marked and only possible in emphatic (emotionaliy colored) context. Thus, the Czech and Russian examples below are not equivalent. Instead, (iii) corresponds to example (i) above.

(ii) pavel Alenè nic nedal, protože ona zlobs

(iii) Pavel Alene nicego ne dal, potomu tto ons ploxo sebja vedët [RU] 


\subsection{Why is Russian different?}

\subsubsection{The intuitive explanation}

The conclusion that Russian (East Slavic) does not qualify as a canonical null-subject language, while Czech (West Slavic) and Serbo-Croatian (South Slavic) do. leads inevitably to the question of why East Slavic is different from the other languages. First of all, the question arises whether or not Russian does not license any null subjects. Within Jaeggli and Safir's framework, this would be unexpected. The Russian verbal paradigm has only derived inflectional forms and thus seems to meet the morphological uniformity hypothesis. Therefore null subjects should be licensed in Russian. Indeed. expletives in Russian may (and generally must) remain phonologically empty. ${ }^{13}$ None of the verbs in $(33-36)$ assigns a theta-role to its subject. The first two are weather-verbs, (35) contains a so-called raising verb and (36) a passive.

(33) pro temneet getting-dark

'it's getting dark'

(34) zdes' pro duet

here blows

'there is a draft here'

13

Some dialects allow overt expletives, as can be seen in the following example taken from woolhiser (1994):

ono tëplo $v$ izbe

it warm in cabin

'it's warm in the cabin'

Overt expletives in Slavic languages are discussed in $\mathrm{Ch} .5$. 
(35) mne pro kažetsja, tto on ne ponimaet menja me seems that he not understand me

'it seems to me, that he doesn't understand me'

(36) pro bylo napisano ob ètom $v$ gazete was written on this in paper

'They wrote about this in the newspaper'

The problem which arises is how we can determine what it is which blocks the identification of referential null subjects in Russian. Before trying to formalize this though, it is worth looking at the "old" intuition that there is a correlation between the richness of verbal agreement morphology and availability of null subjects in a language. We should be able to find a relevant difference in the overt expression of agreement features between Russian and the languages which represent west and South Slavic in this discussion.

The present tense paradigm of Russian actually has distinct endings for every person/number combination, as does Serbo-Croatian which is a canonical null-subject language. Czech even has a syncretism between the 3 rd person singular and plural within one conjugational pattern. ${ }^{14}$ The conjugational paradigms for verbs with infinitival $a$ - and $i$ - stems given in Tables 1 and 2 below illustrate this.

14 For a discussion on the allowable numbers and types of syncretisms see section 4.5.1. 
Table 1: Conjugational Paradigms: a-stems

RU: obedat'

lsg obedaju

2 sg obedaes.

3 sg obedaet

ipl obedaem

2pl obedaete

3 pl obedajut
CZ: obedvat obẽdvám obedvás obèdvá obedváme obedvate obedvaj 5
SC: ručati

Table 2: Conjugational Paradigms: i-stems

RO: govorit'

Isg govorju

$2 \mathrm{sg}$ govoris'

$3 \mathrm{sg}$ govorit

ipl govorim

2 pl govorite

$3 \mathrm{pl}$ govorjat
CZ: hovorit

hovołim

hovolis

hovori

hovorime

hovolite

hovors
SC: govoriti

Therefore, the present tense paradigm of Russian does not give us the desired answer. At first glance, Russian appears even more qualified to license null subjects than Serbo-Croatian. Within the Jaeggli and Safir system, forms with zero endings, such as the 3 rd person singular of the Serbo-Croatian verbs above, pose a potential problem. Recall that licensing in this framework is the result of consistency in the entire paradigm: Null subjects are licensed in languages with either only derived or only non-derived verb forms. If a zero within a paradigm of otherwise consistently derived verb forms is truly an affix itself, then the paradigm can still be uniform. However, if the zero represents no ending at all, then the paradigm is derivationally mixed, and null subjects should not be licensed. The question is whether or not the potentially 
problematic 3 rd person singular forms ruta and govori in the Serbo-Croatian paradigms are bare stems. It turns out that we can claim in keeping with Jakobson's (1948) "one stem system" that these forms do actually involve morphologically active, or "real" affixes. First, there is evidence that the serboCroatian form ruta involves a consonantal zero ending. Assuming that the basic stem is "ruxaj-", we can account for the 3rd person singular present tense form by arguing that the consonantal zero affix of the 3 rd person causes truncation of the jot due to the unstable $C+C$ environment, just as the $m$ of the lst person singular or $t$ of the infinitive causes truncation of the jot:

$$
\begin{aligned}
& \text { (37) rucaj + ti } \rightarrow \text { rucati (infinitive) } \\
& \text { rucaj }+m \rightarrow \text { rucam (1st sg) } \\
& \text { ruxaj }+\theta_{1+\text { mas }} \rightarrow \text { ruta } \quad \text { (3rd sg) }
\end{aligned}
$$

The jot of the basic stem is evident in the imperative form rucaj. It is possible that such imperative forms really have no endings at all. However, that would be no problem for the morphological uniformity criterion, since the imperative in general seems to behave independently from the null-subject parameter. Note that even in canonical overt-subject languages 
such as English, there is no overt expression of the subject of an imperative. is

Within the same system, the forms govori and govoris in Serbo-Croatian actually derive in the following way:

$\begin{aligned} \text { (38) govori }+i & \rightarrow \text { govori (3rd sg) } \\ \text { govori }+i s & \rightarrow \text { govoris (2nd sg) }\end{aligned}$

Supporting evidence for this analysis, in opposition to assuming "govori $+\theta_{1+\operatorname{coss}]}$ " and "govori $+\xi "$, comes from verbs like

Is Feldstein (1987) comes to a comparable conclusion in his analysis of Polish czyta (read $3 \mathrm{sg}$ ), while he posits a "real" zero desinence for the imperative czytaj (imperative, 2sg.). Working with Jakobson's (1948) one-stem system, he posits "czytaj" as the basic stem. It has been considered a problem for the one-stem system to explain why a zero-ending causes the jot to truncate in one form ( $3 \mathrm{rd} \mathrm{sg}$ ) and not the other (imperative). Feldstein proposes that Polish verbal desinences in the non-past, including zero endings. can be further segmented into smaller units representing the conjugation class, person and number. Based on phonological evidence (i.e. the occurrence of interword sandhi) he assumes that there is a word boundary between the zero unit and the person and number endings in the imperative. He further proposes special truncation rules to deal with desinences which contain zero elements. If a zero is accompanied by a non-zero unit within the same word boundary, then the zero remains without any effect on truncation. If there is only a single zero within the word-unit, the zero desinence behaves like a vowel. This is the case in the imperative, and consequently the jot is not truncated. If there are multiple zeroes present within the word unit, they have the truncation effect of a consonant. This is the case in forms like czyta. The behavior of the different "zeroes" is illustrated below (\# signifies a word boundary).

$$
\begin{array}{ll}
\text { czytaj }+\varnothing+\varnothing+\varnothing \# \text { : czyta }(C+C \text {; truncation of "jot") } \\
\text { czytaj }+\varnothing \# \varnothing+\varnothing \# \text { : czytaj ( }+V \text {; no truncation) }
\end{array}
$$

It is obvious how this analysis could be extended to serboCroatian as well. 
Zeleti which obviously belong to the same conjugation class as govoriti :

(39) Zelim Želiš そeli želimo želite そ̌ele

The personal endings of this conjugation type are thus $\{-i m$, -is. $-i ; i m o, i t e, e\}$, and the basic stems for the two verbs above are "govori" and "Žle" respectively. Following Jakobson's rules for combining basic stems with endings, the final vowel of the basic stem is truncated due to the unstable $V+V$ environment when the vocalic personal endings are added. The infinitive ending $(-t i)$, on the other hand, is consonantal, and no truncation occurs when it is added to the vocalic basic stem.

I assume that the Czech form dela (3rd singular) also involves a zero consonantal affix. All the forms of the paradigm above can be derived from the basic otem "delaj", provided that there is a special rule of vowel lengthening in Czech in $C+C$ environments in the non-past paradigm. This is illustrated in $(40)$.

$$
\begin{aligned}
& \text { (40) dělaj + m } \rightarrow \text { délám (truncation; lengthening) } \\
& \text { délaj }+\theta_{1+c o m s} \rightarrow \text { déla (truncation; lengthening) } \\
& \text { dělaj + I } \rightarrow \text { dělaj }
\end{aligned}
$$

We have seen that there is nothing in the present tense paradigm of Russian which would account for the lack of identification of null subjects. However, there is a crucial 
difference in the past tense formation between East slavic on the one hand and West and South on the other, which will be discussed below.

Historically, Old Church Slavonic (OCS) was pro-drop, while modern Russian is not. The question is, then, what happened over time which could have caused the loss of prodrop in Russian. The answer lies in the development of the past tense(s). OCS had four different past tenses: The aorist and the imperfect, which were simple tenses, and the perfect and the past perfect, which were compound tenses. Many Slavic languages today, including Russian, have only one past tense, which is derived from the perfect tense of ocs. ${ }^{16}$ The perfect tense in slavic was originally formed analytically with a present tense form of byti ('to be'), indicating the grammatical categories of person and number, and the short form of the 1-participle which showed agreement in gender and number with the subject, as shown in Table $3 .{ }^{17}$

16

The decline of the aorist and imperfect took place relatively early in Russian. It is difficult to give an exact time frame, since this process is reflected differently in different manuscripts. Also, the bookish church style seems to have been much more conservative than the secular (delovoj) style, where these tenses become less frequent at an earlier point in time. Ivanov (1990) gives the $13 \mathrm{th} / 14 \mathrm{th}$ centuries as an approximate time for the considerable decline of the imperfect and the aorist in Russian.

17 The dual number is not crucial for the discussion and is not listed in Table 3 . 
Table 3: ocs Perfect Tense

\begin{tabular}{cllll} 
sg. & & masc. & fem. & neuter \\
\hline Int & jesmb & xodilb & xodila & xodilo \\
2nd & jesi & xodilz & xodila & xodilo \\
3rd & jestb & xodili & xodila & xodili
\end{tabular}

P1.

$\begin{array}{lllll}\text { 1et } & \text { jesmb } & \text { xodili } & \text { xodily } & \text { xodila } \\ \text { 2nd } & \text { jeste } & \text { xodili } & \text { xodily } & \text { xodila } \\ \text { 3rd } & \text { sotb } & \text { xodili } & \text { xodily } & \text { xodila }\end{array}$

Russian lost the original gender distinctions in the plural and the nasal vowels (stọtb $\rightarrow$ soutb) relatively early ( 12 th/13th centuries). Otherwise, the system above can be found in early old Russian texts.

Sentences (41) and (42) are examples of an intact, perfect tense in Russian Church Slavonic manuscripts: ${ }^{18}$

(41) a. ne dalb jeei kozblete (Ostromir's Gospel 1056-7) not gave aux gat $_{\text {sot }}$

' (you) have not given a goat'

b. věmb jako otz boga jesi prǐelb (ibid)

know that from God aux 2 arrived

' (I) know that (you) have come from God'

(42) jako ze oci soutb ustavili i zapovzdali as emph. Fathers aux $x_{3 p 1}$ established and commanded tako ze stvori same. (Izbornik Svjatoslava 1076) so emph. do mperwe self

'as the fathers have established and commanded so do yourself'

18 Examples are cited from Ivanov (1990: 332-337) and Avanesov and Ivanov (1982: 92-106). 
However, the manuscripts of the 11 th and 12 th centuries already exhibit a frequent use of the perfect without auxiliary, of which (43) is the oldest attested example:

(43) glebb knjazb mbrilb more (Tmutorokan Stone; 1068) 'prince Gleb measured the sea' (missing aux ${ }_{3 s g}$ jestr)

(44) ježe otbcb dajalı i rodi słdajalı (B-bark \#9; 1100s) ' what father bequeathed and relatives bequeathed' (missing aux 3rg $_{\text {jestz }}$ aux $_{3 \mathrm{pl}}$ sotz)

The following examples taken from 13 th and 14 th century manuscripts show the continuing loss of the auxiliary in the perfect tense.

(45) a. otbcb moi oumerlb (Laurentian chronicle; 1377) father my died 'my father died'

b. gde ze ne xodill ni dedi naši (ibid) where emph. not went nor granddads our

'where our grandfathers didn't go'

c. vb se ze leto $v$. ratb pocalb (ibid)

in this emph. year $V$. war started

' in this year $V$. started the war'

(46) ne reklb mi jesifb (B-bark \#3; 14th cent.)

not said me Joseph

'Joseph didn't tell me'

(47) Sto selb pokupili bojare (Novgorod chart. 1368-71) that land bought Boyars

'and that Boyars bought the land'

(48) bratb drjals nasilie (Novgorod charter 1264-65) brother did violence

'the brother committed violence' 
Several scholars, including Ivanov (1990) and Cernyx (1954), point out that this loss of the auxiliary was particularly frequent in the 3 rd person with overt subjects. This is reflected in examples (48-51) above, which all have full NPs as subjects. According to Cernyx, the Smolensk Charter from 1229 uses the perfect tense of the 3 rd person 23 times, but not a single time with the copula. There is a good reason why the loss of the auxiliary seems to prefer the 3 rd person. The examples from the manuscripts show that the copula was dropped when the loss of the pronominal features was compensable by the occurrence of an overt subject. If we assume that old Russian was still pro-drop at that stage, then overt subjects (pronouns) of the 1st and 2nd person were only used in emphatic contexts. For the 3 rd person, on the other hand, any full NP could act as the non-emphatic subject and thus the instances of sentences with overt subjects in the 3 rd person were much more frequent. Although the auxiliary was preserved longer in sentences with 1st and 2nd person subjects, there are also early examples for the loss of the copula in these persons, as illustrated below.

(49) ja dalb rukoju svojeju (Mstislav's charter 1130)

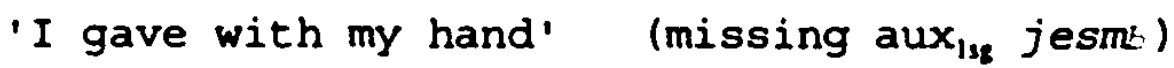

(50) ty osklabilb se (Antiouchus Pandects 11th century) 'you smiled' (missing aux 2 jesi)

(51) my vašee bratije ne obiděli ni grabili

(Bishop Jakov's letter to Riga, 1300)

'we didn't offend or rob our brothers' (missing $\operatorname{aux}_{\text {ipt jesms: }}$ 
The original meaning of the perfect tense was that of an event which started in the past and which continues into the present. Formally this "bridging of time" was conveyed by the present tense of the auxiliary. According to Avanesov and Ivanov (1982: 92-107), the documents of the 12-14th centuries reveal that this original meaning of the perfect tense was in transition at that time. In this context they cite several examples of formally intact perfect tenses with simple past tense meaning. The gradual loss of the auxiliary as described above may have been both a contributing factor to and a logical consequence of this process. The other purpose of the auxiliary, namely that of expressing the category of person, is perhaps more important for our investigation. As mentioned earlier, this role of the auxiliary was compensated for by the use of an overt subject, NP or pronoun. ${ }^{19}$ As the perfect tense became established without the auxiliary, overt pronouns became disassociated from their emphatic function and started to spread widely in old Russian texts. ${ }^{20}$ Ivanov points out

19 Old Church Slavonic did not have a 3 rd person personal pronoun. 3rd-person reference was made by the demonstratives $t b, s b$ and onb. The latter developed into the 3 rd person pronoun.

20 The shift in the meaning of the perfect tense cannot be interpreted as the sole reason why East slavic developed non-emphatic personal pronouns and thus lost its pro-drop properties, since the same change happened in other slavic languages which remained null-subject. It seems that all Slavic languages which use the l-participle as the simple past tense form of the verb could have gone one way (keep the auxiliary) or the other (use non-emphatic subjects pronouns), once the "bridging function" of the auxiliary was lost. In Polish, the auxiliary forms of the ocs perfect tense have 
that the formally intact perfect is still occasionally found in later manuscripts (14th and 15th centuries), especially in the religious style. Interestingly, we can find such examples of the analytical perfect tense both with and without overt subject, which shows that the use of (non-emphatic) overt pronouns (probably due to the loss of the auxiliary in normal speech) had already gained in popularity.

(52) sego ty ze esi xotðlb (Laurentian Chronicle 1377) this you emph. aux $2 s$ wanted

'you wanted this'

In summation, it seems plausible to attribute the loss of (referential) pro-drop to the reinterpretation of the 1-participle as a verbal form, which due to its participial origin, is somewhat peculiar in shape: Contrary to other forms of the verbal paradigm, it does not show person, but it does show gender instead. ${ }^{21}$

been incorporated into the verb form, functioning as desinences which represent the category of person/number. very much like desinences on present tense verb forms.

$\begin{array}{ll}\text { pytac ('to ask') } & \\ \text { present } & \text { past } \\ \text { lsg pytam } & \text { pytalem } \\ 2 s g \text { pytasz } & \text { pytales }\end{array}$

21 The fate of the past perfect, the third "extinct" tense, was indirectly influenced by the development of the other past tenses. Originally, the past perfect was formed by the imperfect of the verb byti and the 1-participle (e.g. nesli beste 'you-all had carried'). In the i3th century the past perfect started using the perfect tense of byti instead of the imperfect (e.g. nesli jeste byli 'you-all had carried'), as shown in (i). This is presumably connected to the loss of the imperfect tense at around the same time. 
In contrast to East Slavic, West and South Slavic did not drop the auxiliary verb in the formation of the past tense, so that the auxiliary has preserved its purpose of expressing the category of person/number and the personal pronouns their emphatic function, as was true for OCS. This is shown below for Czech and Serbo-Croatian.

(53) Cetla feem tu knihu read $_{\text {em }}$ aux $_{\text {ise }}$ this book

'I read this book'

(54) Citala sam tu knjigu

[SC]

\subsubsection{How to formalize the dffference between Rusein and West and South slavic}

It would seem plausible that the special development of the past tense would have necessitated the use of overt pronouns in that tense only in Russian. However, thematic null subjects

(i) a tto selb i svobodb ...

'and as far as their land and freedom ...'

to dali feame byli andreju

that gave Iman $_{\text {aux }}$ aux $_{I_{\text {pan }}}$ Andrej

'we had given it to Andrej' (Novg. charter 1304/05)

At about the same time, the perfect starts to lose its auxiliary, which is also reflected in the past perfect. This is illustrated in (ii).

(ii) a ot nemecb byli na sude iskali kolokola and from Germans aux l-pm at court searched l-pen $_{\text {bell }}$

(1284; Gramota knjazja Fedora Rostislaviða)

'but they had demanded the bell from the Germans in court'

The past perfect in this latter form is preserved until the 17 th century, but is missing from contemporary literary Russian. 
in general stopped being identified, even in the present tense where unambiguous identification never seems to have been at risk. 22 This may imply that the whole paradigm, and not parts of the paradigm or even individual verb forms, determines whether empty subjects are possible or not. ${ }^{23}$ The 3 rd person deserves further comment. In slovene, Serbo-Croatian, and both Sorbian languages the copula is used in all forms of the compound past (perfect) while the other South and West Slavic languages have a zero copula in the 3 rd person. This is illustrated below.

\begin{tabular}{|c|c|c|}
\hline (55) & $\begin{array}{l}\text { ljudje so videli } \\
\text { people aux } \text { saw }\end{array}$ & [SLN] \\
\hline & $\begin{array}{ll}\text { Janez fe } & \text { videl } \\
\text { Janez aux } & \text { saw }_{\max }\end{array}$ & \\
\hline (56) & $\begin{array}{l}\text { ljudi u videli } \\
\text { people aux } \text { spl } \text { saw }_{p}\end{array}$ & [SC] \\
\hline
\end{tabular}

22 Recall that following Jaeggli and Safir (1989) we differentiate between "licensing" and "identification" of null subjects. All null subjects have to be licensed, but only thematic subjects have to be identified.

23 A hypothesis stating that this would be universally true is inconsistent with the pro-drop properties of Hebrew (among others). In Hebrew, null referential subjects occur only in the past and future tenses, presumably because the present tense AGR is not sufficiently rich to identify pro. The situation is further complicated by the fact that $3 \mathrm{rd}$ person referential pro is licensed only in embedded contexts with an antecedent for the pro-element in the matrix clause. Pro in matrix clauses is possible only in the 1st and 2nd persons. For a possible analysis see Borer (1989). 


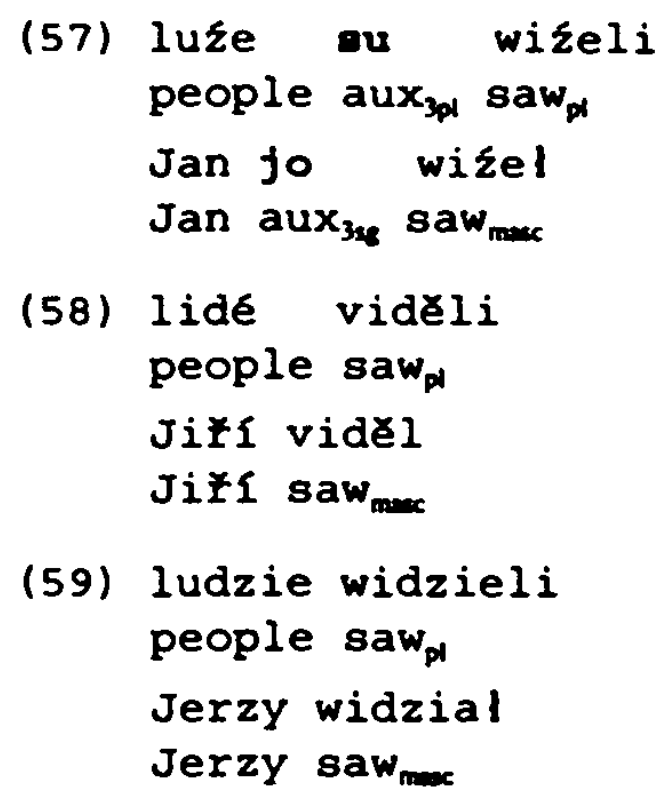

The verbal agreement feature of person is nevertheless also available in all South and West Slavic languages in the 3rd person: A zero copula signals 3 rd person. This shows that richness is not necessarily identical to overt expression of agreement features on a given verb form. In other words, it is not the lexicalization of $A G R$ on an individual verb form which makes an empty subject possible.

It turns out that to formalize what exactly blocks identification in Russian is a fairly difficult task. Since Russian actually licenses expletive subjects, an analysis à la Speas (1994) is bound to fail. Recall the split INFL hypothesis, according to which IP is decomposed into two functional projections: AGRP and TP. Speas further argues that, according to the principle of economy, a projection XP can be projected only if it has content. Since AGR has no semantic content, AGRP can be projected under two conditions: The head itself is 
filled by an agreement affix, or the specifier position is filled. ${ }^{24}$ Returning to the Russian problem, we could assume. adjusting the definition of "strong" agreement appropriately. that Russian is a language with "weak" agreement, due to the lack of agreement morphology in the past tense. ${ }^{25}$ The verbal affixes would then not have independent lexical entries, but instead be listed in the lexicon in the verbal paradigms. In keeping with the principle of economy, the specifier of AGRP would thus have to be filled, disallowing pro. However, given this hypothesis, we could not account for the occurrence of null expletives, unless we were to assume that this phenomenon

24 The 3 rd person forms without copula in West Slavic might be problematic for Speas's analysis. According to Speas (1994: 8) the relevant notion of content is the following:

A node $X$ has content if and only if $X$ dominates a distinct phomological matrix or a distinct semantic matrix.

Forms like Czech tetl ('he read') or Polish czytal do not have an overt person/number agreement affix (I assume that - $l$ is the head of TP). Consequently, following the economy of projection principle, we would be forced to assume that AGRP is not projected at all when these forms are being used, since the AGR does not dominate a phonological matrix and there is no subject occupying the specifier position. However, this theory contradicts the intuition that the agreement features are really present and available, though not phonologically present.

25 Under Speas's criteria (using Rohrbacher's (1995) "conditions for lexically listed affixes", cf. Chapter 2) Russian could also be analyzed as a "strong" AGR language. thus theoretically allowing null subjects. However, Speas also mentions explicitly that a "strong" AGR language may choose to list agreement affixes as part of the verbal paradigms, thus forcing pronominal subjects to be overt. While this also raises the question of how to account for null expletives, the main problem with Speas's analysis, from my perspective, is that it is not specific enough to say anything interesting about why Russian is different (See Chapter 4. fn. 35 for a discussion of Sorbian within Speas's system). 
in general were due to some factors unrelated to the issue of pro-drop.

In Franks (1990), Lindseth and Franks (1994), and Franks (1994) an analysis within the licensing and identification approach is proposed. Russian fulfills the morphological uniformity criterion and therefore licenses null subjects. The lack of identification in Russian can be formulated in terms of an anomaly in the functional projections of $\mathrm{V}$. The analysis corresponds to the intuition that the acceptability of pro should indeed be formulated in terms of richness of inflection. We have seen that although Slavic verbs may exhibit both person-number agreement $\left(A G R_{p o r s}\right)$ and gender-number agreement $\left(A G R_{\text {nd }}\right)$, this is realized differently in East slavic, compared to West and. South Slavic. Whereas $A G R_{\text {pers }}$ is consistently marked in South and West Slavic, in East Slavic it is absent in certain forms. Specifically, there is no present tense copula, and hence, as we have seen above, all verbs in the past tense lack $\mathrm{AGR}_{\mathrm{pers}}$ agreement morphology. In East Slavic, the two agreement types are mutually exclusive, which, in principle, would allow us to associate either type with what is generally known as the $A G R$ (or $A G R_{s}$ ) projection in the literature. However, $A G R_{p e n}$ and $A G R_{\text {gen }}$ in West and South Slavic can be present at the same time (such as in the past tense) and occupy distinct positions. The former is a relatively 
free clitic, while the latter appears unequivocally as an ending after the tense suffix -1.26

This constitutes evidence that in a full-blown functional projection system the two agreement types should be two distinct heads. The slavic clause structure could then be illustrated by the following tree structure in $(60)$, whereby the relative order of the different functional projections may vary from language to language.

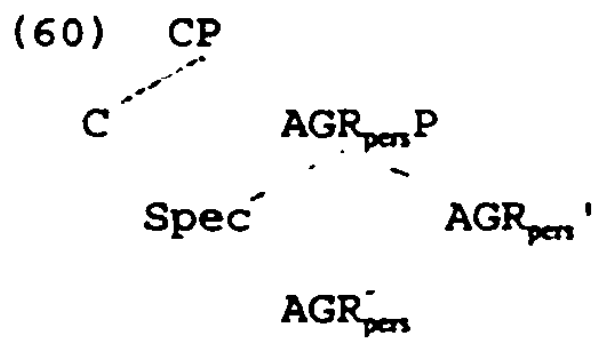

Spec

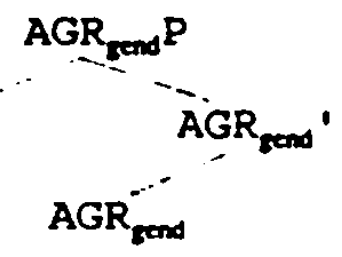

Spec

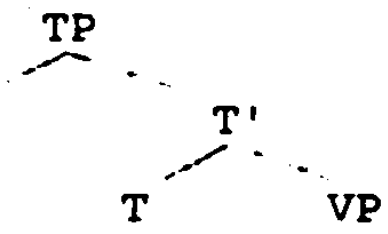

Only $\mathrm{AGR}_{\mathrm{pers}} \mathrm{P}$ seems to be relevant for the identification of referential null subjects. In west and South Slavic languages null subjects are identified despite the lack of $A_{\text {GRend }}$ in all forms of the present tense. Thus, a correlation between the availability of a null referential pro subject and the presence of $A G R_{\text {pers }}$ is proposed. Under this analysis $A G R_{p e n} P$ is

26 Even in Polish, the personal endings of the Past tense can be transferred and attached to other words in the sentence:

Gdzie bylase or Gdies byla? ('where were you') 
associated with what is usually called AGR $P$. The Russian present tense forms show full person agreement, and yet pro is no more appropriate in present tense sentences than it is in the past tense, which lacks $A_{G R}$ pers. It seems to be the absence of $A G R_{p e r s}$ in the past tense which is responsible for blocking the identification of referential null subjects in general in Russian. It should be stressed once more, as already indicated above, that what is important under this analysis is the role of $A G R_{\text {pars }}$ in the inflectional system, rather than its presence in individual forms.

\subsection{Summary}

In this chapter I applied three null-subject diagnostics to the slavic languages. By these criteria, Czech and SerboCroatian, as representatives of west and South Slavic, are canonical null-subject languages, while Russian is not. The reason why Slavic languages divide along this line is found in the different development of the past tense. Specifically, East Slavic lost the present tense copula, which led to a loss of person agreement in the past tense. The loss of the auxiliary started in sentences with overt subjects (full NPs or emphatic 1st and 2nd person pronouns), but eventually spread much further and was compensated for by the use of overt pronouns in general, which thereby lost their emphatic character. As a result, the division of labor between overt and zero pronouns, which is characteristic for null-subject languages, 
was lost. This insight was formalized by proposing two different functional projections $A G R_{\text {pers }} P$ and $A G R_{\text {reno }} P$ for the different types of agreement in Slavic. Only the former is true subject agreement in the traditional sense ( $\left.A G R_{s}\right)$ and relevant for identification of null subjects. The inconsistent realization of $\mathrm{AGR}_{\text {per }}$ was found to be the culprit for the blocking of identification in Russian. 


\section{IS SORBIAN A PrO-DROP LANGUAGB?}

The null-subject diagnostics previously applied to other Slavic languages produce the unexpected result that sorbian is not a canonical null-subject language. Three possible explanations for this are explored in section 4.6. While all three are workable in principle, the last of these, based on a competition model of language change (Sprouse \& Vance 1995), proved to present the fewest problems and give the most plausible account for the whole range of Sorbian data. This is partially due to the fact that it incorporates the broad historical context of the language.

\subsection{The Sorbian population of Germany}

Soon after the reunification of Germany, in 1991, a political scientist from Bonn wrote:

Sorben sprechen fließend deutsch, sie besitzen deutsches Wahlrecht und deutsche Pässe, sie sind deutsche staatsbürger -- aber sie sind keine Deutschen! Deutsche Kaiser, Führer und Generalsekretāre haben versucht, ihnen die Luft abzudrücken -- mal im Würgegriff, mal in der Umarmung. (Oschlies, 1991: 2)'

In general terms this 1991 commentary contains some basic points which characterize any study of the Sorbian population

1 'Sorbs speak German fluently, have German voting rights. German passports, are German citizens - - but they are not Germans. German emperors, "Führer" and General Secretaries have tried to suffocate them -- sometimes in a stranglehold, sometimes in an embrace.' 
of Germany, and as will be evident below, this is also relevant for the field of linguistics.

The Sorbs today are a national minority in a very small piece of territory called die Lausitz (Lusatia) in what was formerly the German Democratic Republic (East Germany). In English they are known variously as Sorbs, Lusatians or Wends. In this work I will follow the current style and refer to the language as Sorbian, the people as Sorbs, and the territory as Lusatia.

The Sorbs refer to themselves as Serbja (Serby in Lower Sorbian) and are the last survivors of the slavonic tribes which once occupied most of the territory between the Oder and Elbe rivers. They are Slavs, but unlike other slavic nations they have no separate political existence and are not a subgroup of any larger ethnic identity outside Germany. They want to be thought of as a Slavic people -- as distinct as the Russians, Bulgarians, or Poles -- "minor" only in a quantitative rather than qualitative sense. However, even in Germany there are many people who have never heard about the Sorbs. In fact, Western tourists in eastern Germany were known to panic when they entered the bilingual Lusatian region, believing that the Sorbian language place-name signs meant they had unwittingly crossed the border into Poland. Moreover, even scholars who have specialized in the study of the Czech and Polish languages admit to knowing little about the Sorbs, some having been taught that Sorbian was a dead language. 
The area where one can still hear Sorbian spoken currentIy begins about 50 miles south-east of Berlin and stretches approximately 55 miles to the south. It is about 40 miles across at its widest point with cottbus being the center of Lower Lusatia (so named because it is downstream on the River Spree) while Bautzen is the principal focus of Upper Lusatia.

The modern regions of Upper and Lower Lusatia correspond roughly with the areas occupied by the Milzane and Lusizi peoples, respectively, prior to German immigration during the loth century, and the historical delineation of two sorbian literary languages appears even in the earliest translations of religious works during the $16 \mathrm{th}$ and $17 \mathrm{th}$ centuries. However. it was German political development in the 17th century which finally separated these regions and encouraged the emergence of two major cultural and economic centers: Cottbus in Brandenburg/Prussia and Bautzen in Saxony. As a result, the dialects spoken in these two places were codified as the modern literary languages.

It is difficult if not nearly impossible, to find reliable information about the number of Sorbian native speakers. The Communist government of East Germany was supposedly not interested in research which could establish such data, since the results might denigrate the officially proclaimed "sozialistische Nationalitätenpolitik" by revealing the progressive assimilation of the Sorbs. According to a 1987 projection by the Institut für sorbische Volksforschung, the 
number of people who knew Sorbian was estimated at about $67,000(16,200$ of which were speakers of Lower Sorbian). However, this figure included a large number of persons with only very limited language skills, individuals who learned Sorbian in school as a foreign language, and some who did not use it at all as a language for everyday communication. Recent study indicates that it is only in the comparatively tiny Catholic area of rural Upper Lusatia (to the north-west of Bautzen and roughly defined by the villages of Radibor, Crostwitz, Panschwitz-Kuckau, Ralbitz and Răckelwitz) that one can still find predominantly Sorbian-speaking communities. According to Elle (1991), the 15,000 Sorbian speakers of this Sorbian "Kerngebiet" (core area) make up over 4 of the total number of people who actively use Sorbian today and thus could be considered native speakers. It can then be deduced that the total number of native speakers of Sorbian must be around 22,500. According to Spieß (1995) there are about 5,100 native speakers of Lower Sorbian, which leaves about 2,400 native speakers of Upper Sorbian outside the Catholic "Kerngebiet". Elle (1992: 73-79) points out that in the "Kerngebiet" $96 \%$ of the people under 35 who know Sorbian learned it at home, $95 \%$ speak Sorbian in their own families, and $76 \%$ speak only Sorbian (never German) at home. In the other (much larger) region of Lusatia only about $29 \%$ of the people under 35 who know Sorbian learned it at home, and only 9 use it today in their families. This is somewhat surprising, considering that 
over $90 \%$ of the ethnic sorbs in that region have at least some degree of knowledge of Sorbian. Also, there is a significant difference between generations, which is not the case for the "Kerngebiet": 498 of the people over 59 who know sorbian still use the language at home, while for the group between 36 and 59 this figure falls to about $22 \%$

The numbers given above show clearly that most regions of Lusatia have succumbed to German assimilatory pressure and are German dominated mixed-language territories at best. This mixture is hardly surprising since German cultural pressure has been a constant force since the loth century, though at that time Lusatia still had substantial contact with her Polabian neighbors to the north, the Bohemians to the South and Poles to the East. Continued German expansion, however, meant that by the 15th century the Sorbian speech area was surrounded almost entirely by German speakers. Despite almost 1000 years of Germanization, however, Sorbian is by no means "dead". The Sorbian publisher Ludowe nakladnistwo Domowina still publishes a daily Upper Sorbian and weekly Lower Sorbian newspaper, as well as the academic journal Letopis and the pedagogical journal Serbska Šula. There is also a significant number of contemporary popular and children's books published every year, and the academic and reference works by researchers of the Sorbische Institut in Bautzen and the Institut für Sorabistik at Leipzig University are among the most complete for any Slavic language. There are also sorbian kindergartens and 
schools, and a Sorbian-language radio station affiliated with Mitteldeutsche Rundfunk.

\subsection{Verbal Morphology of Upper Sorbian}

(Upper) Sorbian is among the more archaic of the modern slavic languages. For instance, it has preserved the use of the Dual number, and the Aorist and Imperfect tenses from Common Slavic. The present, perfective future, aorist, and imperfect are expressed synthetically. The aorist is formed from perfective verbs and the imperfect from imperfective verbs. The endings are the same for both tenses with the exception of the 2 nd and 3 rd person singular, and several grammars treat both tenses together as the simple past tense. The perfect, past perfect, and imperfective future are expressed analytically. The perfect tense is formed with the present tense of the verb byc 'to be' and the I-participle, which is analogous to old Church Slavonic (OCS). Similarly, the past perfect tense takes the imperfect of byc and the I-participle. 
Table 1: Verbal Paradigm of Upper Sorbian dzetat = 'to work' Sg.

Present/Future

1. (na) dźlam

2. (na) dzêlas

3. (na) dzela

PI.

\section{Imperfect}

dźxlach
dzelase

dॄelase norist

nadzelach

nadzela

nadzela
1. (na) dzelamy

2. (na) diel lace

3. (na) d乏elaja dzêtachmy

dzelasce

dexlachu nadzelachmy nadze laše nadzel achu

\section{Dual}

1. (na) dहelamoj

2. (na) d乏elataj/-atej2

3. (na)dzelataj/-atej

1-partictple:

masc.

Eem.
dEelachmoj

d乏飞lastaj/-astej

dॄとlałtaj/-astej nad乏elachmoj

nad乏̌laštaj/-aštej

nadıxlastaj/-astej

sg. (na)dzelal (na)dzelala (na)dzelalo

P1. (na) dzelali

Dual (na) dexlaloj

byc $=$ 'to be'

Preeent

Imperfect

\begin{tabular}{lll}
\hline $\mathbf{8 g} \cdot 1 \cdot$ sym & bexch \\
$2 \cdot$ sy & bè (š) \\
$3 \cdot$ je & bè (̧e)
\end{tabular}

P1. 1. smy

bèchmy

2. sEe

běsce

3. su

bechu

Dual 1. smoj

2. staj/stej ${ }^{3}$

běchmoj

3. $\operatorname{staj} /$ stej

bestaj/-štej

bextaj/-rtej

Virile vs. non-virile distinction.

Virile vs. non-virile distinction. 
Examples of Perfect:

ja sym dexlala

mój smój džlałoj
'I have been working'

'we two have been working'

\section{Bxamples of Past Perfect:}

ja berch dzelala

mój běchmoj dzelaloj
'I had been working'

'we two had been working'

Building on the discussion in Chapters 2 and 3 we can see that the Upper Sorbian verbal paradigm meets the morphological uniformity condition, since all forms are consistently derived. Thus, Sorbian should license null subjects. It would also seem that the "richness" of the Sorbian verbal agreement system can easily compare with that of the other West (and South) Slavic languages. In Chapter 3 we established that Czech (as a general representative of West slavic) qualifies as a canonical null-subject language. Consequently, we would expect the same to be true for Upper Sorbian. Also, since Common Slavic was a pro-drop language, and the Sorbian verbal system seems to preserve the Common Slavic situation as well as any of the other Slavic languages, the expectation that Sorbian is a null-subject language is reinforced. 


\subsection{Gramor ve. Reality}

Upper Sorbian has personal pronouns for the singular, plural, and dual.

Table 2: Personal Pronouns of Upper Sorbian

$$
\text { 1. pers. 2. pers. }
$$

\begin{tabular}{lll}
\hline sg. & ja & ty \\
Pl. & my & wy \\
Dual & moj & wój
\end{tabular}

\begin{tabular}{llll} 
& \multicolumn{2}{c}{ 3. pers. } \\
& masc. & & \\
& & \\
\hline sg. & won & wona & wono/wone \\
P1. woni, wone & \\
Dual wonaj, wonej &
\end{tabular}

The dialectal distribution between the two neuter forms wono and wone will be discussed in Chapter 5 . The plural form woni is used to refer to males, whereby one individual in the group is sufficient to use this form of the 3 rd person plural pronoun. The form wone is used elsewhere, and can refer to people, animals and inanimate things. The same distinction is expressed in the dual.

According to current school grammars and older influential grammars such as Jordan (1841), Schneider (1853), Liebsch (1884) and Kral (1895), personal pronouns in Upper Sorbian should only be used in emphatic contexts. Sewc (1984: 117), for instance, writes: 
Na rozdžl wot némskeje a ruskeje rexe wuziwa so w serbšćinje forma personalneho pronomena pi werbach jako subjekt jenoz we wobmjezowanym rozsahu. Zwisuje to z tym, zo charakterizuja same wosobowe kóncowki hizo jasnje dosć wotpowędnu wosobu.

' In contrast to German and Russian, the personal pronouns in Sorbian are more restricted in their use. This is connected to the fact that the personal endings themselves already indicate the corresponding person quite clearly.'

This is certainly reminiscent of the description of personal pronoun use in null-subject languages such as Czech or SerboCroatian discussed previously.

In most of the older grammars the authors are even more outspoken about the lack of overt pronoun use in Upper Sorbian. For example, Jordan (1841: 169) writes:

Da die Personen an dem Ausgange des Verbums hingănglich erkennbar sind, so werden die persönlichen Fürwörter ja, ty, wón, moj, woj, wonaj, my, wy, woni nur dann gesetzt, wenn die Person besonders ausgezeichnet werden soll."

Similarly, Schneider (1853: 250) writes:

... die persönlichen Fürwörter: 'ich, du, er, wir, ihr, sie' werden im Wendischen nur dann gesetzt, wenn ein besonderer Nachdruck darauf ruht, oder wenn ein Gegensatz angezeigt werden soll. Z.B. Ja sem to pisaw, nic té ich habe das geschrieben, nicht du. s $^{2}$

$4 \quad$ 'Since the person is sufficiently recognizable from the verb ending, the personal pronouns ja. $t y$, wón, moj, woj. wonaj. my, wy, woni are only used if the person is to be especially marked.'

s '...t the personal pronouns: 'I, you, he, we, you, they' are used in Sorbian only if they carry a special emphasis or if they indicate a contrast. For example, Ja sem to 
Liebsch (1884: 27/28) gives the same rule even more explicitly:

Dieses Verhăltnis ... wird im Wendischen ăhnlich wie im Lateinischen und Griechischen durch die Personalendungen des Verbum bezeichnet. Deshalb ist die nochmalige Bezeichnung desselben durch die Personalpronomina durchaus überflüssig und nur dann notwendig und gestattet, wenn wir das subjekt aus irgend einem besonderen Grund nachdrucksvoller hervorheben wollen ... Das ausdrückliche Bezeichnen der Person durch das persönliche Fürwort im Wendischen ist daher nur ein Germanismus. ${ }^{6}$

Finally, Kral (1895: 58) writes:

Die persönlichen Fürwörter als Subjekte werden nur dann gesetzt, wenn auf denselben ein gewisser Nachdruck liegt, oder wenn sie im Gegensatze stehen.?

Thus our expectation that Upper Sorbian is a canonical null-subject language seems to be met. This is confirmed by the following example from contemporary literary Upper Sorbian. The excerpt is taken from Jurij Koch's novel Ha lecala je módra wróna published in 1991.

(* indicates all places where a subject is "missing")

pisaw, nic ty ('I wrote that and not you').'

- This relationship ... is expressed in Sorbian. very much as in Latin and Greek, by the personal endings of the verb. Therefore, the additional expression by personal pronouns is completely superfluous, and only necessary and permitted if the subject is supposed to be stressed more amphatically. ... The explicit marking of the person by a personal pronoun in Sorbian is thus just a Germanim.'

1 'Personal pronouns as subjects are only used if they carry a certain emphasis, or if the are used to contrast.' 
Moja maćerna rę je serb̧̌́ina ... Z tutej ræxu sym * wotrost1. " njemóź so wjace wot njeje džliz, tez nic, hdyz bych \# to chcyl. \# Njejsym sej ju wupytal. * Bé tu hizo, hayz *óndzech.

'My mother tongue is Sorbian ... With this language I grew up. I cannot part from it any more, not even. if I wanted to. I did not select it. It was here, when I arrived.'

However, Upper Sorbian dialects provide us with contradictory data. Published transcripts of dialect texts reveal a surprising level of overt subject pronoun use, despite the fact that the dialects have the same rich person/number system as the standard language. The following are some typical examples. Sentences (1-3) are taken from Faßke and Michalk (1989), while (4) and (5) are from Michalk and Protze (1974).8

(1) a do pównoce smó mó khodzili and till midnight aux $x_{1 p}$ we went ${ }^{9}$

'wo walked until midnight'

(2) tuijs sej woni zane(j) rade wejdzili nejsu also refl they none advice knew neg-aux 3 pl 'and since they didn't know what else to do'

(3) ale fa sn něk tam wele moli ribach bow but I aux ss $_{\text {sen }}$ there many times mushrooms was a ja (ja)c jich nico widziw nejsym and I more they $y_{\text {sm }}$ nothing saw not-aux isg $_{\text {s. }}$ 'but I often used to go there for mushrooms and I didn't see any of them anymore'

- Some of these examples contain dialect forms which are not found in standard Sorbian.

9 The notation "aux ${ }_{1 s g}$ " etc. assumes present tense of the auxiliary byc unless otherwise noted. 
(4) woni praja, woni dyrbja tom knjez Sminderej, zo they say they must that $\mathrm{mr}_{\text {du }}$ Sminder $_{\text {dx }}$ that woni, hejzo jich njepuša, woni dom njepóndzeja. they if them not-admit they home not-will-go dojz joh woni njendza widzec until him they not-will-go see

' they say thoy must see Mr. Schminder, that thoy. if they are not admitted, they won't go home, until they have seen him'

(5) hale kóży mól pak bóch fa cedlku płitykwa;

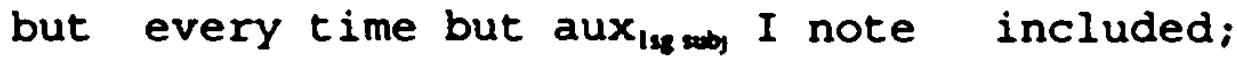
ja sym jare rjenje pisawa I aux $_{1,}$ very nicely wrote 'but every time I included a small note; I wrote very nicely'

An interesting descriptive discussion of the problem is provided by Faska (1964). He concludes from an analysis of a large number of recordings of speakers from various regions that the traditional "null-pronoun rule" conflicts with actual use in Sorbian. In fact, in the sample he analyzed, there were more instances of overt subject pronouns in tensed clauses than instances of zero pronouns. It is not surprising that overt pronouns are used in emphatic and contrastive contexts in spoken Sorbian. However, Faska (1964) also determines other environments where spoken Sorbian more-or-less consistently uses an overt (non-emphatic) pronoun, and it is these instances, illustrated in the examples (6-8), which are of particular interest to us. ${ }^{10}$ contain dialect forms which are not found in standard Sorbian. 
(6) If direct or Indirect speech is being introduced:

a. "ja so nito njeboju", je wón rjekl

'I don't fear anything', he said

b. a ja njebech tak hlupy, ja sym płeco prajil, zo ja dale na dzélo póńdu do mèsta

'but I was not so stupid, I usually said,

that I would keep on going to town to work'

c. woni su mi prajili, stó je to byl, ale ja sym to zabyl

'they asked me what that was but I forgot'

(7) If the mntrix subject is a demonetrative pronoun:

a. ton te dwaj abo tłi dny spac njemózese, dokelz wơn dyrbjeకe wక̌ widzeć a wjesć

'that one couldn't sleep for two or three days, because he had to see and lead everything'

b. a ta je so tak wustróala, zo je mona chroma wostala

'and thet one got so startled that she stayed lame'

(8) If the oubfect of the matrix clauee ie a fuIl NP: a móf nan je prajil, zo bď́e wón přećiwo Vogtej hic 'and my father said that be would go against the overseer'

In most other environments lexcept for imperatives, impersonal sentences, and sentences with 3 rd person arbitrary reading" which strongly prefer or even require the subject to be zerol the pronoun is sometimes used and sometimes not. No general pattern is readily apparent, and the choice seems to

1 See also section 4.3. For the possible use of overt woni in arbitrary plural constructions. 
depend on a variety of factors, (including the speaker and the rhythm of the sentence). According to Faßke, of the 190 examples he examined which were not instances of one of the environments above, 75 had a zero subject, while 115 had an overt subject. He thus concludes that it is not necessary to prohibit the use of overt pronouns in the literary language categorically ("njetrěbne je, wuziwanje personalnych pronomenow w literarnej rexi tak kategorisce zakazaen").

Jent (1959) is mainly concerned with the position of the auxiliary and the l-participle in Sorbian. However, he also provides some interesting data about the use of personal pronouns in subject position. His investigation is based on a large sample of native speaker recordings. The most important results with respect to our topic are the following. The forms of byt are quite consistently treated as enclitics, and colloquial speech (Iudowa rex) does not put the auxiliary in initial position except in yes/no questions. The auxiliary is typically preceded by a personal pronoun, as the following examples, taken from Jent (1959), illustrate:

(9) Ja oym tam wjele moli byl

I aux $_{1 y}$ there many times was

'I have been there many times'

(10) won fe sej tola myslil, zo wón te he $\operatorname{aux}_{3 z s}$ refl though thought that he this šerjene wjedźe ghost leads

'he however thought that he leads the ghost' 
The number of instances where the auxiliary is found in initial position is low. According to Jent this is mainly the case when people try to make a conscious effort to speak "correctly", and therefore without pronominal subjects. Example (11) below reveals this "extra" effort since virtually all sorbs normally use German numbers in spontaneous speech.

(11) sym rod乏ena w Jaseńcy sydomadwaceteho septembra d乏ewjatnace stow a wósomasydomd乏́esat

'(I) was born in Jeßnitz on September $27,1978^{12}$

One individual seemed to use the construction with the auxiliary in initial position intentionally as a stylistic device of terseness, perhaps comparable to the "diary-style" mentioned in Chapter 2.

If something other than the subject is in initial position, the subject pronoun is still usually lexicalized, following the clitic verb form, as shown in (12-14).

(12) tam aym ja bydlil

there auxisg I lived

'I lived there'

(13) a netk stej wonej wjecor sloj and sometime aux 2 wad they dur evening went

'and sometimes they both went in the evening'

(14) za sport sym ja wězo płeco zajim mêl

for sports aux ${ }_{1 s s} I$ indeed always interest had

'for sports I surely have always had an interest'

12 This must be a mistake, since the recordings were made before 1959. The speaker probably meant to say 1878 . 
Jent points out that the few instances without personal pronouns are produced by people who have jobs in the public sector and are more likely to try to conform to the school style in which they were trained. Even those individuals usually start using personal pronouns more frequently further into the recording when their style gets more lively and they become less driven to try to produce "correct" Sorbian.

With respect to subordinate clauses Jent points out that there, too, personal pronouns are used more frequently than they are omitted. In his sample the ratio came out $647: 367$ in favor of lexicalized personal pronouns. Below are two of the many examples cited by Jent:

(15) hdyz sym fa najprjedy sluzil, da sym ja when aux $_{\text {isg }}$ I first served however aux isg I kolosal lochki byl very light was ' however, I was very light when I first served'

(16) hdyz je wón wumrêl, to ja wĕm when $\operatorname{aux}_{338}$ he died that I know 'I know when he died'

It should be emphasized once more that in Sorbian the use of overt pronouns is not obligatory, in contrast to German. Even though the frequent use of overt pronouns in Sorbian is usually blamed on German influence, there are some examples 
where Sorbian speakers omit pronouns in German, which further supports the claim that pronouns in Sorbian are optional. ${ }^{13}$

There might even be evidence within the literary language itself that the very limited use of overt pronouns is an artificial phenomenon, induced by prescriptive grammars and not in line with the real language. It is well known that clitics in some languages occupy the second position in the clause, the so-called Wackernagel position. ${ }^{4}$ According to Jenc (1959) and Michalk (1970) the present, past and conditional parts of the auxiliary verb byc belong to the class of clitics and as such should not be found in the first position of a clause, assuming that Sorbian is a Wackernagel language. ${ }^{\text {is }}$ As we have seen above in the discussion of Jent (1959), that expectation is

13 Michalk (1977) cites the following two examples for missing personal pronouns in German under the influences of Sorbian:

(i) \# bin mit in die LPG eingetreten (missing Ich) '(I) have also joined the cooperative'

(ii) Kuhstall ist noch nicht so, wie \# sein muß (missing ex) ' cowbarn is not yet such as (it) must be'

14 If there is more than one clitic, there are rules for the positioning of those clitics relative to one another. In Sorbian, according to Michalk (1965b), the relative ordering is the following:

particle/byc/dative/accusative/nominative
hat drje
sym ci je
if part.
auxise youter them $_{\text {mox }}$
ja tez prawje
wumy 1
'if I indeed washed them the right way for you'

15 The status of the forms of byc as enclitics is not absolute. In interrogative clauses the auxiliary is found regularly in first position both in colloquial speech and literary style, where it might be analyzed as proclitic. 
borne out in normal spoken Sorbian. Typically they are in second position preceded either by a nominal subject NP or by the personal pronoun. However, in the literary language there are many examples with an initial auxiliary. ${ }^{16}$ Jent attributes this phenomenon to the fact that writers feel obliged to comply with the rule of the official grammar that personal pronouns in general must not be used. Example (17) with the conditional form of byc is taken from Koch (1991), and (18) and (19) are taken from the newspaper Nowa Doba as cited by Jenc (1959).

(17) bych sej samomu zakladne doziwjenje aux $_{\text {iss subj }}$ refl $l_{\text {da }}$ self $_{\text {da }}$ basic experience pokradyl; bych je pódla sebje stejo wostajil deprived; aux iss soy $_{\text {it }}$ next myself standing left ' (I) would deprive myself of my basic experience; (I) would just turn my back on it'

(18) sym prajil, zo doma wostanjetaj aux ${ }_{1 \text { sepres }}$ said that at-home will-stay 3 dw

'(I) said that the two of them will stay at home'

(19) br nam tez najnowše nowiny sobu prinjes! aux $_{3 s g \text { imper }}$ us too newest paper self brought

' (he) had also brought the newest papers with him'

Interestingly, even the puristic grammars of the 19th century still describe sentences such as the ones above as ungrammatical. Liebsch (1884: 228), for instance, writes that sym, sy, including De Bray (1963), write that auxiliary verbs in Sorbian are not clitics, in contrast to languages like Czech or Serbo-Croatian. 
je. smój, staj, stej, smy, sce, su must never be in the initial position in a sentence.

\subsection{Application of null-subject diagnostics}

Thus far we have seen that there is a contradiction between the normal spoken language and the exhortation found in various Sorbian grammar books to omit overt subjects. From this it is clear that we should at least be very suspicious about the pro-drop status of Sorbian. We will now apply the set of three diagnostics introduced in Chapter 2 in order to independently determine the status of Upper Sorbian with respect to null-subject characteristics. For the reasons discussed in Chapter 3 for Russian, this investigation will focus on the interpretive possibilities associated with overt subjects. The three diagnostics are repeated here as (20).

(20) The following holds true for null-subject languages:

a. Overt subjects are stylistically marked.

b. Overt subjects cannot function as bound variables.

c. overt subjects cannot be arbitrary in reference.

The linguistic data presented in this chapter come from various sources, which should improve reliability. I use examples based on published transcripts of spontaneous speech. examples cited in published articles, Sorbian sentences which I elicited from native speakers on the basis of German source texts, and Sorbian examples constructed by me and judged by native speakers. I conducted most of my fieldwork in the 
rural area north-west of Bautzen which was previously referred to as the "Kerngebiet". Since there are only an estimated 2,600 native speakers of Upper Sorbian dispersed outside this area, it was impracticable to undertake an exhaustive search. With respect to the null-subject criterion in (20a), the rampant use of unemphatic pronouns illustrated in the previous section strongly suggests that Upper Sorbian is not a canonical null-subject language. My fieldwork showed the same high level of overt pronoun use.

A similar conclusion can be drawn from the appearance of the overt won 'he', wona 'she' and woni 'they' in the bound variable contexts in (21a-i). Example (21) is taken from a literary text and cited by Faßke (1981). Examples (21b-g) were constructed by some informants when they were given the corresponding German sentences. All other informants accepted $(21 b-g)$ with a coreferential or bound reading of the pronoun in the subordinate clause when the sentences were given to them in Sorbian. Sentence $(21 \mathrm{~h})$ was previously listed under (8) to illustrate one of Faßke's (1964) overt pronoun rules. In terms of our diagnostics, Faßke's rule means that a personal pronoun is usually realized phonologically if the subject antecedent of the matrix clause is a full NP, thereby directly contradicting the null-subject criterion (20b). Example (21i) is a sentence which Jent (1959) uses in the explanation part of his article. Technically speaking, only (21b-d) are true examples of bound variables. However, criterion (20b) also 
applies to structures where the QP is replaced by a referential NP (cf. section 3.1.2).

(21) a. Feliks njepytny, zo wón hižo hodźinu Feliks not-realized that he already hours po mesce honja

through town ran

'F. didn't realize, that he had already been running through town for an hour'

b. koży nan mysli, zo wón mudreho syna ma every father thinks that he smart son has 'every father thinks he has a smart son'

c. kózdy prołer so nadzija, zo wón skoro zbohatnje every beggar refl. hopes that he soon become-rich 'every beggar hopes that he will soon be rich'

d. kódy student sej mysli, zo wón jedynku dóstanje every student refl thinks that he $A$ will-get 'every student thinks that he will get an $A$ '

e. Serbja su hordzi, zo woni swoju rex Sorbs aux $_{3 p \text { t }}$ proud that they their language have 'Sorbs are proud that they have their own language'

f. Jana je prajila, zo chce wona rady kupae hic Jana aux $_{3 x_{8}}$ said that wants she gladly swimming go 'Jana said that she would gladly go swimming'

g. Jana lubuje toho muza, na kotrehoz je so wona Jana loves that man at whom $\operatorname{aux}_{3 s g}$ refl she pł̌ed dźesac letami wudala ago ten years married

'Jana loves the man whom she married ten years ago'

h. a mój nan je prajil, zo bdźe wón překiwo

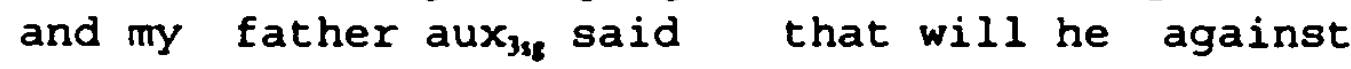
Vogtej hic overseer go

'and my father said that he would go against the overseer' 
i. Ale tež Grofa staji, hdyž wón ziwiš rěci, but too Grofa puts when he lively speaks personalny pronomen. personal pronoun 'but also Grofa uses, when he speaks lively, a personal pronoun'

The application of the third null-subject criterion produces the same results, although perhaps less obviously so. While I did not observe the use of overt woni in spontaneous speech, there were some informants who used this construction when translating German sentences with arbitrary reference into Sorbian. However, the main point is that most informants, especially those without literary training, agreed that the presence of the overt 3 rd person plural pronoun does not force a referential reading of the pronoun, in contrast to "true" null-subject languages such as Czech. Examples of overt pronouns with arbitrary reference are given below.

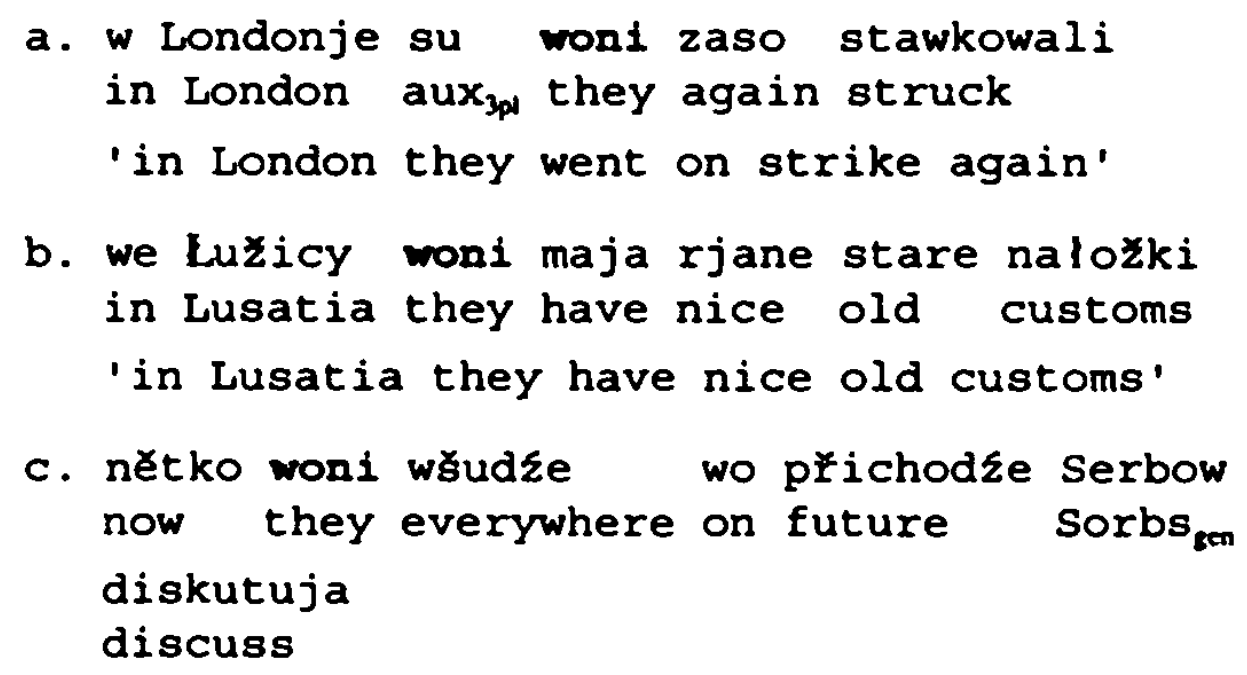

'nowadays they are talking everywhere about the future of the Sorbs' 
d. něhdy su woni skromniło ziwi byli hat dzensa once aux $_{3 p}$ they modestly living were than today 'once they used to live more modestly than today'

e. na tutej kupje woni hizo 500 let francosce on this island they already 500 years French reca speak

' they have been speaking French on this island for 500 years'

f. na wikach wonl sad płedawaja at markets they fruit sell

'they are selling fruit at the market'

g. w Sewjernej Americe wonl jendzelsce rexa in North America they English speak 'they speak English in North America'

I therefore conclude that Upper Sorbian is not a canonical null-subject language. This raises two main questions:

A. Why do the authors of most grammars try to describe Sorbian an a null-aubject language (1n contrant to the actual opoken language) by strongly discouraging, if not oren prohibiting, the use of overt non-emphatic pronouns?

B. Why is Sorblan different from the other West slavic (and South Slavic) languages?

The next section is devoted to the first question, while section 4.6. will focus on question $B$. 


\subsection{Pronouns and puriam}

I agree with Faska (1964), who assumes that the pronoun-prohibiting rules of the traditional grammars were actually not formulated on the basis of the Sorbian language, but instead under the influence of czech. Since the literary norm is based on the linguistic works of the middle and late 19th century, it is obvious how the pronoun prohibition rule made its way into current school grammars as well.

This seemingly small detail of how to use overt pronouns can be seen as reflecting a much larger phenomenon when viewed in historical context. In the mid-19th century there was a strong Sorbian national movement known as the serbske narodne wozrodźenje ('Sorbian National Rebirth'), which led to a wide application of the literary language to secular situations. The Sorbs understood themselves to be part of the larger slavic family of peoples, in keeping with the "Panslavism" of this period, and looked especially to their Czech neighbors as a guide. This was accompanied by the phenomenon of "purism", aimed at complete removal of all foreign, and especially German. elements from the Sorbian literary language. New lexical needs were satisfied by the introduction of loan-words and loan-translations from other slavic languages, especially Czech. Similar attempts were aimed at a removal of certain "non-Sorbian" morphological and syntactic phenomena from the literary language, most of which were attributed to German influence. 
One example of these "alien" elements, which can be used to date the rise of purism fairly precisely (within 10 years), was the use of the demonstrative pronouns ton, ta, te in the same distribution as the definite article in German. As Lotzsch (1968) points out, analyzing different descriptions of the use of the definite article in Sorbian, Seiler's (1830) grammar is still free from puristic biases. Seiler tries to give an objective analysis of the use of the demonstrative pronoun as the definite article in Sorbian. Jordan's (1841) grammar, on the other hand, may be the first puristic work of Sorbian Iinguistics. He refers to the use of the definite article in Sorbian as "Abnormalität" and "grundlose und widersinnige Nachahmung des deutschen Idioms, die dem Charakter und dem Geiste der slawischen Sprachen rein zuwider lăuft" (Jordan 1841: 138). Schneider (1858: 8) calls the definite article in Sorbian a "Danaergeschenk der Deutachen". 17

Similarly, the use of overt pronouns in Sorbian has often Ibeen blamed on German influence, although this is not necessarily the case. We will return to the question of why Sorbian

17 The use of demonstratives as definite articles is still discouraged for the literary language but widely spread in spoken Sorbian. The following sentences are examples from colloquial Sorbian, taken from Michalk and Protze (1974).

(i) ja sym slyšl, zo jo wón sej tu nohu zlamal ich habe gehört, daß er sich das Bein gebrochen hat

'I heard he broke his leg'

(ii) te ludio su tola wsitcy wonka na namésee die Leute sind alle draußen auf dem Anger 'the people are all outside on the village green' 
is not a pro-drop language in more detail below. Even if the use of overt pronouns proves to be genuinely Sorbian, language purism would have influenced this phenomenon because it appeared to be of German origin, simply because it was different from the pro-drop Czech (and Polish) neighbors. This turning to other Slavic languages to cleanse their own was a characteristic trait of the Sorbian purists.

Language purism in general is very prescriptive in character, and it contributed to a gap between the literary language and spoken language in Sorbian. This gap has only widened. since this crusade did not stop in the past century, unlike other puristic movements. Jenc (1959: 43) refers to this when he accuses contemporary writers of clinging to grammatical norms of other Slavic languages as if "hypnozowani" ('hypnotized'). According to Jent (1964: 1965), the difference between written and spoken Sorbian today is such that one might rather speak of two different languages instead of two different forms of the same language. He points out that there are only a few differences between the colloquial language today and the written language before the middle of the 19th century. We can thus assume that formerly there was no difference between spoken and written language and that it was (and still is) the search for an "ideal" and "pure" Sorbian which has been moving them further apart by prescribing archaic and artificial norms for the written language. In several articles Jent appeals to the Sorbian writers of today's literature 
to overcome this schism and stop their "wěne bojazliwe hladanje na druhe ræ̣̌" ('constant fearful look at other languages'). As Luther would have said, "man muß dem gemeinen Mann aufs Maul schauen" ('one should look at the common man's mouth') to codify a language so that it can function as a widespread means of communication.

The results of purism with respect to the use of personal pronouns in the written language can be illustrated by the following Biblical passage as it appeared in 1728 and 1896 versions, as cited by Jenc (1964: 252).

(23) a. Matthew 25:42,43 (1728, Richter (ed.))

Płetoz ja sym hlódny byl a wy njejsce mi jessć dali. Mi je so pit chcylo a wy njejsce mi pić dali. Ja sym hóst byl a wy mje njejsće hospodowali; fa sym nahi byl, a wy mje njejsce wodzéwali; ja sym chory a jaty byl, a my njejsće ke mni pohladali.

b. Matthew 25:42,43 (1896, Luscanski and Hornik)

Płetoz buch hlódny, a njedaš́e mi jêsć; buch lačny a njenapojisće mje. Bæch cuzy, a njehospodowaśće mje; nahi a njewoblekaše mje; khory a w jastwje a njewopytasce mje.

There are nine overt personal pronouns in the version of this passage translated in 1728, none of which are present in Lustanski and Hornik's 1896 version in (23b). We have to assume that this change happened under puristic pressure since there are no indications that Sorbian had really become prodrop (again). 
Michalk (1972: 91,92) gives some interesting numbers with respect to the sudden decline of the use of overt pronouns in successive versions of Bible translations. The various Catholic translations seem particularly relevant since these are all based on the Latin Vulgate, i.e. direct influence from German can be excluded. Swetlik (Perikopen ${ }^{18}$ 1690) uses 20 personal pronouns in Matthew 2:2-18 which are not present in the Latin. In the 1750 pericopes, which differ only slightly from Swetlik's version, there are still 17 such pronouns. In the pericopes from 1848 this number is reduced to 7, in Buk's (1862) translation there are only 3 left, and they are all stricken from Luscanski and Hórnik's (1896) version. ${ }^{19}$

In the 1896 version we find that there are personal pronouns only in those places where they correspond to personal pronouns (1st and 2nd person), demonstratives or qui in the Latin version. Below are some examples:

18 Pericopes are selections of various Bible passages.

19 The protestants translated their version of the Bible from Luther's German text. Interestingly enough, the number of non-emphatic personal pronouns is actually lower than in the Swetlik translation. In Frencel (1670) there are 13 personal pronouns in Matthew 2:2-18 which have no correspondence in the Hórnik/Luscanski version. This number stays constant in the 1728 and 1823 versions, though in slightly different distribution. Obviously, the protestants were not as concerned about "purifying" their Bible, because the 1905 translation still has the same 13 personal pronouns. It is not until 1960 that we note a drastic drop in this number from 13 to just 1 , apparently due to a post-1945 puristic movement. 
(24) Matthew 3:11

ego quidem baptizmo vos in aqua ..

ja drje kł̌cu was $z$ wodu

(25) Matthew 2:13

qui cum recessissent ..

Hdỹ bexchu woni wotešli

(26) Matthew 2:5

at 1111 dixerunt ei

woni pak prajachu jemu

We have already seen Jordan's account of overt subject pronoun use in Sorbian in which personal pronouns are only used in emphatic contexts, as is typical for czech. Only ten years earlier, however, Seiler states the complete opposite:

Die persönlichen Fürwörter werden zum Zeitworte erfordert ... (Seiler 1830: 113).20

He then lists rules by which personal pronouns are omitted:

Gebraucht und wiederholt werden sie nicht: a) wenn das Subjekt oder sein Pronomen im vorhergehenden Satze .... genannt worden ist ... b) im Imperativ und in Gemeinplätzen, wo man eine bestimmte Person geradezu nicht meint. (ibid) ${ }^{21}$

'The personal pronouns are required with the verb.'

21 'They [personal pronouns, ML] are not used and repeated: a) if the subject or its pronoun ... was mentioned ... in the previous sentence ... b) in the imperative and in general meaning where one does not refer to a certain person.' 
It seems that Seiler's description is certainly closer to the real situation found in spoken Sorbian today. It also gives a more realistic account of the use of pronouns in the Sorbian language of his time. For instance, in the preface to his new political newspaper serbski powèdar a kurerr, first published in 1809, J. B. Dejka uses 10 (non-emphatic) overt subject pronouns $(5 \times j a ; 2 \times w y ; 3 \times m y)$ and only uses a zero pronoun twice. 22

The influence of the Czech language on the repudiation of overt pronouns in Sorbian is even more likely when one takes into consideration the fact that three of the authors of the aforementioned grammars studied and worked in Prague at the Serbski seminar ('Sorbian Seminary') at the time they wrote their grammars, i.e. Jordan (1831-38), Liebsch (1880-83) and Kral (1879-89). Lustanski, the co-author of the 1896 Bible, was head of the Serboki seminar in Prague from 1877 to 1894 .

\subsection{Why is Sorbian not a canonical null-anbject language?}

The conclusion that upper Sorbian is not a pro-drop language in the classic sense raises the question of why Sorbian is different from canonical null-subject languages, such as Czech and Polish. As we have seen in (1), the verbal paradigm of Sorbian is morphologically uniform, and null subjects should 
thus be licensed. ${ }^{23}$ So from the perspective of a licensing/identification approach to the problem the following question presents itself: why is the identification of referential subjects in Sorbian blocked and Sorbian thus prevented from being a canonical null-subject language? Two possible analyses are presented below. These are then followed by a discussion of the limitations of a "pure" licensing/identification approach to the problem and a presentation of a third, alternative analysis.

\subsubsection{Identification and the number of oyncretiams}

A possible explanation for why Sorbian is not a null-subject language might be formulated in terms of Roberts's (1993) restriction on the number of syncretisms tolerable for successful identification.

Roberts adopts Rizzi's (1986) licensing criterion for null subjects:

(27) If $X^{0}$ is the licensing head of pro, $X^{0}$ can assign Case to the position occupied by pro.

As pointed out by Roberts $(1993: 18)$, it has been proposed that structural case can be assigned in two different configurations, government or agreement, as illustrated below. 
(28) Case assignment under government:
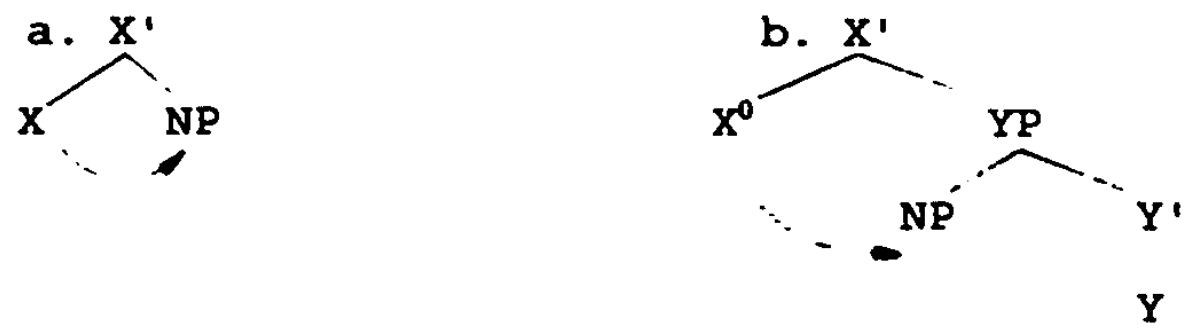

(29) Case assignment under agreement:

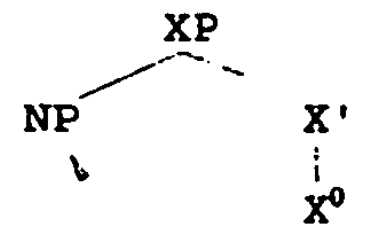

There is assumed to be a nominative assignment parameter. according to which nominative can be assigned under government or under agreement. Nominative assignment under government presupposes movement of the inflected verb into $C$ position to produce the configuration shown in (28b). This is typical for V-2 languages, such as German, as illustrated in (30).24

(30) Peter liest den Roman. 'Peter reads the novel'

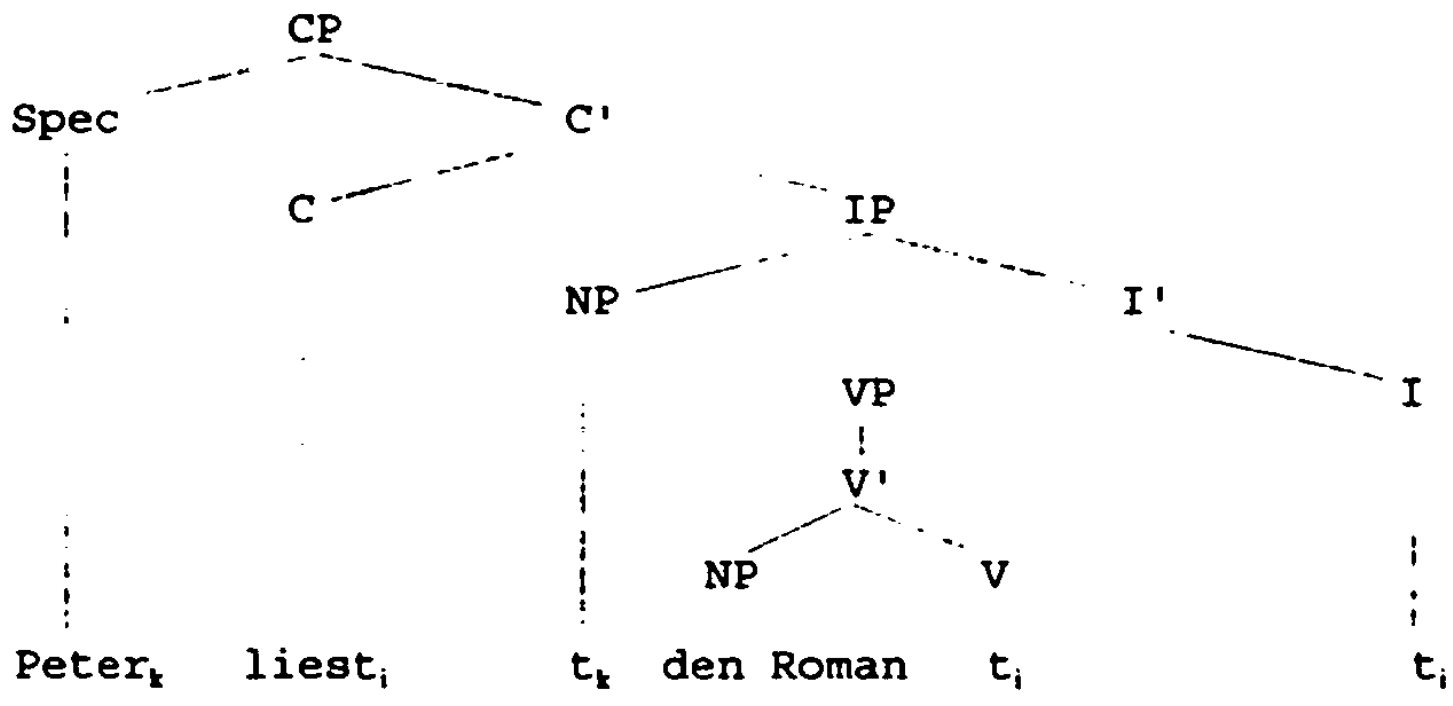

24 See fn. 13 in Chapter 2 for a possible explanation of why German is not a pro-drop language. 
Nominative assignment under agreement, on the other hand, is normal spec-head agreement between $A G R$ as the head and pro in the specifier position of AgrP.

The identification of referential pro (which Roberts calls "content licensing") can happen in two different ways: by "functional richness" and by "formal richness". The precondition on formal richness, according to Roberts, is a morphologically uniform paradigm where an agreement slot is available throughout. ${ }^{2 s}$ Functional richness, on the other hand, is defined in terms of a restriction on the number of syncretisms tolerable for successful identification, and it allows for one syncretism in the paradigm. Functional richness, as opposed to formal richness, is also compatible with a zero ending (and since the zero ending can be the syncretism, there is actually the possibility of two zero endings in a functionally rich paradigm as long as all the other endings are distinct).

We have discussed above how the Sorbian paradigm, and in fact the verbal paradigms of all slavic languages, fulfill the morphological uniformity condition, which is treated as the licensing condition within the Jaeggli and Safir system, as opposed to Roberts, for whom it is one of the two possible conditions for Identification. If we want Roberts's system to

25 In contrast to Jaeggli and Safir's morphological uniformity hypotheses, Roberts's formal richness pertains only to paradigms with consistently derived inflectional forms and not to languages which do not have agreement morphology. 
work we must find a reason why formal richness, i.e. morphological uniformity, is not relevant for identification in Slavic.

It is crucial that a language may not automatically avail itself of either of the two mechanisms of identification. In this context, Roberts (1993: 207) proposes the following general principle, (mainly to account for the loss of preverbal pro in French after a change in the nominative assignment parameter as summarized below).

(31) If Agro formally licenses pro only under agreement, then Agr must be functionally rich.

Roberts's theory is based on the history of French, which once had null subjects, even though pro was only found in certain syntactic environments, unlike in modern Polish or Italian, for example. He shows how the loss of null subjects in French can be linked to the change of a single parameter, namely the nominative case assignment parameter, in conjunction with principle (31). Old French was a null-subject language in the sense that referential null subjects were possible in V-2 contexts, i.e. postverbally under government by $A G R$, which also means that nominative was assigned under government. Identification in early old French was possible because the verbal paradigm was functionally rich. A major restructuring took place in the 12 th century, and as a result the paradigm ceased to be functionally rich due to the large 
number of syncretisms. However, at the same time the verbal paradigm became formally rich instead. Thus, despite the loss of functional richness, French remained a null-subject language for a time, as long as nominative assignment under government was available. Middle French saw a change with respect to the occurrence of null subjects in that the number of contexts in which null subjects were allowed actually increased -- specifically null subjects could also occur preverbally. According to Roberts this was possible because nominative assignment was no longer restricted to government configurations, but instead expanded to include the agreement context as well. Middle French had a morphologically uniform paradigm and content licensing was accomplished via formal richness.

The relatively sudden disappearance of null subjects in the 17 th century is attributed by Roberts to the fact that nominative assignment became restricted to the agreement configuration, i.e. nominative cannot be assigned under government. At this point, post-verbal null subjects are directly excluded since they cannot be licensed anymore. What about pre-verbal null subjects though? According to Roberts, as a consequence of the change in the nominative assignment parameter, null subjects in a language like 17th-century French can only be identified by a functionally rich paradigm, following principle (31). Formal richness does not suffice any more. 
However, the verbal paradigm of French does not fulfill the functional richness criterion and identification fails. ${ }^{26}$

In order for Roberts's approach to be at all applicable to identification in Sorbian we have to make the assumption that the nominative assignment parameter is set to "agreement only".27 In other words pro, is formally licensed under agreement only, and for referential subjects to be identified we need a functionally rich paradigm, while formal richness (i.e. morphological uniformity) is not applicable. A tolerance of one syncretism for functional richness, as defined by Roberts, may indeed be necessary to incorporate some slavic null-subject languages. For example, there is a syncretism in Bulgarian between 2 nd and $3 \mathrm{rd}$ person singular endings in both the imperfect and the aorist, as illustrated in (32) and (33).

Sprouse and Vance (1994) point out a rather counterintuitive point of Roberts's analysis. Middle French was a language which had nominative assignment both by agreement and by government. However, assuming the validity of principle (31) and taking into account that the paradigm was only formally rich, null subjects in the agreement configuration could only be licensed because of the instances where pro was licensed in the government configuration.

27 This assumption is far from universally held. At first glance one might try an analysis, according to which Slavic languages have different settings for the nominative assignment parameter and thus different ways of identification available to them. However, the setting of the nominative assignment parameter makes no difference for the canonical null-subject languages, since they all seem to have both formally and functionally rich paradigms. For Russian and Sorbian, on the other hand, the setting of this parameter is crucial. King (1993) proposes nominative assignment under government for Russian. However, this would make formal richness relevant for identification, with the undesirable result that Russian should be a canonical null-subject language. 
(32) jadese Imperfect: 'eat' 2 nd/3rd sg

(33) jade Aorist: 'eat' 2 nd/3rd sg

Note that this situation does not count as two syncretisms, presumably, because they occur in different tenses. To accommodate these data we would need to revise Roberts's syncretism criterion slightly:

(34) A verbal paradigm is functionally rich if there is no more than one syncretism per tense.

Somewhat more problematic might be the situation in old Church slavonic, where one finds two syncretisms within a single tense. In OCS both the imperfect and the aorist display, in addition to the syncretism just mentioned for Bulgarian, a syncretism between the 2 nd person plural and 3 rd person dual, as illustrated in (36) and (38).

(35) jadXaße Imperfect: 'eat' 2nd/3rd sg

(36) jadéasete Imperfect: 'eat' 2 nd pl or 3 rd dual

(37) jastb Aorist: 'eat' 2nd/3rd sg

(38) jaste Aorist: 'eat' 2 nd pl or 3 rd dual

It can be shown (cf. Lindseth and Franks 1994; Franks 1994) that the use of the same form for the 2 nd person plural and 3 d person dual does not count as a syncretism in the relevant sense. A syncretism reflects a single form that is non-distinct from more than one feature complex, i.e. it is a defective feature matrix. Verb forms that are lexically associated 
with such defective feature matrices can be substituted for multiple, fully specified AGR matrices at s-structure. A form, such as (35) jadęałe '(you-sg/(s)he) was eating', for instance, can be analyzed as having the pronominal features $[-1 s t,+s g]$, rendering it non-distinct from both 2 nd and $3 r d$ person singular agreement. However, when the features cut across both person and number, as in (36) jadeasete '(you$\mathrm{pl} /(\mathrm{s})$ he-dual) was eating', this is not an instance of feature neutralization, because it cannot be expressed using a single entry in the lexicon. The fact that this is technically not a syncretism provides a possible explanation for why identification of null subjects is not blocked in ocs.

Now compare the Upper Sorbian forms below with the ocs forms in $(35-38)$ :

(39) piješ Imperfect: 'drink' 2nd/3rd sg

(40) piještaj Imperfect: 'drink' 2nd/3rd dual

(41) wupi Aorist: 'drink' 2nd/3rd sg

(42) wupiłtaj Aorist: 'drink' 2nd/3rd dual

In contrast to ocs, Upper Sorbian exhibits two real syncretisms within a single tense, violating condition (31) for the identification by functional richness. Common slavic had distinct forms for the 2 nd and $3 \mathrm{rd}$ person dual. In (Upper) Sorbian there is no distinction between the 2 nd and 3 rd person dual (in addition to the inherited syncretism between the 2 nd and 3 rd person singular in the imperfect and aorist). The two 
different forms of the Common slavic 2 nd and 3 rd person dual have been reinterpreted as a gender distinction, at least as far as the literary language is concerned.

Table 3: The Dual in OCS and in Upper Sorbian OCS Upper Sorbian

$\begin{array}{lllc}\text { Dual Present } & \text { lot } & \text { nesevé } & \text { njesemoj } \\ & \text { 2nd neseta } & \text { njesetaj/njesetej } \\ & \text { 3rd nesete } & \text { njesetaj/njesetej }\end{array}$

In literary Upper Sorbian the - taj ending is used in reference to male persons, while -tej is used for all other genders. However, most Upper Sorbian dialects do not express this distinction and use only the ending -tej.

We have seen that an approach to identification in terms of Roberts's restrictions on the number of allowable syncretisms seems to provide an account for the lack of identification in Upper Sorbian. ${ }^{28}$ However, there is one major drawback to this sort of morphological explanation: This account makes the bizarre prediction that the loss of the dual in Upper Sorbian should reinstate the successful identification of null subjects in Upper Sorbian. The Sorbian verbal paradigm without the dual would be "functionally rich" in the

28 Roberts's account is intended to explain why French lost null subjects entirely. A strict interpretation of Roberts would thus predict that Sorbian has no null subjects at all, and could not account for the apparent optionality of subject pronouns. In this context see also 4.6.3. for a discussion of the general challenges the Sorbian situation provides for identification/licensing frameworks, and 4.6.4. for an alternative analysis. 
sense defined by Roberts and thus no violation of principle (31) would occur.

Ideally, we should compare data from old Sorbian before and after the merger of the 2 nd and $3 \mathrm{rd}$ person dual to see whether this change brought about a concomitant increase in the use of overt subject pronouns. Unfortunately, this is not possible, because the earliest Sorbian texts are relatively recent (16th century) and already show an extensive use of overt personal pronouns in subject position, which is similar to today's colloquial language. There might be yet another way to determine the validity of Roberts's syncretism account for Sorbian. Some dialects of Upper Sorbian have only infrequent use of the dual number. Fieldwork might be able to determine whether or not there are dialects which lost the dual completely, and whether or not such dialects really have the relevant null-subject characteristics which were found to be missing in the dialects which preserved the dual.

In this context, let us return to Russian. On the basis of the null-subject criteria I argued that Russian is not a canonical pro-drop language. An explanation for the lack of identification of referential null pronouns was given in terms of the lack of $A \mathrm{AR}_{\text {pers }}$ in the past tense. We might now try to see whether Roberts's theory can be applied to Russian as well. It turns out that "defects" in the past tense paradigm can once again be interpreted as the culprit for blocking identification. Russian past tense verbs are marked for gen- 
der in the singular, but this opposition is completely neutralized in the plural.

Table 4: Russian Past Tense

$\begin{array}{lll}\text { Sg. Masc. } & \text { byl } & \text { PI. byli } \\ \text { Fem. } & \text { byla } & \\ \text { Neuter bylo } & \end{array}$

Since the singular distinguishes masculine, feminine and neuter, there must be a double syncretism of gender features in the plural. Identification by functional richness thereby fails.

\subsubsection{A word order account}

While it is in principle possible to formulate an explanation for why Upper Sorbian is not a null-subject language in terms of a restriction on the number of syncretisms in the morphological marking. I also pointed out the counterintuitive predictions associated with this approach.

The non-pro-drop properties of Sorbian may also be attributable to some other aspect of its syntax. An inspection of Sorbian texts reveals a striking preponderance of verbfinal declarative sentences, in contrast to other slavic languages, such as Czech, for example. The sentences below are taken from Michalk (1962b) and are drawn from both literary and dialectal sources. ${ }^{29}$ Sentences (43) and (44) are examples 
of verb-final subordinate clauses; (45-49) illustrate the verb-final position in main clauses.

(43) nan sebi mysleše, zo so na druhi dzen father self thought that refl at other day 2 nasim susodom wrót with our neighbor will-return

'Father thought to himself that he would return with our neighbor on the next day'

(44) Marka so woprawdze wjeseli, zo jónu skoro zaso Marka refl really rejoices that once soon again do Lipska pojzdío to Leipzig will-drive

'Marka is really glad, that she will soon once again go to Leipzig'

(45) a hižo psaj kaz zlo njedobro płez and already dogs aw like evil not-good through répu na Jancowu Exrjertaj beets at Jancowa ranow 'and already the two dogs came running like the devil through the beets towards Jantowa'

(46) tutón jeho pak na pue $k$ sibjency dowjedé that $_{\max }$ him $_{\text {ex }}$ however at way to gallows will-lead 'but that one will lead him on the way to the gallows'

(47) ta husto po Marku na spewanje płifidfo that $_{\text {fom }}$ often for Marka at singing comes 'she often picks up Marka to go singing'

(48) moj 2 Marku najwajacy na polu stojimoj we $_{\text {dur }}$ with Mark most-often at field stand 'I and Marka stand the most on the field' 
(49) najradక̧o so ludío njedźelu wabžlokaja ${ }^{30}$ most-gladly refl people sunday get-drunk 'people prefer to get drunk on Sunday'

In other Slavic languages the sentence-final position may, of course, also be occupied by the finite verb, especialIy if the verb is the rheme, i.e. the element which provides the newest, most important part of information. In general, the final position in those languages seems to be reserved for the rheme. However, in the Sorbian examples above considerations of functional sentence perspective should not have contributed to the final position of the verbs. What is important for our discussion is that the umarked position for the finite verb in both the literary and colloquial language seems to be clause-final. Michalk (1962a; 1962b) provides some interesting figures. The ratio of verb-final versus verb-internal position came out to be $62 \%: 38 \%$. According to Michalk, in $55 \%$ of all analyzed sentences with the finite verb in final position the verb did not belong to the rheme. In $86 \%$ of all cases where the finite verb did not show up in final position, the verb was immediately followed by the rheme in final position. This indicates that the verb can be displaced from its unmarked final position in order to put the rheme there instead. The tendency to put the finite verb into final position, even if it is not the core of the new informa- 
tion, was found to be even stronger in the literary language than in colloquial speech.

As far as subordinate clauses are concerned, this structure is, of course, very reminiscent of German, where the finite verb must always be in final position. ${ }^{31}$ In Sorbian this verb-final tendency is true for both subordinate clauses and main clauses, though it is just a preference and not an ironclad rule. In German, the finite verb must be in the second position in main clauses. The Sorbian verb can occur in non-final position, especially when some element other than the verb is clearly the rheme.

Based on this discussion I propose that the underlying word order in Sorbian is sov. For German, sov order is often derived by analyzing AGRP (and VP) as right-headed, so that when $V$ raises to $A G R$ it will end up in clause-final position, as shown in the structure (50) below:

31 Even in subordinate clauses, Sorbian word order is not identical to that of German. In the perfect and past perfect, the auxiliary typically follows in second position right after the conjunction (in $87 \%$ of all cases according Michalk 1970: 23), while the 1-participle is in final position. Compare the Sorbian and German examples below.

(i) hdyz sym ja $z$ chorom w B. bylaz

(ii) wenn ich mit dem Chor in $B$. gewesen $b_{1} b_{1}$

'when I have been in $B$. with the choir' 
(50) AGRP

NP

$\begin{array}{llll} & & \text { AGR' } \\ & & & \\ & & & \\ & & & \\ N P & v G R & \\ 0 & & t_{i} & v_{i}\end{array}$

I propose that the right-headedness of AGRP also accounts for word order in Sorbian, the difference being that since AGR (unless it is a clitic) does not raise to $C$ in Upper Sorbian, conjugated verbs are $f$ inal in both main and embedded clauses.

In analytical tenses, such as the perfect and past perfect, the auxiliary is typically in second position, while the 1-participle occupies the final position. Consider the following examples, taken again from Michalk (1962b):

(51) ja sym nekotru zakrasnjenu myš popanyd $\mathbf{a}^{32}$ I $\operatorname{aux}_{1 s g}$ some nice mouse caught

'I caught some nice mice'

(52) mój nan bð tydzeń prjedy wotrołka my father aux 3 se uperf week ago farmhand naswar 11

scolded

'my father had scolded the farmhand a week ago'

(53) $\mathrm{mi}$ so zda, zo oym prawje wulku rybu popanyl

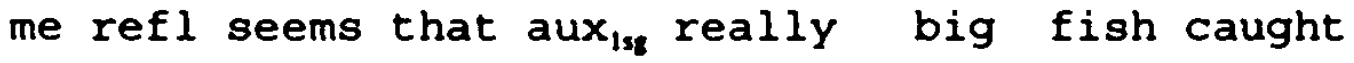

'it seems to me that I caught a really big fish'

This is very reminiscent of German matric clauses: Ich habe einige Mäuse gefangen.

'I've caught some mice' 
Referring back to the proposal in Chapter 3, I assume the existence of different $A G R$ projections ( $A G R_{\text {pers }}$ and $A G R_{\text {end }}$ ) in Slavic. The examples above seem to indicate that all functional projections of the verb except for CP are right-headed. This is illustrated in the structure in $(62):{ }^{33}$

(54) $\operatorname{spec}^{\mathrm{CP}} \quad-C^{\prime}$

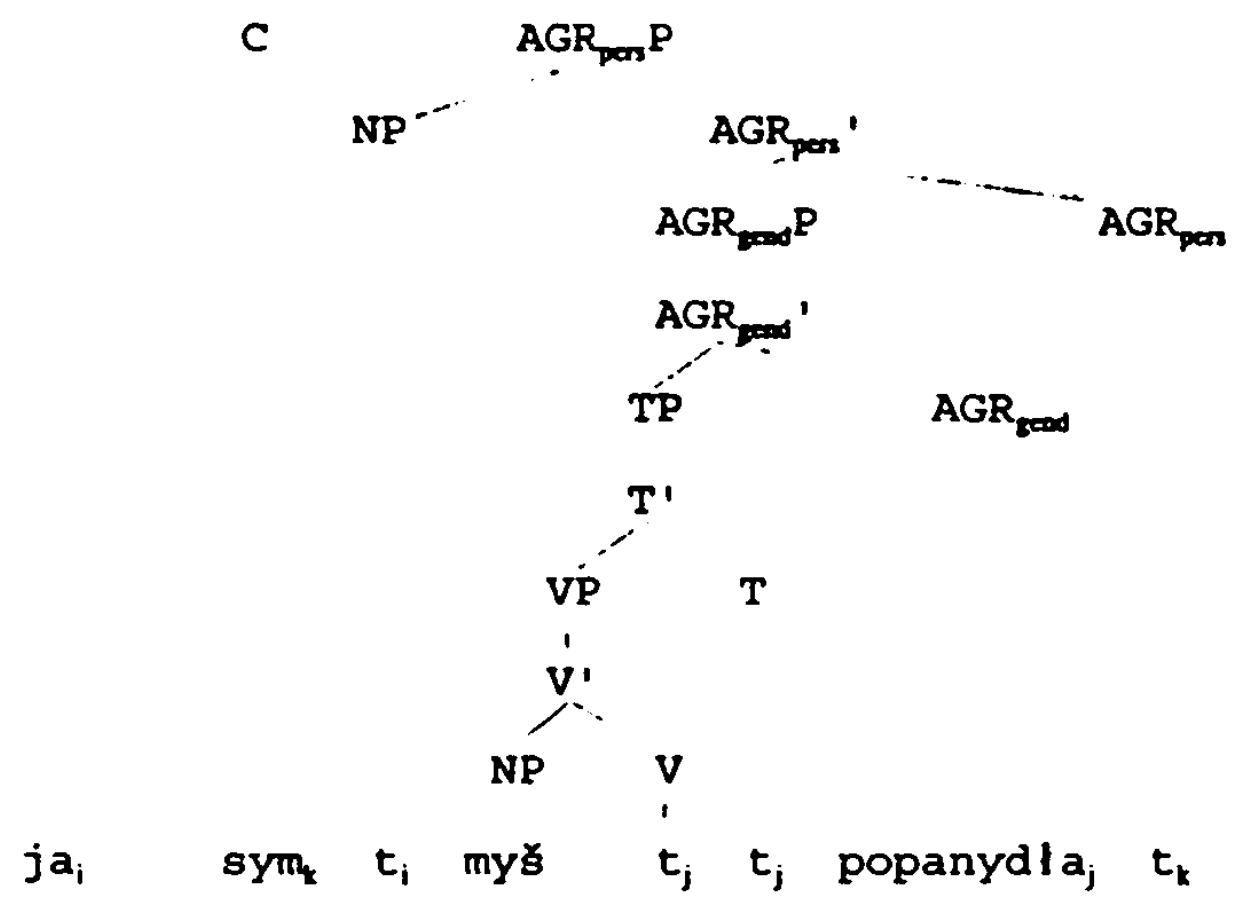

It is thus possible that the lack of identification of null subjects in Sorbian is somehow connected to the direction

33 If the auxiliary is negated, it loses its clitic status and is found most often in final position (cf. Jent 1959: 27-28), as illustrated in the example below. Presumably it then occupies the head position of $A_{G R}$ pers or NegP.

ja pak jeho widkal njejoym

I however him saw not-aux ${ }_{\text {iss }}$

'I, however, didn't see him' 
of branching of $A G R_{p e n}\left(A G R_{s}\right)$. I speculate that the problem in Upper Sorbian may have to do with the non-adjacency of the head of AGRP $\left(A G R_{\text {pers }} P\right)$, (which would be the $A G R$ carrying the pronominal features necessary for identification), and the specifier, (which would be the position for pro). This nonadjacency, which makes AGR, despite its richness, somehow not accessible to the null subject, is underlying in all sentences, and is also usually present at s-structure, unless a clitic is present as shown in structure $(54) .{ }^{34}$ It is possible that Sorbian developed its predilection for the final position of the finite verb under the influence of German subordinate clauses. However, Sorbian has generalized that structure in its own way, and the problem for the identification of referential subject pronouns can thus be found within the Sorbian syntax itself.

Just as with the syncretism approach to the issue of null subjects (or lack thereof) in Sorbian, there are also some potential problems for the word-order based account. The literary language is just as verb-final as the colloquial language, if not even more consistently so. However, we have also seen that in literary Sorbian, overt subjects are usually omitted. This situation raises the question of how these

34 Note that German, despite its uniform realization of a relatively rich $A_{G R}$, is also not a canonical nullsubject language. One might speculate that in German too. the fact that thematic null subjects cannot be identified has something to do with the non-adjacency of the head of AGRP and the specifier position (but cf. also fn. 14, Chapter 2). 
frequently occurring null subjects are identified in literary Sorbian if identification is blocked by non-adjacency of $A_{G R} R_{\text {pers }}$ and the subject in $\left[\mathrm{Spec}, \mathrm{AGR}_{\mathrm{pers}} \mathrm{P}\right]$. It is also the case that there are many instances of null subjects in colloquial Sorbian. If one denies the possibility of identification these should be treated as discourse-licensed ellipses. That would imply that null subjects in literary Sorbian and in colloquial Sorbian are instances of different phenomena, which does not seem very likely. Finally, as pointed out in Lindseth and Franks (1994), one obvious problem with implicating the direction of branching in blocking identification is that there are Sov null-subject languages, which raises the question of why adjacency should be a factor in Sorbian or German, but not in Turkish or Hindu.

\subsubsection{Challenges for the identification/licensing framework} The problems mentioned in the previous sections arise when we attempt to solve the issue of pro-drop in terms of a highly restricted framework of syntax, trying to account for linguistic phenomena in terms of setting binary parameters and formalizing precise conditions for the occurrence of certain elements. The paradox is that any non-linguist is able to see why it is possible to omit subject pronouns in both literary and colloquial Sorbian: They are redundant because the verbal endings carry overtly the information which is necessary to recover the pronominal content of the missing pronouns. 
In general, it seems that most versions of pro licensing/identification, such as Rizzi (1986), Jaeggli and Safir (1989), Rohrbacher (1995), Speas (1994), and also the ones discussed in the previous two sections (Roberts (1993) and the word-order account) will encounter two major challenges with respect to the Sorbian data. ${ }^{35}$ First, such an approach cannot account for the optionality of overt and null-pronominal subjects in Sorbian. Most versions of the licensing/identification framework predict that a language will either license/ identify null subjects or it will not. Second and related to the first problem, they cannot predict the difference in frequency of null or overt pronouns with different persons of the verb, especially if such a frequency difference cannot be attributed to functional compensation for missing morphological marking on the verb.

We have seen that literary Sorbian does comply with the "subject-pronoun-prohibition rule" given in puristic grammars ,

35 An analysis à la speas fails to account for the whole range of sorbian data, although at first glance it might appear to be wide enough to cover systems like Sorbian (though certainly not in a very interesting way). Speas considers "strong" agreement as a necessary, but not sufficient condition to treat agreement affixes as individual lexical items. Sorbian fulfills the conditions on "strong" agreement, and should thus have the option of having lexically listed affixes. Under Speas's analysis, Sorbian has chosen otherwise, by listing agreement affixes as part of the verbal paradigm. However, this should make the occurence of any null subjects a violation of the principle of economy, and we cannot account for the optional character of nuli subjects. Moreover, this type of analysis would also fail to give an explanation for why Sorbian is different, and instead blame it all on a "lexical idiosyncracy" of the sorbian agreement morphemes. 
especially with respect to 1 st and 2 nd person subject pronouns. However, nonemphatic 3 rd person pronouns do occur more frequently in literary Sorbian. ${ }^{36}$ The following are examples of non-emphatic pronoun subjects from the novel by Koch (1991) which was mentioned above for its zero subjects:

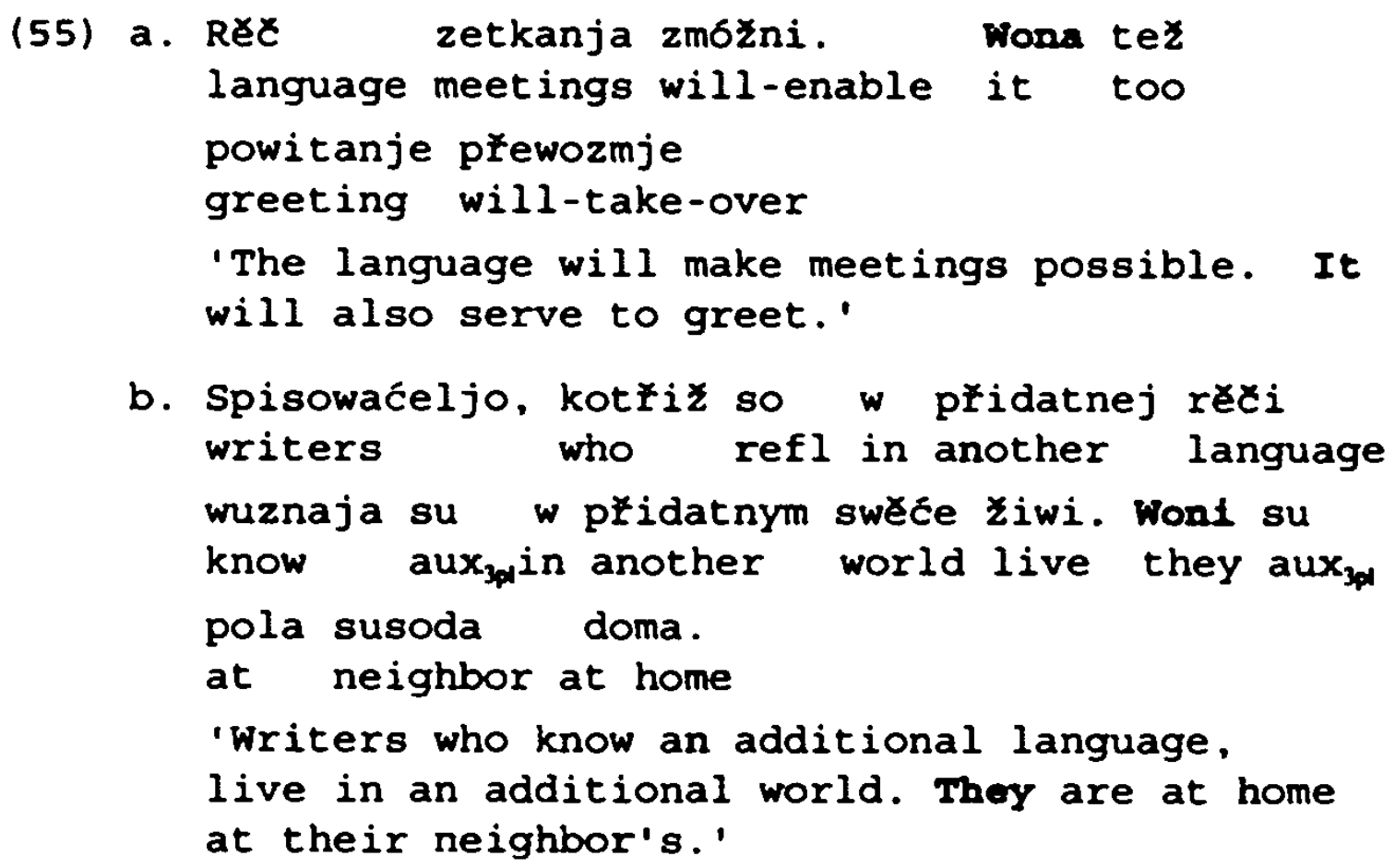

Also recall the literary example (21a) repeated here as (56), which shows that even in the literary language a personal pronoun may be coreferential with the matrix subject.

(56) Feliks njepytny, zo wón hižo hodzinu po mesše honja 'F. didn't realize, that he had already been running through town for an hour'

36 Steven Franks (personal communication) reports a similar phenomenon for Bulgarian. 
A particularly striking (and apropos) example is the following text found in the Sewc grammar (1974: 118). Bear in mind that this is the same grammar which states that there is only a very limited use of personal pronouns in Upper Sorbian. ${ }^{37}$

Personalne pronomeny wón, wona ... njepocahuja so ... jenoz na wosoby, ale tež na zwerjata a wecy. Wone maja přez to zdobom క̌̌rši woznam. Wosebitosć personalnych pronomenow 3. wos. zwuraznja so dale w tym, zo pocahuja so wone zwjetša na něsto, stoz je hizo $z$ konteksta znate. Wone wobhladuja so tohodla jako wosebita skupina pronomenow ...

'The personal pronouns won, wona ... ('he', 'she' ...) do not only refer to people, but also to animals and things. Therefore they have a broader meaning. The special character of the $3 \mathrm{rd}$ person pronouns finds further expression in the fact that they more often than not refer to something which is already known from the context. They are therefore considered a special group of pronouns...'

This skewing in person appears also to be reflected in colloguial speech. Even speakers who are influenced by the literary language and tend to omit the personal pronouns of the 1st and 2nd person will frequently use a 3 rd person pronoun. Consider the following examples:

(57) (ja) bydlu w Budyšinje

'I live in Bautzen'

(58) woni bydla w Budysinje

'they live in Bautzen'

37 To be fair I need to mention that Šewc (1984: 117) only refers to 1st and 2nd person pronouns in saying that their use is reserved to emphasize the subject. On the other hand, his comment about the restricted use of pronouns refers to all persons, and he does not imply anywhere that the pronouns of the 3 rd person are used more frequently. 
(59) wón bydli w Budysinje 'he lives in Bautzen'

In (57), about 708 of my informants ${ }^{38}$ used overt ja, while 1008 used woni in (58) and won in (59). This was true in the perfect tense as well:

(60) (ja) sym sej toßu kupil I aux $_{1 s g}$ refl bag bought max $_{\text {m }}$

'I have bought myself a bag'

(61) wón je sej tołu kupil he aux $_{34}$ refl bag bought

'he has bought himself a bag'

Even speakers who omit the personal pronoun in $(60)$ use won in (61). In fact, most native speakers felt that the personal pronoun of the $3 \mathrm{rd}$ person in sentence-initial position was obligatory. When shown literary examples with 3 rd person null subjects in initial position they felt that these were "unusual" and "misleading". 39

38 I interviewed approximately 20 native speakers of various ages and educational backgrounds.

39 Virtually all informants also used overt $3 \mathrm{rd}$ person pronouns in other positions in the sentence, as shown in (i) and (ii). However, most of them also seemed somewhat more willing to accept constructed examples without the pronoun.

(i) je sej wón tu tosu kupil aux $_{3 s g}$ refl he this bag bought 'did he buy the bag yesterday'

(i') ? je sej tu tosu kupil

(ii) wCera je sej wón tu tosu kupil 'yesterday he bought the bag'

(ii)? wčra je sej tu tosu kupil 
The question arises whether there might be a connection between this difference in the frequency of overt pronouns and the verbal morphology of sorbian. It is true that in the 3 rd person present tense, as well as in the imperfect and past, there is no marker on the verb which specifies the gender so that the use of a personal pronoun might be blamed on the otherwise threatening ambiguity. In other words, kupuje ('buys') can refer both to won and wona, just as the plural kupuja can refer to wone or woni. However, if this were the reason, then we could expect frequent omission of the subject pronoun in the $3 \mathrm{rd}$ person singular in the perfect tense, where the gender is unambiguously expressed on the 1-participle. This expectation is not borne out, as the comparison of examples (59) and (60) shows. Moreover, in other Slavic languages which are pro-drop languages, such as Czech and Polish, the same situation obtains as far as the non-expression of gender in the present tense of the 3rd person is concerned. Nevertheless, in those languages null 3 rd person pronominals are totally normal in unmarked contexts. In this connection I argued in 3.2. that only $A G R_{\text {pers }}$ and not $A G R_{\text {gend }}$, seems to be relevant for the identification of null subjects.

\subsubsection{The competition model and the loss of pro-drop}

Most versions of the licensing/identification framework follow the traditional wisdom that there is a direct link between the inflectional richness of a language and the availability of 
null pronouns. While it seems plausible that a language would lose the ability to have null subjects if it loses the morphological marking of agreement features on the verb, there are languages, such as Icelandic, German, French, Rhaeto-Romance of Switzerland and some northern Italian dialects (cf. Orešnik (1986: 266)) which resist such a purely functional view of the loss of null pronouns. ${ }^{40}$ Orešnik points out that these languages developed obligatory subject pronouns when they possessed (and some still possess) full and unambiguous morphological markings on the verb.

Sprouse and vance (1995) provide an interesting alternative to attempts made strictly within the principles and parameters framework to account for the (gradual) loss of null pronouns in languages which were once pro-drop languages. Based on data from the history of French and the Surselvan dialect of Rhaeto-Romance they argue against a purely functional view of the loss of pro-drop in terms of a change (decline) of morphological marking on the verb. Instead, following work by kroch (1989), they show how a competition model of

40 Oresnik (1986) points out that in Old High German there was a person skewing with respect to the use of nullsubject pronouns. The pronominal subjects were more frequent in the first and second persons than in the third. He associates the origin of unemphatic pronoun subjects with a "strengthening", which started first in the so-called "strong" positions. The third person, as the least marked person is also the least likely to become strengthened. Oresnik thus proposes that the same state of affairs with respect to the differences among the verbal persons should obtain in all languages. It seems that Sorbian is a counterexample to this hypothesis, because we find a clearly higher frequency of $3 \mathrm{rd}$ person pronouns in that language. 
language change can account for a syntactic change over time, one example of this being the gradual loss of pro-drop properties in a language. I will not present the details of Sprouse and Vance's analysis here, but the following is a short summary of their hypothesis. Two forms of a language are said to be in "competition" if they make exactly the same contribution to the semantic meaning. Once a language has two competing forms, speakers attempt to match the relative frequency of these forms. Over time the relative rates for two competing forms will shift in favor of the form which is parsed more reliably, whereby "parsing" simply means grammatically based understanding of an utterance. Once this process is set in motion it will finally lead to the predominance of one form and the loss of the other.

Applying this idea to the issue of null subjects, it can be assumed that sentences with overt pronouns would be parsed more successfully than sentences with null pronouns. However, in order for a drift towards a high frequency of overt pronouns to take place, null and overt pronouns in that particular language must have the same referential properties. Otherwise, they will not be in competition and the pro-drop character of the language will remain stable. Consider the following Czech sentences:
(62) a. ja mluvím resky
'I speak Czech'
b. e mluvím Cesky.
'I speak Czech' 
The overt pronoun and the zero form in the two sentences above do not represent competing forms. Ja in Czech is a tonic pronoun and is used emphatically. The zero pronoun, on the other hand, is an atonic pronoun. The different referential properties of overt and zero pronouns in a null-subject language such as Czech can also be illustrated in the following type of construction: ${ }^{41}$

(63) a. Petri mysli, Ze *on $/$ pro, má mnoho penéz 'Peter thinks that he has a lot of money'

As we have already seen in the course of the application of the null-subject criteria to Czech, the overt pronoun cannot be bound by the higher subject in the matrix clause, even though this is possible for the zero pronoun. In other words, while pro seems to be subject to condition B, the overt pronoun in a null-subject language seems to obey binding condition $C$ (which boils down to the same relevant difference in the referential properties between overt and null pronouns previously pointed out by Jaeggli (1986) and Montalbelli (1984)).

In Sorbian, on the other hand, the situation is actually quite different. We demonstrated above that overt pronouns are not restricted to emphatic contexts and that embedded

4) Sprouse and Vance propose the same type of construction as a reliable criterion to identify competing forms. 
overt pronouns can be coreferential with a matrix subject. Example (21f), repeated here as (64), illustrates this.

(64) Jana je prajila, zo chce wona,/e, rady kupac hić 'Jana, said that she, would like to go swimming'

Thus there is a true competition in the relevant sense between overt and zero pronouns. If we define a null-subject language in terms of the three diagnostics in (20), a language ceases to be pro-drop as soon as there are atonic overt pronouns. The advantage of the competition model is that it allows for a gradual change in the frequency of null subjects over time, including a period of optional pro-drop, without being pressed to look for a change in a parameter setting. The competition model is not concerned with the formulation of precise licensing and identification conditions, though it does not explicitly deny their existence. For this sort of approach it is totally expected that there are languages in transition, during which there are both zero and overt subjects. For a licensing/identification approach there is no in-between: either null subjects are licensed or they are not. Sprouse and Vance point out that their theory is not incompatible with a parameter-setting approach such as the one presented by Roberts (1993). Their competition model is best equipped to account for a gradual loss of pro-drop properties without concomitant change in the explicitness of verbal morphology. By itself though, this model fails to explain any 
sort of sudden change, such as the disappearance of post-verbal pro in French during the 17th century discussed in section 4.5.1.

Applied to Sorbian, the competition model of language change might give the following account for the loss of canonical null-subject properties. At an early stage atonic pronouns entered the Upper Sorbian language. The source for this is not clear, but German influence could certainly have played a major role as the region became bilingual.42

Another possible origin of atonic personal pronouns might be found in the relative order of the auxiliary and the participle in the perfect and past perfect. In contrast to czech or Polish, in Sorbian the auxiliary has to precede the 1-participle in neutral style. In Czech, the order viderl jsem

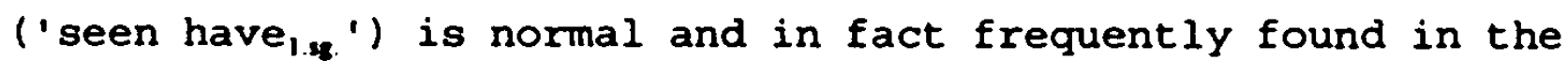
initial position of a sentence. The czech auxiliaries are second-position clitics, and the form jsem in videl jsem is clitized to the preceding participle. Similarly, Sorbian auxiliaries are enclitics. ${ }^{43}$ However, for Sorbian the word order option "participle - auxiliary" is not available. "the auxiliary has to precede the participle, so that ja sym widzat,

42 Sprouse and Vance do not identify the origin of atonic pronouns in Romance languages, but they doubt that a neighboring language had any role in that process.

43 According to Michalk (1965), Sorbian clitics prefer the "Wackernagel" position, although post-verbal position can exist if the verb occupies the second position in the clause. (cf. En. 33). 
with the overt personal pronoun preceding the clitic, is the equivalent to the previously mentioned Czech example videl jsem. A Czech speaker would not use the same order of elements as Sorbian, unless the subject is supposed to be especially emphasized.

As discussed in section 4.4 , it can be assumed that by the 18th century overt pronouns had established their predominance over the null variant, both in spoken and written sorbian. However, in the second half of the 19th century the frequency of null pronouns suddenly increased again, mainl? in the written language, but presumably also in spoken Sorb:an. Null pronouns were artificially (and forcefully) favorec by prescriptive grammars trying to root out the German influence in the Sorbian language and recreate Sorbian as a real ntllsubject language based on the czech model. Such a shift in the literary language may have made the pro-drop phenomenon socially significant by introducing what we might call a "prestige factor" which artificially influenced the relative frequency of overt and null pronouns." The better educated and well-read members of the population began to try to imitate the literary language by reducing the frequency of overt pronouns in their speech. This tradition is still alive to-

4 Sprouse and Vance mention that they abstract away from prestige factors in the history of French null subjects. In the 17th century French grammarians discouraged the onission of pronouns, which might have caused an artificial stift in the relative frequency of overt and null pronouns in favor of the latter. 
day, as shown earlier in this chapter. Uneducated, simple peasant speech in literary work is imitated in part by the obvious use of overt pronouns. Moreover, all Sorbian children are taught in school to avoid the (over) use of overt pronouns. This all may explain why Sorbian today still has a competition between overt and null pronouns. Moreover, it can also account for the direction of change lovert pronouns $\rightarrow$ null pronouns), which apparently goes in the opposite direction from what the competition model predicts and is particularly striking in literary Sorbian, where null subjects became dominant. overt pronouns do predominate in colloquial speech; however, the influence and frequency of the zero variant is great enough to keep the competition going.

Under such an account Sorbian should be analyzed as a truly optional null-subject language. In most environments null and overt pronouns seem to occur basically in free variation, with preference given to the overt variant. We might even try to reconcile a competition model approach to null subjects with a licensing/identification approach. Sprouse and Vance's model is meant to account for the change of prodrop properties over time. They do not deal with the problem of what allows or prevents null subjects originally, i.e. they are not concerned with licensing and identification conditions. If we assume that there is some syntactic mechanism in the grammar of a native speaker which ensures the recoverability of null subjects, the question arises of whether or not 
this mechanism remains intact in the process of a gradual loss of pro-drop. Put differently, we can ask the question of whether or not Sorbian is really a non-pro-drop language, in the sense that identification of referential null subjects is blocked. Perhaps the licensing/identification mechanisms have not been lost in Sorbian, so that there has not been a parametric shift as such. It is thus possible that the occurrence of null subjects in Sorbian (both literary and colloquial) is indeed a case of genuine pro-drop and thus does not have to be analyzed as discourse licensed ellipsis.

This approach would eliminate the problems raised at the end of section 4.6 .2 . specifically the question of how to account for the identification of null subjects in literary Sorbian. It also explains why purism could be so successful in (re) introducing null subjects into the literary language: the syntactic mechanism of identifying null subjects was (and is) intact in the grammar of native speakers. The null-subject diagnostics, which are based on the clear division of labor between null and overt pronouns found in canonical nullsubject languages, such as Italian and Spanish, fail due to the atonic character of Sorbian personal pronouns. Interestingly, this lack of a division of labor is true not only for the colloquial language, but also for the null-subject literary language, as shown in example (56) above. 


\subsection{Lower Sorbian}

The main focus of this chapter has been Upper Sorbian. Although Lower Sorbian lays claim to a separate literary language, it is clear that the two languages are very closely related. It is not my intention to support one side or the other in the ongoing debate about whether there are really two separate Sorbian languages, but it is still worth looking at Lower Sorbian in the context of null-subject phenomena.

Lower Sorbian developed the same ambiguity between the 2nd and $3 \mathrm{rd}$ person dual as Upper Sorbian. In the aorist and imperfect paradigms this leads to a double syncretism, since it also preserved the syncretism between the 2 nd and 3 rd person singular from Common Slavic. Compare the Lower Sorbian verbal paradigm below with that of Upper Sorbian in Table 1.

Table 5: Verbal Paradigm of Lower Sorbian zetas 'to work'

Present/Future Imperfect

Aorist

Sg. 1. zélam

2. ¿etas

3. Eéla

Dual 1. Eelamej

2. ¿elatej

3. Eelatej

PI 1. Eelamy

2. zelaso

3. Eelaju zelach

żlabo

¿ชి ă̌o

zel achmej

zxlartej

żlartej

zel achmy

¿Xl aśo

zelachu naźelach

nažla a

nažla

nazelachmy

nażlartef

nażlartej

naze lachmy

nazèlašco

naze lachu

According to standard Lower Sorbian grammars, personal pronouns in subject position are not obligatory and usually 
omitted. Starosta (1991:40) gives a description reminiscent of a null subject language. According to him, personal pronouns are only used in emphatic contexts or in order to avoid misunderstandings. Janas (1984: 171) is more noncommittal, describing their use as optional. In general, the use of overt pronouns in Lower Sorbian seems to be comparable to Upper Sorbian. The following examples are taken from Nowak's (1988) Gutes Niedersorbisch, which is a guide to "good" usage of the Lower Sorbian language.

(65) my stawamy akle ze slyńcom

we get-up only with sun

'we only get up with the sun'

(66) ze switanim jo won se wuporal

with sunrise aux ${ }_{3 g}$ he refl left

'with sunrise he set off'

(67) ga sy ty cora wusnul when aux $_{2 s}$ you yesterday fell-asleep

'when did you fall asleep yesterday'

(68) ja som pol nocy wocuseta lazala

I aux $_{\text {lse }}$ half night awake lay

'I lay awake half the night'

(69) my wjele nowego njezgonijomy

we much new not-hear

'we don't hear much new'

Note that in all these examples there would not have been any risk of ambiguity had the pronoun not been used. Neither are these sentences examples for overt pronoun use in emphatic or 
contractive contexts. ${ }^{4}$ Thus, Lower Sorbian is not a canonical null-subject language in the sense defined in previous chapters. The application of the other two null-subject criteria leads to the same conclusion. Overt Lower Sorbian woni ('they') can have arbitrary reading, thus contradicting diagnostic (20c). Similarly, an overt pronoun may have a bound variable reading, causing diagnostic (20b) to fail. This is illustrated in the examples below.

t6 Word order in Lower Sorbian has not been studied in as much detail as in Upper Sorbian. In principle the word order pattern seems to conform more or less with that of Upper Sorbian. Waurick (1968: 126) writes:

Wie im Obersorbischen herrscht auch im Nieder-sorbischen der Grundsatz, daß das nichtzusammengesetzte verbale Prädikat (verbum finitum) in der Regel am Satzende steht. Jedoch scheint diese Regel etwas großzügiger angewendet zu werden als im obersorbischen, denn verhältnismäßig hãufig tritt Zweit- oder Mittelstellung des nichtzusammengesetzten verbalen Prádikats auf. Anhnlich wie im Obersorbischen stehen bei einem zusammengesetzten verbalen Prädikat die finite Form des Hilfverbs gewöhnlich in Zweit-oder Mittelstellung und das 1 Partizip bzw. der Infinitiv am Ende des Satzes. Jedoch gibt es auch hier wahrscheinlich zahlreichere Ausnahmen als im Obersorbischen.

'As in Upper Sorbian, in Lower Sorbian there is a principle according to which the non-compound verbal predicate (finite verb) usually is in final position. However, this rule seems to be applied less strictly than in Upper Sorbian, because relatively often the non-compound verbal predicate occurs in second or middle position. As in Upper Sorbian, the finite form of the auxiliary in compound verbal predicates is usually in second or middle position, and the l-participle or infinitive at the end of the sentence. However, there are probably again more exceptions than in Upper Sorbian.' 
(70) a. w Londonje woni zasej stajaskuju in London they again strike

'in London they are again on strike'

b. we Lužycy woni maja rêdne stare nalogi

in Lusatia they have nice old customs

'in Lusatia they have nice old customs'

(71) a. kuždy nan se mysli, az won ma mudrego syna every father refl. thinks that he has smart son

'every father thinks that he has smart son'

b. kuždy płosaś se naźeja, až se won skoro every beggar refl hope that refl he soon rozbogasijo

becomes-rich

'every beggar hopes that he will soon become rich'

c. Frido we, az won njebuzo ains krydnus

Frido knows that he not-will A receive

'Frido knows that he won't get an $A$ '

As above with Upper Sorbian, it should be emphasized that there are also many instances of null-subject pronouns in Lower Sorbian, so that the overt and null variants seem to be in free variation. Below are some examples with the null variant, taken from Nowak's (1988) book.

(72) som jogo poznl wot jog nejlepšego boka aux $_{\text {ist }}$ him got-to-know from his best side

'I met him from his best side'

(73) cas zywjenja njejsom jogo poznal time life sen $_{\text {not-aux }}$ iss him met

'I have never met him in my entire life'

(74) na dobru gluku smy do kjarcmy zajšli

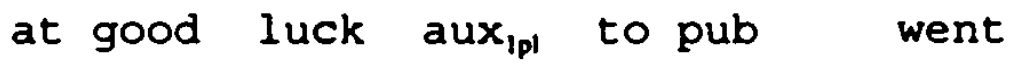
'we went to the pub on the off-chance' 
The use of overt pronouns is widespread in the earliest texts, such as the Lower Sorbian Bible translation from 1548 by Miklawus Jakubica. The translation of the New Testament by Jan Bogumil Fabricius in 1709 shows a very frequent use of overt personal pronouns. A direct comparison of one passage (Luke 10:31-35) reveals six overt pronouns in the Jakubica translation and nine overt pronouns, (including one overt expletivel, in the Fabricius translation. The Fabricius translation is cited below.

(75) Luke 10:31-35; Fabricius 1709

31. Wono pak pšifoźecy se stanu, az jaden mjeř̆nikna tej samej droze doloj zešo, a gaž jogo wupyta, ఓešo won mimo.

32. A teje rownosći tez lewita, gaz won na to mésto

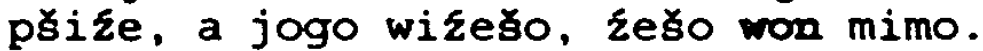

33. Jaden Samariski pak ducy na tej droze, p̌̌ize tam, a gaz won jog wizešo, bu jomu jogo luto.

34. A płistupjecy $k$ njomu hobalowašo mon jogo rany, a lejaso nuţ wolej a wino a sajzi jogo na swojo zwêrje, wję̌ě̌ jogo do gospody a zažarbowašo jogo.

35. A na drugi zeń dalej ducy wujmje won, a da jej tomu gospodarjoju, a zaకło k njomu: "Zazarbuj jogo, a buzos li njeco wjecej nalozys, cu ja tebe jo zaplasis, gaz ja pšidu".

Similarly, in Matthew 2:2-18, i.e. the same passage we used before for comparison between the different versions of Upper Sorbian Bibles, ${ }^{77}$ there are nine overt, non-emphatic pronominal subjects in the Jakubica and ten in the Fabricius version.

The use of overt pronouns is also evident in the everyday language of the 19 th century, as illustrated in the fol- 
lowing excerpts taken from Nepila's "Glodne leto". Nepila had very little formal training in writing and his autobiographical stories are said to closely reflect his native dialect of Lower Sorbian. Because of this, he is considered the first ludowy spisowacel ('writer of the people').48

... ja cu Wam tež jenu nowu powjesé prjodk Einjesć wót togo drogego letta tedym hako ja som maly byl a kajku ja jedz jedl som tedym we drogem a glodnem leče...

' I want to give you a new account of that year, back then when I was little, and what kind of food $I$ ate during that year of increased prices and starvation ...'

... da wóni su tež wopytowali wot šogo jð̌st, ale wóni su jare malo zjedli; woni su jesé wopytowali. ale wóni njejsu mógli teje jedsi jesć. Wóni wopytowali tez derje su, ale wóni su sycko roztylja rozchytali ...

'and they too tried to eat from everything, but they ate very little; they tried to eat, but they couldn't eat that food. They had a taste of it, but they threw everything around ...'

The serbske narodne wozrodzenje did not reach Lower Lusatia until the end of the 19th century. Even then, the striving for purism in the literary language was not quite as strong as in Upper Sorbian. The version of the Lower Sorbian New Testament published in 1895 in Halle was still Fabricius's (1709) translation. In Upper Sorbian, on the other hand, a new Bible translation by Luscanski and Hornik was published which was "cleansed" of virtually all subject pronouns which 
were so abundant in Swetlik (1690). 99 The Upper Sorbian example below is the same passage as the Lower Sorbian in example (75). There is only one overt personal pronoun in (76), compared to nine in $(75)$. so

(76) Luke 10:31-5; Lustanski and Hornik 1896

31. Sta pak so, zo mešnik po tom samym pucu dž̌̉e, a wuhladawši jeho, płeńdźe nimo.

32. Tak tez lewita, jako tam porno płińdze a jeho wuhlada, płendze nimo.

33. Jedyn Samaritan pak tam pucujo płińdze porno njemu, a wuhladawši jeho bu $z$ milosću hnuty.

34. A płistupiw̧i, zawjaza jeho rany, wolij a wino na nje linywsi, a sad乏i jeho na swoje skoço, dowjedze jeho do hospody, a zastra jeho.

35. A nazajtra wućahnywši dwaj dそesatnikaj da jej hospodarjej a praji: Staraj so za njeho, a stozkuli wjacy wulozis, ja, hdyz so wrócu, zaplacu tebi.

In summation, it appears that Lower Sorbian behaves more or less like Upper Sorbian with respect to the use of overt and null-subject pronouns.

\subsection{Sumary}

In this chapter I discussed the status of Upper Sorbian with respect to null-subject properties. Most grammarians describe Upper Sorbian as a canonical null-subject language, and the literary language in general avoids overt subject pronouns

$$
\text { Also compare section } 4.4 \text {. }
$$

so The personal pronoun in Luke 10:35 of the Lustanski and Hornik version is also present in the Latin Vulgate:

Et altera dir protulit duos denarios, et debit stabulario, et ait: Curam illius habe: et quodcumque supererogavis, ego cum rediero reddam tibi. 
(with the possible exception of 3 rd person pronouns). However, the situation is quite different in the spoken language. There, nonemphatic overt pronouns occur very frequently. I argued that the gap between literary and colloquial languages is the result of a strong movement for language purism which started in the second half of the 19 th century and strove to eliminate elements of German origin from the Sorbian literary language. An application of the three null-subject diagnostics to Upper Sorbian revealed that Upper Sorbian does not show the division of labor typical for a real null-subject language. I introduced three potential accounts of why Sorbian might be different from other west slavic languages with respect to its null-subject properties.

Two of the accounts were formulated within the licensing and identification framework. One possible solution to the question of what might be blocking the identification of referential pronouns was explained in terms of Sorbian crossing the threshold of allowable syncretisms required for functional richness of a verbal paradigm. The other possible account for the blockage of identification was derived from the peculiar Sov word order of Sorbian. Sorbian is underlyingly (and in most cases also at $\mathrm{S}$-structure) V-final. I speculated that the problem for identification may have something to do with the non-adjacency of $A G R$ and [Spec,AGRP].

The third proposal was based on an application of the competition model of language change to the issue of the grad- 
ual loss of pro-drop, as proposed by Sprouse and Vance (1995). According to this analysis, a null-subject language will start moving towards the complete loss of pro-drop as soon as atonic overt pronouns enter into competition with null pronouns. Atonic pronouns in Sorbian may have come about under German influence and/or as a result of the relative order of the participle and its auxiliary in the perfect and past perfect tenses.

All three accounts were able to explain why Sorbian is not a null-subject language in the strict sense (despite the fact that they had difficulties in accounting for certain data and/or made counterintuitive predictions). I argued that any strict application of the licensing/identification framework encounters problems in accounting for the optionality of Sorbian null/overt subjects. Thus, only the competition model analysis seemed flexible enough to make allowances for the specific character of Sorbian as an optional null-subject language, unless we want to assume that the presence of referential, atonic pronouns and the availability of an identification mechanism are not mutually incompatible. 


\section{THE STATUS OF OVBRT EXPLETIVES IN CZECH AND SORBIAN}

\subsection{Licensing/identification and the typology of languages}

In the previous chapters we were mainly concerned with the occurrence or lack of overt referential subject pronouns. However, the lack of overt referential pronouns in a language does not necessarily mean that the language allows no null subjects at all. In the review of the development of the prodrop parameter in Chapter 2 we saw that the existence of mixed languages (which have null non-referential (expletive) subjects but require overt thematic subjects) has suggested that the null-subject parameter cannot be monolithic as originally assumed.' As we have seen in Chapter 2, one standard approach to the problem of mixed languages is to capitalize on the distinction between licensing and identification conditions on null subjects. The licensing conditions specify the environment in which null subjects are allowed to occur. All null subjects, independent of their thematic status, must be formally licensed. However, only referential null subjects re-

1 Within government binding theory, expletive subjects are noun phrases in subject position which are not assigned a thematic role (such as agent. patient etc.). They are thus different from referential pronouns on the semantic level. There are also a number of syntactic differences. For example, in contrast to referential pronouns expletives cannot be questioned (except in tag questions) and cannot be coordinated with another NP. This is illustrated in the examples below:

(i) It is cold. What is cold? (it $=$ the beer) It is raining. *What is raining?

(ii) It and the coffee are cold. (it = the meal) *It and the coffee are cold. (with it = expletive) 
quire additional identification to ensure unambiguous recoverability of their pronominal content. Null expletives, on the other hand, merely need to be licensed. In a mixed language pro is formally licensed to occur in a certain position but is not identified. It follows that in such a language pro is restricted to expletives, which, due to their non-referential status, do not need to be identified. This type of system predicts the three different language types in Table 1.

Table 1: Possible language types (I)

i. canonical pro-drop languages

ii. mixed type: overt referential pronouns; null expletives

iii. canonical non-pro-drop languages

The essence of the licensing/identification dichotomy is that it is much easier for expletives than for referential pronouns to be null, since their pronominal content does not need to be identified. Identification is more "difficult" than licensing and can perhaps be understood as "more complete" licensing. ${ }^{2}$

The licensing/identification framework thus predicts that a language type with null referential and obligatorily overt expletive pronouns cannot exist. Hyams (1986: 71-74) points 
out that this prediction follows from Chomsky's avoid pronoun principle (1981: 65): ${ }^{3}$
(1) Avoid Pronoun Principle
Avoid lexical pronominal if a null pronominal is possible.

A language which allows null-referential subjects must be able to license null subjects in general. If pro is licensed, then a language will have null expletives. Indeed, Hyams extended this prediction to state that not only will expletives in such a language be allowed to be zero, they must be zero. In other words, languages which license phonologically null subjects will not contain lexical expletives at all. Note that even in a canonical null-subject language the subject pronoun is sometimes lexicalized. However, its use is reserved for special functional purposes, such as emphasis, contrast or change of discourse topic, and also avoidance of ambiguity, and thus is not a violation of the avoid pronoun principle. In certain contexts the overt variant cannot be "avoided", because it carries some additional meaning which the zero variant is lacking. The use of overt subject pronouns in a canonical null-subject language is thus determined by functional considerations. Expletive pronouns, on the other hand, are by definition void of semantic content, and it is a standard assumpjeopardize the general validity of Chomsky's principle. 
tion that they cannot be used for functional purposes. Thus, there should never be a reason to use an overt expletive subject in a null-subject language. Based on this idea, language acquisition theorists such as Hyams (1987: 74) have argued that the existence of overt expletives in a language serves as an unambiguous signal to the language learner that the language does not allow empty subjects of any kind. According to Hyams, the presence of overt expletives in a language is a "trigger" which induces the restructuring of the original parameter setting [+pro-drop] which is supposed to be the unmarked value of the null-subject parameter of UG.

Franks (1990) provides an interesting alternative approach to null subjects which places emphasis on different case assignment properties. He proposes two (more or less independent) parameters:

(2) Nominative Case features must be realized.

(3) Nominative Case assignment cannot take place at LF.

Descriptively, Franks calls (2) the overt expletive subject parameter [OESP], while (3) is the overt subject parameter [OSP]. In contrast to the previous system, these parameters do predict four different language types: 
Table 2: Possible Language Types (II)

i. [-OSP, -OESP]

optionally overt thematic subjects, obligatorily zero expletives

ii. [+OSP, -OESP]

obligatorily overt thematic subjects. obligatorily zero expletives

iii. [+OSP, +OESP]

obligatorily overt thematic subjects, obligatorily overt expletives

iv. [-OSP, +OESP]

optionally overt thematic subjects, optionally overt expletives

This notation is somewhat misleading, since [+OSP] means obligatorily overt thematic subject, but [+OESP] can mean obligatorily overt or optionally overt expletive subjects. depending on the setting for the [OSP] parameter. Similarly, [-OSP] means optionally overt thematic subjects, while [-OESP] means obligatorily zero expletives. The combination [+OESP] [-OSP] is thus not an instantiation of the fourth "forbidden" type under the licensing/identification approach. Instead, it means that while nominative case must be discharged to subject position there is the option to assign nominative at LF rather than at $s$-structure. These asymmetries between [OESP] and [OSP] are caused by the interaction of both nominative case parameters in (2) and (3) with the so-called case filter, according to which an NP must have case in order to be

4 Forbidden type: null referential subjects, obligatorily overt expletives. 
visible. Specifically, as mentioned by Franks (1990), there are two sides to this requirement: all overt NPs must be visible at PF; only theta-marked NPs must be visible at LF.

The main focus of this chapter is to discuss how Czech and Sorbian data are compatible or incompatible with the licensing/identification framework. Therefore, I will not follow this interesting line of argument any further here and will come back to Franks's (1990) proposal only as an aside. Below I will show how overt non-referential subject pronouns in spoken Czech, although in contradiction with Hyams's prediction about the total lack of expletives in any null-subject language, can be predicted by the licensing/ identification system without a violation of Chomsky's avoid pronoun principle. This is followed by a discussion of Upper Sorbian expletive-like pronouns. Because of the distributional restrictions on the occurrence of such pronouns I will argue that they do not cause any problems for the licensing/identification approach either.

\subsection{Spoken Czechs}

The standard, written language (spisouna đełtina), was codified at the beginning of the 19 th century by Josef Dobrovsky. Spisovna Ceština is based on 16th-century Czech, under the assumption that the German/Habsburg repression after 1618 had corrupted "pure" Czech. This romantic view of historic Czech

S The hypotheses and data in section 5.2. and 5.3. have, in part, been previously presented in Lindseth and Franks (1994) and Lindseth (1994). 
ignored several changes which had been developing in the Czech language since the 16 th century. The written language was in many respects already archaic at the point in time when it was recreated. It is, as the name spisovna indicates, a written and not a spoken language. The spoken language developed in a natural way without the artificial intervention of philologists. Thus there is a historic and linguistic gap between literary (written) Czech and spoken Czech. It is important to understand that the difference between the two cannot be compared to the difference between the written and spoken variants of other languages. As Townsend (1990) points out, all languages have layers of slang, dialect words, jargon. In Czech too, these layers are incorporated in the spoken language, and various emotive and subjective factors are relevant. However, there are large numbers of neutral pronunciations, morphological forms, syntactic constructions and words used by educated speakers in everyday conversation which differ from those prescribed by the literary language.

The term "spoken Czech" is somewhat problematical. It is sometimes used to refer to Common Czech (obecná Zeština), which is an interdialect spoken in Bohemia and Southwestern Moravia, or it can refer to Commonly Spoken Czech (bežne mluvená Ceština), sometimes also referred to as Colloquial Czech. Several linguists (Hammer 1985, Short 1993, Townsend 1990) see the literary language (spisovná testina) and Common Czech (obecná Cestina) as the two basic codes, while Commonly Spoken 
Czech (bežne mluvená Łestina) is somewhat of a transitional stratum. Short describes it as a "channel" by which "upwardly mobile features" of Common Czech can enter the standard language. Hammer (1985) describes it as a blend of literary and Common Czech, whereby Common Czech is the foundation, and speakers switch to the literary forms for functional purposes of emphasis, irony, intimacy, etc.

The following discussion is not focused on the relationship between the various forms of the czech language. Instead, I will investigate only one syntactic phenomenon which can be found in the spoken language (in both obecná testina and bežne mluvená cestina).

\subsubsection{Symtactic status of overt expletives}

The Czech personal pronouns are já ('I'), ty ('you'), on, ona. ono ('he, she, it') in the singular, and my ('we'), vy ('you'), and oni ('they') in the plural. In stylistically unmarked discourse, Czech (both literary and spoken) omits unstressed pronominal subjects. This is illustrated in the passage below taken from Heim (1982: 151).

(4) 1. Potkal jsem ho, práve kdyz vycházel z knihkupectví na Karlove náméstí.

2. Chodili jsme spolu skoro hodinu.

3. Najednou mi Y̌ekl, Ze musí na schùzi, そe prý už tam - tj. na druhé strane města - na něj někdo Łeká, a odběhl.

4. "Nikdy ho asi nepochopím", Yekl jsem si.

1. (I) met him, just when (he) came out of the bookstore at Charl's square.

2. (We) walked together for almost an hour. 
3. Suddenly (he) told me, that (he) must go to a meeting, and that someone is waiting for him there, that is on the other side of town, and (he) ran off.

4. "(I)'ll never understand him", (I) said to myself.

It has been shown in Chapter 3 that, with respect to the other two null-subject criteria, Czech also qualifies as a canonical null-subject language. Recall that, in Czech, overt pronominal subjects cannot act as bound variables, as illustrated in (5) and (6). Nor can they be interpreted as arbitrary in reference, as shown in (7).

(5) každý uxitel, si myslí, ze on.i/s má hloupého syna every teacher refl thinks that he has stupid son 'every teacher thinks that he (=some specific person) has a dumb son'

(6) Petr jestex stále miluje tu zenu, kterou si Peter still continue loves the women whom refl

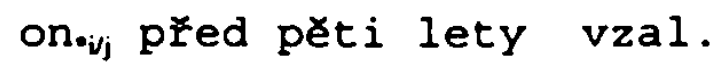
he ago 5 years took

'Peter still loves the woman whom he (=that other man) married 5 years ago'

(7) v Německu ^oni rádi pijou teské pivo in Germany they gladly drink Czech beer ' in Germany people like to drink Czech beer'

In section 4.3. following Faska (1964), a list of three environments was given in which Sorbian strongly prefers overt thematic subjects. They are repeated below under (8). 
(8) An overt pronominal subject is preferred in Sorbian a) if direct or indirect speech is being introduced b) if the matrix subject is a demonstrative c) if the matrix subject is a full NP

In Czech, on the other hand, overt pronouns are not at all privileged in those environments, but instead are avoided as shown in examples $(9-12)$. Environment (8c) directly violates one of the null-subject criteria. Example (9) below is thus related to the sentence type illustrated by (5) and (6) above. Sentences (10) and (11) contrast with (8a), and (12) contrasts with (8b).

(9) mí rodice łekli, Ze płijdou zitra

my parents said that will-come tomorrow

'my parents said, that (they) $)_{\text {ij }}$ will come tomorrow'

(10) Ikal, ze je unavený

said mesc that aux $_{3,8}$ tired $_{\text {mex }}$

' (he) said that (he) is tired'

(11) "nebojím se niðeho", Fekl

not-afraid ss $_{\text {- refl nothing said }}$

" "(I) don't fear anything", (he) said'

(12) ta rakla, Ze je unavená

that fem $_{\text {said }}$ rem that aux $_{3 \text { s }}$ tired $_{\text {fem }}$

'that one said that (she) is tired'

These facts further support the claim that Czech is a canonical null-subject language, in contrast to Sorbian. 
However, elements which appear to be overt expletives do occur frequently in spoken Czech. ${ }^{6}$ Overt expletives are not found in stylistically neutral written texts; however, they can occur in text types which in general try to imitate the spoken language. Schalich (1970: 78-79), for example, shows how expletive pronouns are used as "expressive means of language" in modern Czech comedies.

There have been very few attempts thus far to account for this phenomenon. Trávnicek (1962) deals with it from a diachronic perspective, while Koenitz (1988) and Hirschova (1984) try to provide an account within the framework of functional sentence perspective. Both analyze the expletive as either belonging to the thematic part of the sentence or marking the actual (very general) theme of the sentence. Franks (1995) and Lindseth (1994) are the only analyses within government binding, and Woolhiser (1994) provides a general survey of the syntactic and semantic characteristics of expletive-like pronouns in several slavic languages.

Expletives in spoken Czech are optionally overt, so this is not an instantiation of the fourth language type characterized as impossible in the identification/licensing model. However, the linguistic facts seem to contradict previous predictions, e.g. Hyams's, about the complete absence of overt

6 Townsend (1990) points out that there is a higher frequency of overt referential pronouns in the spoken language. This is not too surprising, considering that more emotive/subjective factors enter into this type of speech. 
expletive subjects in a language with null referential pronouns. The examples below illustrate this phenomenon, which poses an interesting problem for the licensing/identification framework. In none of the sentences is the subject assigned a thematic role. The subject position thus seems to be occupied by an expletive pronoun. The form of the Czech expletive pronoun ( $v$ ) ono is identical to the personal pronoun of the third person singular neuter.'

(13) a. vono je chladno

'it is cold'

b. vono jeste præ̌

'it is still raining'

c. vono se blýská

'it is lightening'

(14) a. vono se tam nepracuje

it refl there not-works

'no work is being done there'

(cf. Es wird dort nicht gearbeitet)

b. vono se tu tancuje

it refl there dances

'dancing is going on there'

(cf. Es wird dort getanzt)

7

One obvious phonological feature of Common czech in contrast to standard Czech is the use of a prothetic consonant [v] before initial o in most native Czech words, including the third person pronouns. Ono thus becomes vono. Hammer (1985) points out that in colloquial Czech this feature is used by virtually all speakers when it comes to pronouns and prepositions, but that its use in other words is more sensitive to the topic of the conversation, the type of words, the background of the speaker, etc. Townsend $(1990: 36)$ calls the prothetic shift $0>$ vo "the most important SPC (Spoken Prague Czech) feature and certainly the most difficult to analyze". presumably because of the multitude of factors which influence its use. 
(15) a. vono je možný, ze tam nepłijede

it is possible that there not-comes

'it is possible that he/she doesn't get there'

b. vono je přece nutný, abysme jí to řekli

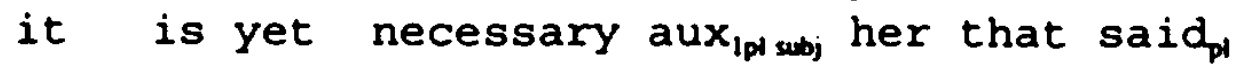

'it is after all necessary that we tell her'

c. vono se zda, Ze to nebude lehký

it refl seems that this not-will-be easy

'it seems that this is not going to be easy'

An immediate question is whether or not these expletives are really subjects. Of course, the answer to this question will depend on our definition of subject. Within Government Binding theory the notion of subject is defined configurationally as the NP which occupies the specifier position of IP. ${ }^{8}$ First of all, I assume that expletives have the categorial status of NPs and are not some sort of particle or adverbial. They are thus eligible to occupy subject position. This assumption is based on the fact that their form coincides with that of the third person neuter personal pronoun, and, in the examples above, they seem to correspond to overt non-referential subject pronouns in non-null-subject languages (it in the English translation of the examples above). If the expletive is in subject position, then we would expect it to be compatible with material in $C$ or [Spec, CP], as is the case for a normal

8 Under the split-INFL hypothesis, the subject position would be [Spec, AGRP]. However, this distinction has no bearing on the current discussion. 
subject. The tree in (16) illustrates this for some English examples.9

I know

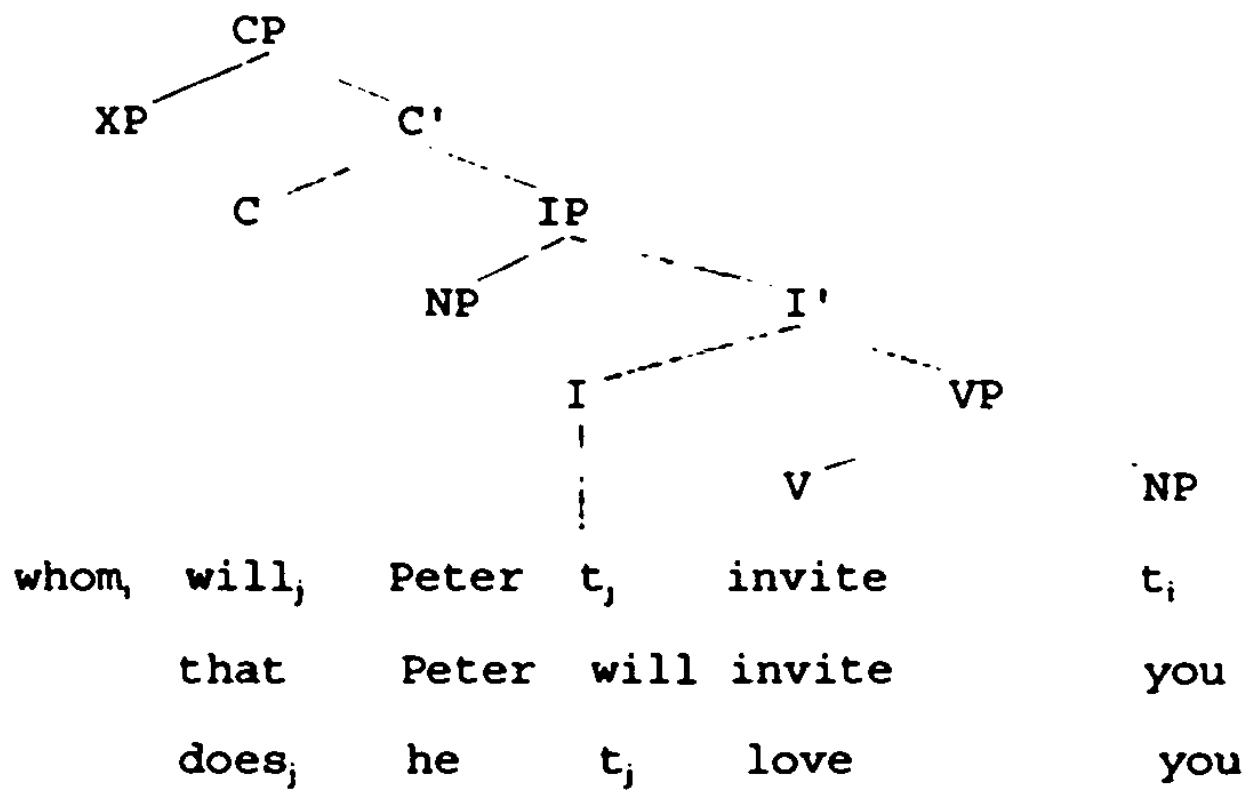

For one thing, expletives in Czech seem to be more or less restricted to sentence initial position, which could be taken to indicate that they occupy the specifier of $\mathrm{CP}$ instead of [NP,IP]. If they are not structural subjects, then they should not cause any trouble per se for the licensing/identification framework, since there could still be an empty NP (pro) in [Spec,IP] (with the non-referential element occupying a different position "further up" in the sentence). 10

9 In English there is a restriction that a wh-word in [Spec, CP] and an overt complementizer under $C$ cannot co-occur. In the literature this constraint is referred to as the "Doubly-filled COMP filter", dating back to a time when [Spec, CP] and $C$ were not clearly distinguished. In several other languages, e.g. in Dutch and in Bavarian German, the sequence of $a$ wh-word and a complementizer is possible.

10 For example, one subtype of German non-referential es as in (i) seems to be restricted to [Spec,CP], and is thus incompatible with wh-words such as wann ('when'), as shown in 
The examples below were judged by native speakers for their grammaticality. The complementizer protoze in (17-19), $k d y z$ in (20) and the preposed verb nepracovalo in (21) occupy C, while the question words in $(22-24)$ are in [Spec,CP] .

(17) nemúžu jit ven, protože vono tam prş not-can go outside because it there rains - (I) can't go outside, because it is raining there'

(18) nikdo tu nebyl, protoze vono se tu nobody there not-was because it refl there veera nepracovalo yesterday not-worked

'nobody was there because there was no work being done yesterday'

(19) protoze vono se zda, Ze to nebude lehký because it refl seems that this not-will-be easy 'because it seems that this is not going to be easy'

(20) ?? nemúžeme tady být, kdyz vono se tu nepracuje

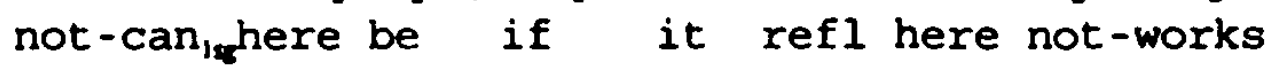
'we can't be here, if there is no work being done'

(ii). (See also the discussion in section 5.3.3.)

(i) es wurde wie immer viel gelacht und gesungen 'there was as usual a lot of singing and dancing going on'

(ii) *wann wurde es wie immer viel gelacht und gesungen? Under this analysis sentence (i) actually has an empty NP (pro) in subject position, as illustrated in (iii).

$$
\begin{array}{lll}
\mathrm{XP}-\stackrel{C P}{C}-C^{\prime} & \\
i & \mathrm{NP} & \mathrm{VP}-I^{\prime} \\
\text { es wurde } & \text { pro gelacht } \quad t_{i}
\end{array}
$$


(21) ?? nepracovalo se vono vcera?

not-worked now $_{\text {refl }}$ it yesterday

'wasn't there any work done yesterday'

(22) *kde je vono chladno

'where is it cold'

(23) *kdy vono pršl/prş vono

when it rains/rains it

'when is it raining'

(24) „prot vono se tu vera nepracovalo

why it refl here yesterday not-worked

'why wasn't there any work done yesterday'

At first glance, the results of this investigation seem to contradict each other. Native speakers were quite willing to accept complementizers (especially protože) preceding vono; however, constructions with material in [Spec, CP] were rejected. As I will discuss below in section $5.2 .2 \ldots$ the marginality or unacceptability of sentences $(20-24)$ may be due to pragmatic rather than syntactic reasons. I thus claim, based on the compatibility between vono and material in the complementizer position $C$ in examples (17-19), that expletives in Czech are indeed in subject position."

The Czech expletive is not only used in impersonal constructions, such as impersonal passives and weather verbs, but

"Within the typology proposed by Franks (1990), spoken Czech is thus an example for [-OSP, +OSP]. 
it can co-occur with overt referential NP subjects, as shown in $(25-32) .12$

(25) vona ta mylenka ma neco do sebe expl.rem this thought rem has something to itself 'this thought has something to it'

(26) vona se Mařonka stará vo v̧̌echno expl.femrefl Małenka fom takes-care of everything 'Małenka takes care of everything'

(27) vona se tu naskytla ta vosoba expl.rem refl there appeared that person 'there appeared that person'

(28) von mu otec vłechno dovolf expl.max him father everything allows

'father allows him everything'

(29) von ho nemine trest expl.max him neg-spare punishment max $_{\text {max }}$ 'punishment won't spare him'

(30) vono tam bylo moc lids expl. now there was man $_{\text {man }}$ people 'there were many people there'

(31) vono se ti to lhani jednou vymsti expl.nax refl. you da this lying nam $_{\text {once }}$ revenge 'this lying will come back to haunt you sometime'

(32) von byl driv vchod $z$ druhý strany expl.mexwas once entrance from other side 'there used to be an entrance from the other side' from Koenitz (1988), example (27) from Schalich (1970), example (28) and (29) from Siebenschein's dictionary (1983), examples (30) and (31) from Hirschova (1984), example (32) from Townsend (1990). All examples were tested on and accepted by native informants. 
There is no intonational break between the pronoun and the rest of the sentence, which indicates that this is not some type of left-dislocation. ${ }^{13}$ Moreover, the expletive in such constructions agrees with the associated referential NP in pronominal features. We thus have feminine vona in (25), (26), and (27), masculine von in (28), (29), and (32), and neuter vono in (30) and (31). Example (30) is interesting with respect to agreement. It contains a quantified NP in the genitive case, so that default neuter singular agreement appears on the pronoun. The finite verb bylo is also in the neuter singular form. Both the expletive and the thematic NP appear in the nominative case.

Expletives in this construction are for the most part compatible not only with overt material in $C$, as in examples (33) and (34), but also in Spec-CP, as shown in $(35-37)^{14}$.

(33) myslím, Ze vona ta troje myłlonka má nĕco do sebe 'I think that your thought has something to it'

13 In left-dislocation constructions, an NP is adjoined to the left of IP and picked up again by a coindexed NP, as shown in the example below.

binding principles, I cannot figure them out

Coindexation of left-dislocation constructions is not a violation of principle $B$ or C (a pronoun has to be free in its governing category; an R-expression has to be free everywhere), since the binding theory applies to A-binding only and the antecedent in the left-dislocation construction occupies an $A^{\prime}$ position.

if For glosses compare examples (25)-(28). 
(34) ... protože vona se Max̌enka stará vo všechno 'because M. takes care of everything'

(35) najednou vona se tu naskytla ta vosoba 'suddenly that person appeared there'

(36) kdy vona se tu naskytla ta vosoba 'when did that person appear here'

(37) prot von mu otec vsechno dovols 'why does dad allow him everything'

Based on these facts, I conclude that the expletive is in [Spec,IP]. The unexpected compatibility of the expletive with material in [Spec.CP] in this construction type (in contrast to the vono prsi/vono se tu nepracuje type of construction) will be discussed in 5.2.2.

The next question which arises is which structural position the referential nominative NPs in this "double subject" construction type occupy. According to Sportiche's (1988) VPinternal subject hypothesis, all arguments, including the subject, are projected in the VP. Thus there is another subject position, namely [Spec,VP], which is assumed to be the Dstructure position for all thematic subjects. I propose that the referential subject NPs in the examples under (25-37) actually remain in Spec-VP at $S$-structure. This is illustrated in $(38) .15$

is At LF the referential NP moves up to spec-IP to adjoin (or replace) the expletive, so that no violation of the principle of full interpretation occurs, according to which LF may only contain elements which contribute to the semantic interpretation. 
(38)

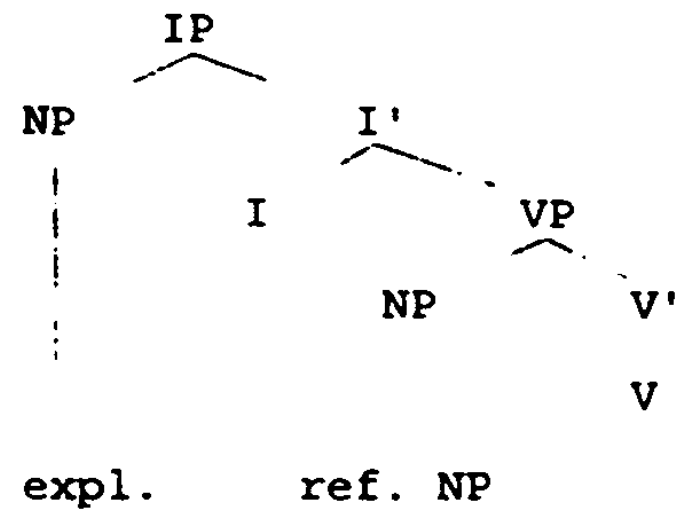

The expletive and the referential NP associated with it presumably form some sort of CHAIN at S-structure. The members of this chain share pronominal features and case.

Alternatively, nominative case assignment to the expletive and the thematic pronouns could occur independently. As pointed out before, within recent analyses it has become standard to assume that what was formerly IP should be split into several specialized functional projections of $V$, such as AGRP, TP, NegP etc. Let us further assume with Roberts (1993: 27) that either AGR or I can assign nominative case as a matter of parametric choice. According to Roberts, Agr can assign case under spec-head agreement or government ECM; however, T can only assign case under government ECM. ${ }^{16}$ It is thus conceiv-

16 ECM = Exceptional Case Marking. This case marking is "exceptional" because the case assigning head $X$ assigns case to the specifier position of a maximal projection YP. Maximal projections normally constitute barriers for case assignment from outside.
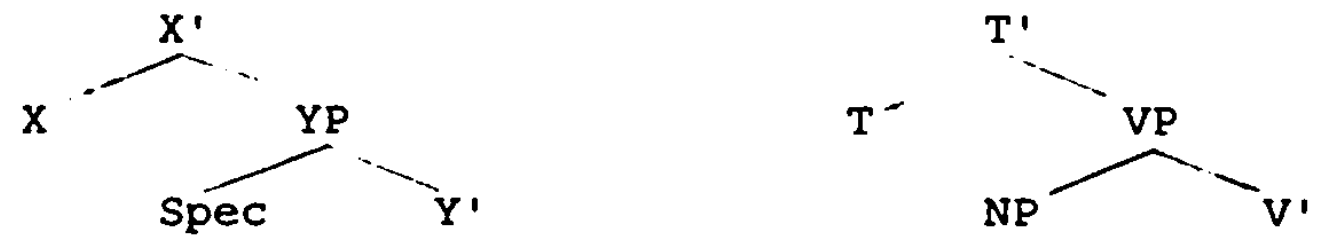
able that in some languages, including under this analysis Czech, T assigns nominative case under government of the subject NP in spec-VP. At the same time, AGR is able to assign nominative to its specifier, occupied by the expletive, under spec-head agreement. ${ }^{17}$ This alternative explanation of how nominative case assignment can be accounted for in the Czech double-subject construction is shown in (39).

ArgP

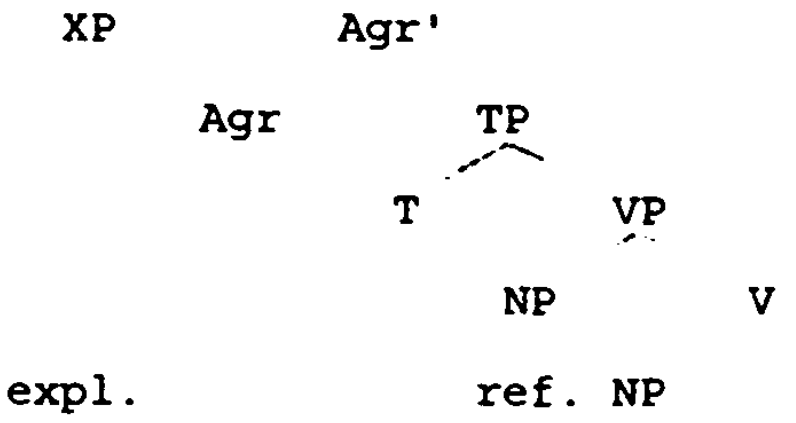

17 In principle, we could expect that a subject can use different spec positions as landing sites, probably with cross-linguistic variation. Furthermore, it should be possible to independently lexicalize more than one specifier position within the (old) IP domain, as has recently been argued for Icelandic (Jonas \& Bobaljik 1993) and Finnish (Holmberg \& Nikanne 1994). An alternative interpretation of the Czech construction type with expletive and associated thematic subject might then be that the referential subject occupies Spec-TP. Further research will have to show whether or not this is a viable option. It is far from incontravertible that all the different functional projections of $v$ really exist. It would be convenient to prove that there is actually some "use" for the different specifier positions, such as Spec-TP or Spec-NegP. 


\subsubsection{Origin and meaning of Czech expletives}

In the previous section I argued that expletive pronouns in Czech occupy the structural subject position. We have thus found a counterexample to Hyams's (1986) prediction that languages which use referential pronouns for functional rather than grammatical reasons (i.e. null-subject languages) do not have overt expletive pronouns. Czech is a canonical nullsubject language which nevertheless uses lexical expletives.

However, it needs to be mentioned that most of the Czech constructions without expletives are not entirely synonymous with those which do have expletives. In fact, there seem to be three different types of expletive constructions.

The first group includes meteorological verbs and impersonal passives, as illustrated in (13) and (14) above. Here, an overt expletive is invariably associated with an emotive involvement of the speaker, and always implies some sort of emotion such as surprise, joy, disappointment, etc. Above I analyzed vono type expletives as structural subjects, despite the fact that some speakers find the co-occurrence of such expletives with material in $C$ awkward and most speakers even reject their co-occurrence with question words in CP. It seems to me that such incompatibilities can be attributed to pragmatic rather than syntactic considerations. A sentence such as Vono prgf expresses surprise on the part of the speaker about the fact that it is raining - something like the 
English 'Wow it's raining!'. It would not make much sense to turn this into a question *'When, wow, is it raining?'.

The same native speakers consulted about the first type of construction also agreed that the expletive in the subject doubling construction in examples (25-32) does not necessarily contribute the same kind of emotive emphasis as the vono in the impersonal constructions. ${ }^{18}$ Instead, this type of construction seems to be used primarily to lower the style intentionally, depending on the speech situation, although a certain emotional involvement may also pertain. These findings are confirmed by Schalich (1970: 79), who writes about the role of this type of construction in the comedies of the Czech writer Karel Capek (1890-1938) among others.

Es [the pronoun] ist hier ein rein aktualisie-rendes Element, das der Ảußerung eine persőnliche, leicht vertrauliche Note gibt und zugleich die Eindringlichkeit des Gesagten erhōht ... Im authentischen Dialog ist diese Diktion bisweilen durch ein verstårktes Kontaktbedūrfnis des Sprechenden motiviert. ${ }^{19}$

18 This seems to be more or less confirmed by other authors. Koenitz (1988) and Hirschová (1984) claim that vono type expletives in general have no emotive function. However. their analyses focus primarily on the subject doubling type Von mu otec všchno dovolí as in example (28).

19 'It [the pronoun] is here purely an actualizing element which lends a personal, slightly intimate touch to the statement and at the same time increases the forcefulness of what has been said ... In authentic dialogue this diction is occasionally motivated by an increased desire for interaction on the part of the speaker.' 
Examples (29) and (31) above were generally interpreted as having an additional emotional nuance of warning or threat, as if the overt pronoun von/vono expressed a kind of "just you wait" attitude on the part of the speaker. However, the main function of the overt expletive appears to be to mark the discourse as more informal or friendly. It may be exactly the lack of a clear emotive emphasis in most sentences of this type which allows the expletive in this construction type to co-occur with wh-words, as illustrated in examples (36) and (37) above. 20

The third type of construction was shown in the examples under (15). Here, the pronoun vono is associated (coindexed) with an extraposed finite clause. It seems to me that in these cases vono has actually more of the "pointing" function of a demonstrative and is thus not non-referential as such. In this type of construction vono can be replaced with the demonstrative to without any change in meaning.

(15') vono/to je možný, ze tam nepłijede

'it is possible that he/she doesn't get there'

The use of pronouns in this position has been reported for other Slavic languages which otherwise do not allow overt expletives. Franks (1990) reports that in Russian the neuter demonstrative èto can be used in these contexts. Furthermore,

20 Most informants also rejected variants of the emotionally colored examples (29) and (31) when material other than the complementizer protože preceded the expletive. 
a demonstrative pronoun to is marginally possible in the same type of construction in Serbo-Croatian and Polish. The fact that these languages use a demonstrative instead of the $3 \mathrm{rd}$ person pronoun in this construction indirectly supports my argument about the pointing function of czech vono. The following examples are taken from Franks (1990: 19-21).

(40) (èto) xorošo, tto Ivan pošèl domoj

' (it) is good that $I$. went home'

(41) ?(to) je dobro, sto Jovan ide kuci

' (it) is good that $J$. is going home'

(42) ?(to) jest dobrze, ze wszyscy poszli do domu [PO] '(it) is good that everybody went home'

An optional use of the pronoun es can also be observed in German. As will be discussed in more detail in 5.3.3. German has obligatorily overt quasi-argumental subjects (weil eg/»pro regnet) and obligatorily null non-argumental subjects (weil pro/*es hier getanzt wird). However, in the context of an extraposed finite clause this complementary distribution seems to break down. Both the variants with and without es are possible, as shown in the sentences below.

(43) ... weil möglich ist, daß er morgen kommt

... weil es möglich ist, daß er morgen kommt

...'because (it) is possible that he comes tomorrow'

(44) ... weil schön ist, daß du morgen kommst

... weil es schön ist, daß du morgen kommst

...'because (it) is nice that you will come tomorrow' 
I thus argue that the occurrence of vono in the construction type with an extraposed finite clause represents a different phenomenon which is not immediately related to the possibility of overt expletives in a language. However, taking into account the fact that the acceptability of the constructions in Serbo-Croatian and Polish is at best marginal, the occurrence of "real" expletive subjects in Czech may well affect the use of vono in these constructions. ${ }^{21}$

The functions of the expletive in the first and second type of construction are related in that they express the involvement/attitude of the speaker. This sheds doubt on Hyams's (1986) position that non-referential elements (i.e.

21 Franks (1990) treats the pronouns in constructions with extraposed finite clauses as "true" expletives. Recall that he derives the null-subject properties of a language from its nominative case assignment properties (Nominative case must be realized? [OESP]; Nominative case cannot be assigned at LF? [OSP]) Null expletives are generally irrelevant for the LF-visibility of arguments. If a language does not obligatorily assign nominative case, expletives in that language do not get case and thus cannot be lexicalized. However, Franks predicts that a certain type of overt expletive should be possible even in [-OSP,-OESP] languages. Clausal and prepositional complements also need case for their theta-roles to be visible at LF. While infinitivals and PPs have intrinsic case, finite complement clauses must form a chain with the subject position which receives nominative case. The expletive in the theta-marked chain with a finite clause will thus receive case as well. At this point the expletive pronoun is like any referential pronoun which must have case for LF-visibility but does not need to be lexicalized due to the [-OSP] setting. It may, however, be lexicalized.

Although not explicitly mentioned by Franks (1990), the difference in the acceptability of such elements in Czech on the one hand, and Polish and Serbo-Croatian on the other, might be attributed to the fact that Czech is [-OSP,+OESP] and thus allows optional expletives in general. 
expletives) cannot be used for functional/pragmatic purposes. Instead, I claim that overt expletives in Czech should be subsumed under the generally possible occurrence of overt subject pronouns in marked discourse. Just as with referential subject pronouns, the use of an overt expletive is evoked by functional considerations. One might interpret lexicalized subject pronouns in Spec-IP (i.e. [Spec, AGRP]) in null-subject languages as an overt realization of the pronominal features of Agr to specially mark the discourse.

The occurrence of overt expletives in Czech can thus be shown to be compatible with the avoid pronoun principle. Recall that the use of overt referential pronouns did not contradict the principle, as long as they were used in emphatic contexts. Similarly, by the avoid pronoun principle, a language that licenses null subjects will never use overt expletives unless they convey some special pragmatic meaning. Within the scope of this work I will not attempt to analyze the different shades and nuances of this pragmatic meaning. In the following I will use "emphatic expletives" as a general term. Spoken Czech is special in having such expletives. The question as to why expletives in Czech, in contrast to other null-subject languages such as Italian or Spanish, are not really meaningless will be discussed below.

The table below is an "updated" description of possible language types within the licensing/identification framework (cf. also Table 1). It should be emphasized that the following 
combinations are not parameter settings, but instead descriptions of possible language types derived from the settings for the actual parameters [pro licensed] and [pro identified] . ${ }^{n}$

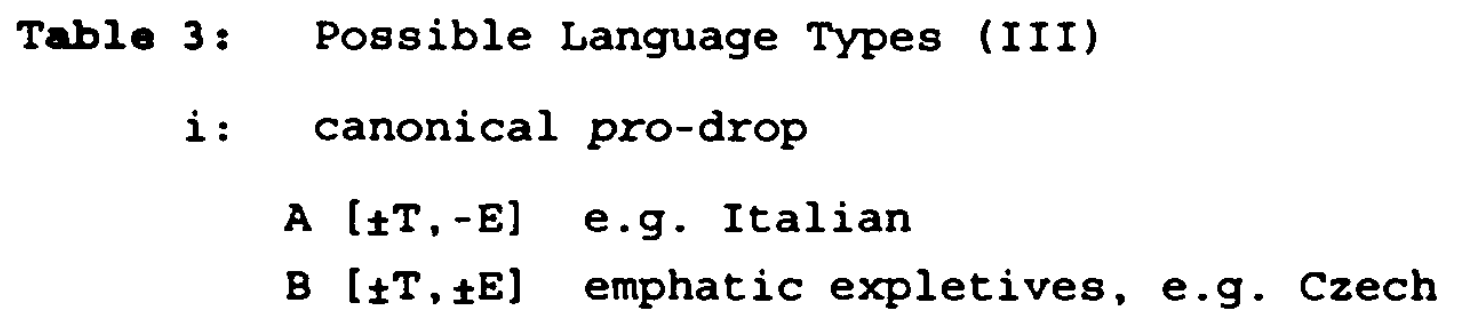

ii: mixed languages
C $[+T,-E]$ e.g. Russian, German 23
D $[+T, \pm E]$ e.g. ??

iii: canonical non-pro-drop

E $[+T,+E]$ e.g. English

Types $A$ and $B$ are canonical null-subject languages in the sense that pro is licensed and identified. Both type $C$ and $D$ belong to the mixed type, i.e. pro is licensed but not identi-

22 I take '+' to mean obligatorily overt, '-'obligatorily null and ' \pm ' optionally overt. ' $T$ ' stands for 'thematic subjects', 'E' for 'expletive subjects'.

23 Although both German and Russian are mixed pro-drop languages, they are still different with respect to their null-subject properties. In German, quasi-argumental subjects have to be lexicalized, while in standard Russian they must be pro, as illustrated in the contrast between (i) and (ii).

(i) ...weil es/*pro hier kalt ist 'because it is cold here'

\section{(ii) ...potomu tto "ono/pro zdes' xolodno}

As mentioned in the introduction, quasi-argumental subjects share properties of both referential subjects and expletive subjects, so that such a cross-linguistic "vacillation" with respect to overtness or covertness should not be too surprising. 
fied. In contrast to type C, type D would be a mixed pro-drop language with emphatic expletives. As of yet, this type has not been attested, although it is theoretically possible. ${ }^{24}$

The discussion thus far has shown that the Czech data can actually be accounted for by the licensing/identification framework and that the occurrence of optionally overt expletives in a language which licenses pro does not necessarily constitute a violation of Chomsky's avoid pronoun principle.

At this point it seems appropriate to point out some similarities and differences between the predictions made by the (modified) licensing/identification framework summarized in Table 3 and Franks's case-assignment based approach discussed earlier in this chapter (cf. Table 2). Both systems predict the existence of the Czech type, i.e. optionally overt expletives in a canonical null-subject language. According to an analysis à la Franks, spoken Czech has a different parameter setting than a null-subject language which does not allow overt expletives. Within a licensing/identification approach, there is no difference in the parameter settings, and spoken Czech is unusual in that it has emphatic expletives. So far, only very few nullsubject languages with overt expletives have been documented. For Franks, the question is why the setting [+OESP, -OSP] seems

24 Woolhiser (1994) mentions the occurrence of expletive pronouns in Ukrainian, Belorussian and Russian dialects. In Chapter 3 I analyzed Russian as a mixed pro-drop language. More research is necessary to determine whether or not these dialects may in fact be examples of language type $D$. 
to be so rare. $^{3}$ For my analysis, the exceptional status of Czech is justified by the fact that languages normally do not develop emphatic expletives. Franks's system, based on two binary parameters, predicts the existence of only four language types (cf. Table 2). Franks (1990: 14) mentions explicitly that the configuration which is predicted to be imposelble under his approach is a language with obligatorily overt thematic subjects and optionally overt expletives, which corresponds to type D in Table 3. The existence of mixed prodrop languages with overt expletives (which have not been attested yet) would thus disprove the case-assignment analysis. For Franks, the justification for overt expletives in a language is a setting of [+OESP], and it depends on the setting for the [OSP] parameter whether the expletives are obligatorily ([+OSP]) or optionally ([-OSP]) overt. Optionally overt expletives derive from the setting [-OSP,+OESP]. On the other hand, for a language to have obligatorily overt thematic pronouns, the setting [+OSP] (nominative assignment cannot take place at LF) is assumed, which leads to a contradiction.

Expletives by definition lack any referential properties. How is it then possible that such an element can carry a pragmatically marked reading? The following discussion and exam-

2s Unless, of course, we assume that even in this language type the overtness of expletives is conditioned by functional considerations. It could then be possible that there are many languages with the setting [-OSP.+OESP] which simply could not be differentiated from [-OSP, -OESP] languages due to their lack of emphatic expletives. 
ples are based on Trávnítek (1962: 16-30), who gives a plausible historical account of the use of expletive pronouns in Czech. He argues that the emotive/emphatic meaning developed out of the upozorrovach citoslovce ('attention interjection') ono/ano, which corresponds to modern Czech hle or aj ('look'; 'behold'). In older Biblical texts ono/ano was originally used as one of the possible translations of Latin ecce. This element had sentential value on its own and was therefore positioned "outside" the CP of the following clause. The Czech example in (45) illustrates this.

(45) James: $5: 7$

ano. těxằ đaká drahého óvoce (evangeliáł olomoucký, 14th century; cited by Trávnicek (1962: 20)) ecce agricola expectat pretiosum fructum 'see, the farmer is waiting for the precious fruit' -j. orát oxekává drahého uzitku zemského (Kralická Bible, 1613 edition)

Later, this element lost its original function and meaning. The development of its various emotional nuances was accompanied by the loss of its sentential value and incorporation into the sentence structure proper of the following sentence. The original intonational break between the interjection and the next sentence was lost. ${ }^{20}$ According to Trávnítek.

26 More evidence for the change in the status of ano/ono comes from the placement of clitics. Recall that Czech has second position clitics. Tránnitek (1962: 21) writes: 
agreeing forms, which in our terms reflect a movement "down the syntactic tree" into subject position, started to develop in the late 15th century. Examples (47) and (48) date back to the first half of the $16 t h$ century. There are also examples of non-agreeing ano/ono during the transitionary period, as illustrated in example (46) which dates back to the second half of the 14 th century. ${ }^{n}$

(46) ano vłak $i$ ta nama nebesa vyznávaji divy $i$ svatost jeho

'even the heavens confess his miracles and sainthood'

(47) a oni Polcicip volili jsú sobe za knize mladence jednoho

'and the Poles elected a young man as their ruler'

Kdyz citoslovce ztratilo vetnou platnost. vyslovovalo se splfrave $s$ následujici vétou a citilo se za jeji clen, zacaly se klást płiklonky hned za ne.

'When the interjection lost its sentential value, merged with the following sentence and was felt as its member, the clitics began to attach immediately following it [the original interjection, ML].'

Unfortunately, no examples of clitics and "independent" ano/ono are available at this point, so that example (i) is a theoretical reconstruction based on (ii) which is given by Tránicek (se is a reflexive clitic).

(i) ano, jiz se setmievá

'behold, it's already getting dark'

(ii) ano se jiz setmievá

27 These examples are cited from Trávnicek. The difference between the ano in (46) and (45) is somewhat difficult to prove. Travnitek bases his judgement on the lack of the comma in the former. A comma seems to be consistently present in the older examples where ano is still an independent citoslovecná vêta (interjectional sentence). 
(48) onipl véichni certipt vyšli sú z pekla pro tu duši 'all devils came out of hell for this soul'

In modern Czech agreement is more or less obligatory, unless of course there is no subject with which to agree, which próduces the vono pršl/vono se tu tancuje type. ${ }^{28}$ However, some modern dialects may have preserved an intermediate stage of this development with a non-agreeing form of the expletive. Travnitek cites, among others, the Czecho-Moravian dialects as an example, as shown in (49).

$$
\begin{aligned}
& \text { (49) vono Xasto lidi videli neco } \\
& \text { expl.nour.sg often people saw something } \\
& \text { 'people often saw something' }
\end{aligned}
$$

Trávnitek (1962: 25) calls the pronoun which evolved out of the interjection naladove on ('moody it') and maintains that it expresses the citove zaujetr ('emotive bias') of the speaker whenever it is used. While this is true for the vono prål/vono se pracuje type, it contradicts my findings somewhat as far as the double subject type is concerned. Recall that

28 I can only speculate about why this type of construction is not part of the modern spisovná cestina. One important source for the codification of the literary language in the early 19 th century was the Kralice Bible from 1593. which was based on the Moravian dialect. (Kralicy is a town in Moravia). I did not find a single example of subject doubling constructions in the Gospel according to st. Matthew as translated in the Kralice Bible, which leads me to conclude that this type of construction in general was not typical for this Bible translation. Recall that the phenomenon of overt expletives was discussed as a feature of the spoken language (obecná đeština or bèznè mluvená cestina) of Bohemia. 
most speakers agreed that the expletives in examples $(25-32)$ above do not necessarily contribute an emotive emphasis. However, it is possible that the naladový odstín ('emotional nuance') has further changed in the thirty years since Travnitek wrote his book.

As for the use of vono in constructions with extraposed finite clauses, I speculate that this function dates back directly to the original common slavic demonstrative pronoun onb, ona, ono. Common Slavic had no 3 rd person pronouns, and it was this demonstrative which developed into 3rd person pronouns in most slavic languages. Czech is unusual in that it seems to have had an additional source for the 3 rd person pronoun, namely the upozorriovaci citoslovce mentioned above. ${ }^{20}$

\subsection{Opper Sorbian}

In Chapter 4 I argued that Upper Sorbian does not behave Iike a canonical null-subject language with respect to the occurrence of referential null pronouns. Sorbian thus produces a serious challenge for a licensing/identification approach to null-subject phenomena. In this section I will investigate whether or not the licensing/identification theory, especially

29 Trávincek seems to imply that all 3rd person pronouns are derived from the original interjection ono/ano (which in turn is most likely derived from the Common slavic demonstrative pronoun onol. He maintains that the double subject constructions occurred at a time before the appearance of normal 3 rd person pronouns and basically paved the way for their introduction into the language. 
the morphological uniformity hypothesis, makes correct predictions about non-referential subject pronouns in Sorbian.

\subsubsection{Syntactic status of overt expletives}

The Sorbian verbal paradigm fulfills the morphological uniformity criterion, and thus we would expect pro to be licensed. In keeping with Chomsky's avoid pronoun principle and based on the discussion in section 5.2.2. we would then expect that the language should not use overt expletive subjects unless they are able to fulfill some sort of pragmatic function, as we have seen in spoken Czech.

Overt non-referential pronouns are widely used in spoken Sorbian, although they are more or less absent from the literary language. Schuster-Sewc (1974) was, to my knowledge, the first linguist to attempt to give a systematic account of this phenomenon. A discussion of several aspects of his article will be included in this section.

The different forms of the expletive are wono and wone. These forms are distributed according to dialectal areas. Wono is typical for Lower Sorbian, the transitionary dialects (Muskau, Schleife, Spreewitz, Hoyerswerda), and the Northern dialects of Upper Sorbian (Nochten, Reichwalde, Klitten, Kreba), and wone for most other Upper Sorbian dialects. ${ }^{30}$ In

30

Schuster-Sewc (1974) points out that the form wone is a secondary form derived from wono. probably under the influence of the distinction between to and te for the nominal and neuter attributive use of the demonstrative pronoun. 
the South-Eastern tip of Lusatia the form won, which is homonymous with the 3 rd person masculine form, is used as a nonreferential pronoun instead of wone. This phenomenon seems to be strictly limited to a very small area, and speakers from other dialect zones reject it outright. The examples (50-57) below were collected in the "Kerngebiet".

(50) Jana je prajila, zo chce wona rady kupac hic. 'J. said, that she would like to go swimmming.' Wone pak je hikre płezyma. it however is still too-cold 'However it is still too cold'

(51) wone je ßkoda, zo wjeðor njepłindkeళ it is pity that evening not-will-come 2 s 'It is too bad that you won't come in the evening'

(52) woe njeje rjenje, zo je płeco hiłce tak zyma it not-is nice that is always still so cold

'it is not nice that it is still so cold'

(53) poprawom smy chcyli dkensa pucować, ale wone at-first aux $x_{1 p 1}$ wanted today hike but it so nazel descuje refl unfortunately rains 'originally we wanted to go for a walk today, but unfortunately it is raining'

(54) wone je mózno, zo wón hiše płindze it is possible that he still will-come 'it is possible that he will still come'

(i) to ma chwile 'this had time'

(ii) te blido 'this table' Wone first appears in Swetlik's 1690 Bible translation. 
(55) My hakle jara pozdźe do wjeski płińdzechmy, we only very late to village came

a wone bð̌̌e hižo ćma. Wone njebł̌e nam cyle derje. and it was already dark it not-was to-us quite good 'We came into the village very late and it was already dark. It was a little scary.'

(56) dzensa so prózdniny zapocnu; wone je tež wulki לas today refl vacation start it is also high time 'today the break starts; it is also high time'

(57) wsitcy bechu wjeseli; wone je so wjele smjelo, all were happy it was refl much laughed rejwalo a spěwalo danced and sung

'everybody was happy; there was a lot of laughing. dancing, and singing'

Consultants with some degree of formal language training, such as teachers, ministers, and clerical workers, claimed not to use this sort of construction, but did not deny familiarity with the phenomenon. Prof. Helmut Faßke of the sorbisches Institut analyzed native speakex recordings of spontaneous speech from a large variety of dialects in preparation for the syntax volume of the Sorbischer Sprachatlas (Volume XV to appear) and kindly shared some of his data with me. The following examples are taken from these recordings."

(58) wono jo se tak wjele šlo, zo sycko spódy wody stoj 'it rained so much that everything was under water' 
(59) wono bylo zon jare pozdze 'it was already very late'

(60) pon bu wone wordowalo mudrowane a powedane 'then there was a lot of smart talking'

(61) wone je dźensa jara malo widzeć 'there is very little to be seen today'

(62) ale wone bð̧̌e nuzne, zo so ta rěka zahąi 'but it was necessary to dam up that river'

(63) wone dyrbjeక̌e Čisce znowa zapocane wordowac 'it had to be started all over again'

(64) ale wone tez skoro zas tak je kaz pojeda 'but it is also almost as they say'

(65) won be to pon tak daloko płiblo, zo ... 'it went so far that ...'

Based on the discussion in section 5.2.1., the pronouns in examples (51), (52), (54), and (62) should perhaps not be interpreted as "pure" non-referential pronouns, and instead be seen as being similar to the Czech vono co-occurring with extraposed finite clauses. In the following I will concentrate on the other environments in which the expletive-like elements seem to occur.

The use of non-referential pronouns is optional. In clear contrast to Czech, no emotive/emphatic component is associated with the use of these expletives. Thus, if they turned out to be "real" subjects this would be in conflict with the theoretical predictions outlined above. In particular, we would have found a language which lexicalizes non- 
emphatic expletive subjects, although pro is licensed.

However, in contrast to czech, there seems to be a syntactic incompatibility between expletives and wh-phrases or complementizers. This hypothesis is supported by evidence from various sources. Faßke's corpus of data, for example, provides over 50 examples of overt expletives in many different dialect areas. However, only a single case can be found where wone was used after a complementizer. I also asked informants to translate sentences containing overt expletives from German into Sorbian. There was not a single instance in which speakers used an overt expletive after a complementizer or wh-word, even if there was an es in the German original. 32 The sentences below, produced by an informant who tended to use overt expletives very frequently, illustrate this.

(66) wone pak je hiše prezyma

it however is still too-cold

'it is still too cold'

(es ist aber noch zu kalt)

(67) mi je žel, zo preco hił̌ce tak zyma je me is sorry that always still so cold is 'I'm sorry that it is still so cold' (mir tut es leid, daß es immer noch so kalt ist)

All Sorbian speakers rejected constructed examples where wone/wono was used after a wh-word or complementizer. This is shown in examples (68) and (69). 
(68) hdy (*wone) je zyma

' when is it cold'

(69) dદeci su zrudne, dokelz (*wone) hižo taje 'the kids are sad because it is already thawing'

In contrast to Czech, in Sorbian there is a very clear syntactic incompatibility between overt expletives and overt material in the head or specifier of CP. In view of the lack of any sort of emotive component inherent to these pronouns, it is not an option to attribute these distributional restrictions to pragmatic reasons. This leads me to conclude that Sorbian expletives are positioned outside [Spec,IP], most likely in [Spec,CP]. Presumably, pro is occupying [Spec, IP] even if an overt, non-referential wone/wono is present, giving the structure (70) below.

$(70)$

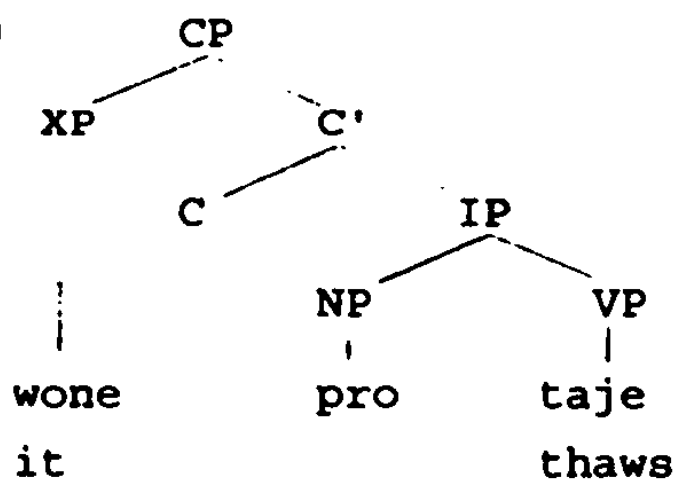

To continue this line of reasoning it is useful to look at the two different types of conjunctions. Subordinating conjunctions such as dokelz ('because') in example (71) reside in the complementizer position $C$ and take a subordinate clause (IP) as complement. The expletive wone, occupying [Spec,CP] 
lies outside this IP, and a complementizer placed in front of wone would thus lead to branch crossing and therefore violate $\mathrm{X}$-bar structure. ${ }^{33}$ Coordinating conjunctions such as ale ('but'), on the other hand, conjoin two elements of identical category, such as two CPs and should therefore not inhibit the occurrence of the expletive wone. This expectation is borne out by the next pair of sentences, produced by the same informant (sentence $(53)$ is repeated as $(72)$ ).

(71) wón njeje kopańcu hrac sol, dokelž he neg-aux ${ }_{3 s}$ soccer play went because je so descowalo aux $_{34}$ refl rained

'he didn't go to play soccer, because it was raining'

(72) poprawom smy chcyli dźensa pucowac hic, ale wone so nažel descuje

'originally we wanted to go for a walk, but it is unfortunately raining'

A curious type of construction was discovered in a dialect text from the Mješicy region, cited by Faßke and Michalk (1989: 41). Example (73) is an arbitrary plural construction

33 The sequence 'wone dokelz', although theoretically conceivable in terms of the tree structure, is not possible. Also compare the ungrammaticality of the German sentences below :

(i) *weil es getanzt wird

'because it is being danced'

(ii) ^es weil getanzt wird 
with a 3rd person singular expletive in initial position. ${ }^{3}$ This indirectly supports my hypothesis that the overt expletive in Upper Sorbian is not in [Spec,IP] ([Spec, AGRP]), since, otherwise, we would be faced with a very unusual situation of non-agreement between the singular pronominal subject won and the plural verb su pojdali.

$$
\begin{aligned}
& \text { (73) won su jow wele pojdali, zo } \\
& \text { expl.ss auxp here much said that } \\
& \text { 'one used to say here often that' }
\end{aligned}
$$

An analogous example was found among the tapes analyzed by Faßke, cited here as (74).

$$
\begin{aligned}
& \text { (74) won to takle tinjachu } \\
& \text { expl.s that so did pl } \\
& \text { 'it used to be done that way' }
\end{aligned}
$$

\subsubsection{Hietorical perapective}

It follows from Seiler's (1830: 113-114) description of the phenomenon that the situation in the early 19th century seems to have been more or less the same as in today's spoken language.

Das unbestimmte Pronomen und unbekannte Subjekt Es wird durch wono oder wone gegeben, welches dann das erste Wort zu sein pflegt: wono rima, es donnert; wono $s$ deక̌om a se snehom dke, es regnet und schneit zusammen; wone zwoni, es lăutet; wone so wujasnjuje,

34 Mjesicy (Meschwitz) is in the Sorbian speaking territory which uses the form won as an expletive pronoun (see 5.3.1.). 
es hellt sich auf. Da aber schon die dritte Person singul. neutr. des Zeitworts das Es bezeichnet, so wird in Sätzen, wo Konjunktionen oder andere Redetheile voranstehen kőnnen, wono weggelassen: hdyz rima, wenn es donnert. ${ }^{35}$

Another indication that these elements were widely used in the literary language is Smoler's (1841) Gesprăchsbuch. J. A. Smoler was one of the leading figures of the serbske narodne wozrodzenje in the 19th century and was particularly concerned about the creation of a modern, unified Sorbian literary language. The following are some examples found in Smoler (1841: 12) (examples are given in modern spelling).
(75) wone so blyska wone so porina hic wone (so) prósi wone (so) kapje wone so lije

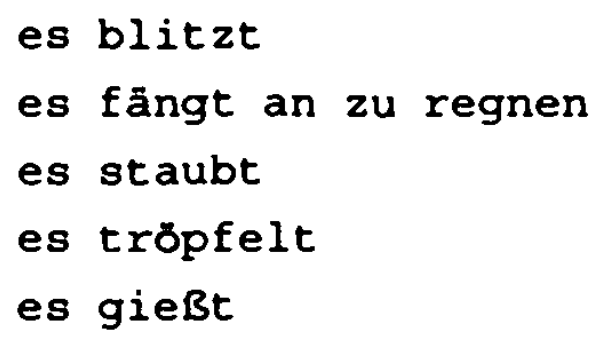

Compare this to the Gesprachsteil in Kral's (1895) grammar.
(76) chlodno je hižo překapuje je suche, mokre

\author{
es ist kühl \\ es fängt an zu regnen \\ es ist trocken, naß
}

35 The indeterminate pronoun and unknown subject Es ('it') is given as wono or wone, which is then the first word in the sentence: wono rima, es donnert ('it is thundering'): won $s$ dešrom a se snehom dze, es regnet und schneit zusammen ('it is raining and snowing at the same time'); wone zwoni, es läutet ('it is ringing'); wone so wujasnuje, es hellt sich auf ('it is getting lighter'). However, since the 3 rd person of the verb already shows the Es ('it'), wono is omitted in sentences with preceding conjunctions and other parts of speech: hdyz rima, wenn es donnert ('when it is thundering' '. ' 

je jara ćoplo
es ist sehr warm
płeco hißco mjerznje
es friert immer noch

The use of wone thus seems to have disappeared from the literary language in the second half of the 19 th century. It is virtually non-existent in today's written language. It seems fair to assume that the puristic movement associated with the serbske narodne wozrodienje artificially caused this sudden disappearance of overt non-referential pronouns from the literary language. Schuster-Šwc comes to a very similar conclusion when he writes (1974: 343 ):

Das Meiden des fiktiven Subjekts wono(e) in der neueren os. Schriftsprache dürfte zweifellos mit der seit Mitte des vergangenen Jahrhunderts verstărkt auftretenden Tendenz verbunden sein, die Schriftsprache stärker von der Volkssprache abzusetzen und damit auch fremde (d.i. deutsche) sprachliche Einflüsse zurückzudrăngen. ${ }^{36}$

According to Schuster-Šewc, overt expletive pronouns appear after 1850 sporadically in those literary works which intentionally reflect the Volkssprache. As a typical example he cites the writer A. Cerny, whose legends about Mythiske bytosce luziskich Serbow ('Mythical Beings of the Lusatian Sorbs') were published between 1890-95. This example may not be the most appropriate; Cerný was Czech by birth and might

36 'The avoidance of the fictitious subject wono(e) in the newer Upper Sorbian written language is undoubtedly connected to the strong tendency, starting in the middle of the last century, to separate the written language further from the vernacular language and thereby to push back alien (i.e. German) linguistic influences.' 
have introduced some linguistic "interference" with respect to the use of overt expletive pronouns. However, this should not affect the general validity of Schuster-Šwc's statement.

Schuster-Šewc (1974) points out that in some old Sorbian manuscripts there are examples of expletives which co-occur with referential subjects in the same sentence. Often they agree in pronominal features with the referential subject, making this phenomenon very reminiscent of the spoken Czech construction discussed above. The most typical text for this is Swetlik's (1690) translation of parts of the New Testament. from which the following examples are taken.

(77) Matthew 8.26

.... ha wona iom so sta jena wulka cichota and/expl. /refl. /happened/one/great/calmness

(78) Matthew 8.32 (cited from Michalk (1972: 93)

ha hlejco, monarm $z$ hujom wotendze ta cyla Erfodarm prez nahly spad do toho morja nut and/behold/expl . /with/quickness/went-away/ that/whole/herd/over/steep/fall/to/the/sea/inside

It is interesting to compare Swetlik's 1690 translation of various Biblical passages with the 1750 version of the same passages. The latter, according to Solta (1921: 33), should be considered as an edited swetlik translation rather than a completely new one. Surprisingly, the constructions with agreeing expletive-like elements seem to have virtually 
disappeared in the 1750 pericopes. The examples below provide some direct comparisons.

(79) a. Matthew $8: 13$ (Swetlik 1690)

ha won max rjekny Jrzus mex $k$ tomu hawtmanej: ... ha won be tón hol $\mathbf{n}_{\max }$ wustrowjeny wo tejsamej stundze. and/expl./said/Jesus/to/the/centurion/ and/expl. /was/that/boy/healed/in/same/hour

b. Matthew $8: 13$ (1750 pericopes)

ha Jðzus rjekny tomu hauptmanej: ... ha tón holc bo wustrowjeny wo tejsamoj stundze.

(80) a. Matthew $8: 8$ (1690)

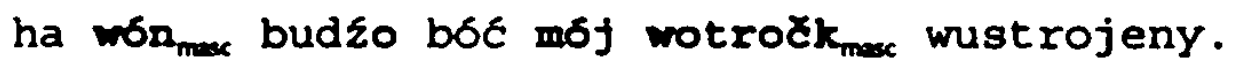
and/expl./will/be/my/servant/healed

b. Matthew $8: 8$ (1750) ha budze móf služowaik wustrowjeny.

(81) a. Matthew $8: 25$ (1690)

Ha wond pt płistupichu joho hurownik1 $k$ njomu. and/they/stepped-to/his/disciples/to/him

b. Matthew $8: 25$ (1750)

Ha Ei joho mučownicy stupichu $k$ njomu.

(82) a. Matthew $8: 3$ (1690)

Ha wón mex be hnydy tón joho musad mesc wuswarnjeny. and/expl. /was/immediately/this/his/leprosy/healed

b. Matthew $8: 3$ (1750)

Ha hnydy bó ton joho wusad wušwarnjeny. 
Since this difference between the two editions could not yet be due to puristic endeavors, it confirms my hypothesis that the construction with agreeing expletives was never really typical for old Sorbian. ${ }^{37}$ Instead, it was more or less part of Swettik's personal idiolect. Perhaps it was felt to be strange and thus removed by the editors of the 1750 version. One might speculate that Swetlik was particularly influenced by Czech constructions with agreeing expletives since he spent about ten years in Bohemia. However, a comparison with the analogous passages from the Wenceslaus Bible (1677) shows that this special feature of Swetlik's language could not be due to direct influence from the Czech Bible. As already mentioned above, there are also no instances of such expletives in the older Kralicka Bible (1613). It is thus more likely that Swetlik was influenced by spoken Czech.

\subsubsection{Upper Sorbian and German}

When considering the possible origin of non-referential pronouns in Upper Sorbian, one may consider German influence as a possible source.

(83) os regnet; os ist kalt; os ist dunkel

However, as first illustrated by Schuster-Sewc (1974), the

37 Also recall that there was only a very insignificant decline in the number of overt referential pronouns in the 1750 version compared to Swetlik (1690). For details see 4.4 . 
syntactic distribution of German es and Sorbian wone/wono is notably different. First of all, the occurrence of overt nonreferential pronouns in Upper Sorbian is always optional, even in those dialects which strongly prefer the version with the expletive. In German, certain non-referential pronouns, namely those which are subjects of the so-called "weatherverbs", are obligatorily overt, independent of their position in the sentence.
(84) a) es regnet morgen
'it is raining'
b) wann regnet as
'when is it raining'
c) weil es regnet
'because it is raining'

As explained above, in Sorbian, the expletive is barred from occurring in the syntactic positions in (84b) and (84c) because of the structure posited in (70). In German, the quasiargumental es which is associated with meteorological verbs can (and in fact must) co-occur with a wh-word in (Spec,CP] or a complementizer in position $C$. These distributional properties indicate that this type of German es is indeed the structural subject of the sentence. ${ }^{38}$

38 Es in these clauses is base-generated in [NP, IP], but may move to a different position at surface structure. The following structures assume that subordinate clauses represent the underlying word order and that root clauses are derived by obligatory movement of the finite verb into $c$.

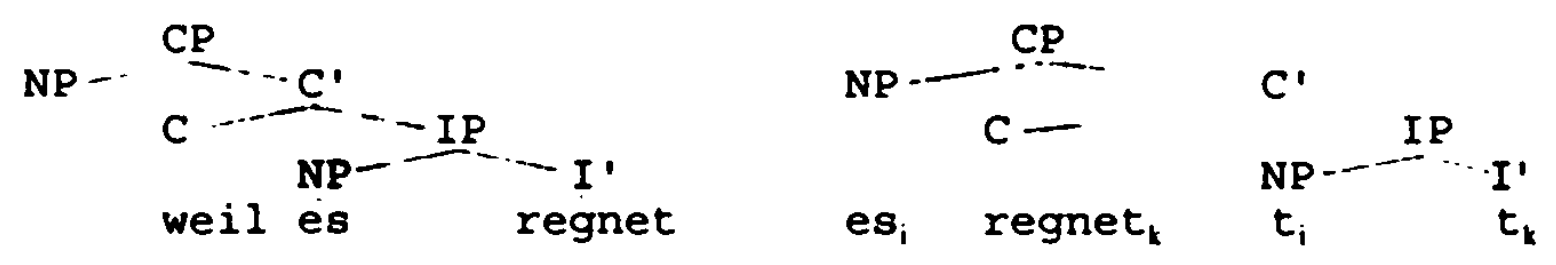


Michalk (1965a, 1977) cites some interesting instances of "Sorbisms" in German. Below are examples where Sorbian native speakers omit the (obligatory) German es, cited from Michalk (1965: 713) (\# indicates the place where the es is missing).

(85) und wenn [\#] dann soweit ist, dann 'and if [it] then is time, then'

(86) sehr kalt ist [\#] bei uns nicht mehr. ' [it] is not very cold anymore here'

(87) tagsüber taut [\#] noch 'during the day [it] is still thawing'

There is another type of German es which seems not to be a structural subject but resides rather in the same structural position as the Upper Sorbian non-referential wone, i.e. in [Spec,CP]. This is illustrated in the impersonal sentences below. 39

(88) a. es wurde viel getanzt und gesungen 'there was a lot of dancing and singing' b. .... weil (*os) viel getanzt und gesungen wurde c. wann wurde $(\star \bullet s)$ viel getanzt und gesungen

Examples (88b) and (88c) are ungrammatical for exactly the

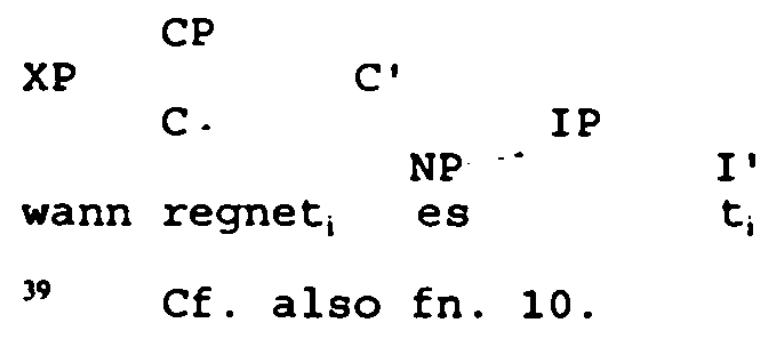


same reasons that Upper Sorbian wone and co-occurring subordinating conjunctions or wh-words are ungrammatical. This type of es is not a structural subject and therefore is not generated in [Spec,IP]. Instead, it seems to be inserted into [Spec,CP] due to language specific requirements that this position has to be lexically filled in German declarative root clauses. As illustrated earlier, sentence (88a) actually has an empty NP (pro) in subject position [NP, IP], which identifies German as a mixed pro-drop language. Referential and quasi-argumental subjects have to be overt; non-argumental subjects are obligatorily pro.

The German "non-subject" es and Upper Sorbian non-referential wone seem to serve the same purpose. In terms of functional sentence perspective they occupy the theme position, presumably to allow the core of the message to be placed toward the end of the sentence. Some Upper Sorbian speakers who reject the use of overt expletives consistently placed wonka ('outside') in sentence initial position, apparently to achieve the same results. The following examples were elicited in German.

(89) wonka so dešuje - es regnet

'outside it rains'

(90) wonka je zyma

- es ist kalt

'outside it's cold' 


\subsection{Summary}

In this chapter I analyzed the occurrence of expletive-like overt pronouns in Czech and Sorbian, which at first glance appear to pose problems for a licensing/identification system for null subjects. According to standard views of null-subject properties, the optional occurrence of overt non-referential pronouns is unexpected in any language where pro is licensed. I showed, first, that spoken Czech, despite its status as a canonical null-subject language, allows overt expletive subjects. However, because the use of Czech expletives is based on functional considerations, I argued that this phenomenon does not really contradict theoretical predictions made by the licensing/identification framework in conjunction with the avoid pronoun principle. Sentences with and without overt expletives are usually not totally synonymous, and it thus seems that Czech expletives can convey some special pragmatic meaning. Therefore they should be subsumed under the generally possible occurrence of overt subject pronouns in marked context. I then followed Trávnícek's argument about the possible derivation of such "functionally charged" expletives from a sentential interjection with the function of "drawing somebody's attention to something".

In contrast to Czech, no emotive component is associated with the use of expletives in Sorbian. However, the syntactic incompatibility of expletives with wh-phrases and complementizers indicates that expletives are not structural subjects. 
Instead I argued that these elements occupy [Spec,CP], presumably with pro in the subject position, which produces the structure [CP wone lippro taje]] ('it's thawing'). The positioning of Sorbian wone is analogous to and perhaps under the influence of German non-argumental es (which crucially does not include the subject of weather-verbs) which is inserted in Verb-second contexts and only legitimate in that context. In contrast to Sorbian, German has another type of non-referential es, the so-called quasi-argumental es, which is a real subject and must always be overt. This type of es is the subject of meteorological verbs in German. It follows then that in Sorbian, there is no difference in the position of wone in the following examples, while in Gexman there is a different position of es.

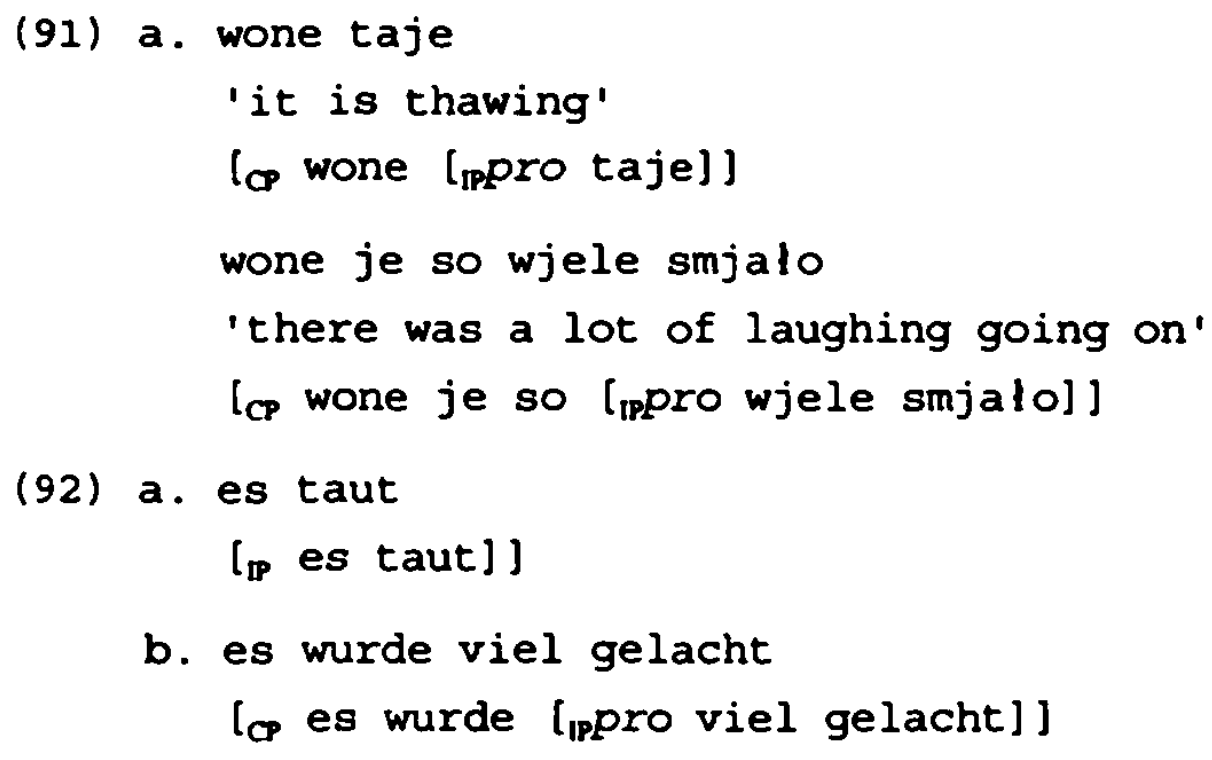




\section{CONCLUSION}

In this work I discussed data from Russian, Sorbian, and Czech which appear to challenge licensing/identification systems such as the one suggested by Jaeggli/Safir (1989). The application of a set of three null-subject diagnostics to slavic languages in Chapter 3 suggested that most West and South Slavic languages are canonical pro-drop languages, while Russian, taken to be representative of East Slavic, is not. After suggesting an intuitive explanation for this split. I set out to formalize the difference between these two groups in terms of the inconsistent realization of the functional projection $A G R_{\text {per }}$ in Russian.

In Chapter 4 I showed that Sorbian does not possess all the properties of a canonical null-subject language, despite claims to the contrary by language purists. To explain and illustrate this puristic error I cited numerous examples from the written language (drawn both from early and contemporary texts) and the spoken languages. This was followed by a critical discussion of three possible answers to the question of why Sorbian is not a canonical null-subject language. Within a licensing/identification system it would be necessary to answer the question of why the identification of thematic null subjects in Sorbian is blocked despite the obviously 'rich' verbal morphology. Two (more or less successful) models were then formulated. One was derived from the possibility that the number of syncretisms allowable for successful identifica- 
tion had been exceeded, and the other was based on word order, specifically the verb-final preference found in Sorbian, which is peculiar in Slavic. However, both of these models presented potential difficulties in the handling of certain data, or produced counter-intuitive predictions. In the final analysis it was determined that the licensing/identification system in its restricted form cannot account for the Sorbian data. As an alternative. I proposed a model in which Sorbian is analyzed as a truly optional pro-drop language in which pro is licensed and identified, and where the presence of atonic personal pronouns causes the null and overt variants to be in competition.

In chapter 5 I discussed the occurrence of overt expletives in Czech and Sorbian. This analysis led to the conclusion that these elements, though different in their syntactic status, are actually not a challenge for the predictions of possible language types made by the kind of identification and licensing system suggested by Jaeggli/Safir (1989) in conjunction with the avoid pronoun principle. 


\section{BIBLIOGRAPBY}

Avanesov R.I. and V.V. Ivanov. (1982) IstoriCeskaja grammatika russkogo jazyka. Moskva: Nauka.

Babby, L. (1989) "Subjectlessness, external subcategorization, and the Projection Principle". Zbornik za filologiju i lingvistika 32 : 7-39.

Bauer, J. (1968) "Strukturns typy slovanské vêty a jejich vívoj". Ceskoslovenské pł̌ednałky pro VI. mezinárodni sjezd slavistú. Praha: Akademia.

Benedicto, E. (1994) "Agr, $\theta$-features and V-movement: Identifying pro". University of Massachusetts occasional papers in Iinguistics 17: 1-18.

Bennis, H. and L. Haegemann. (1984) "On the status of agreement and relative clauses in West-Flemish". De Geest and putseys eds. Sentential complementation. Dordrecht: Foris, 33-53.

Berneker, E. (1900) Die Wortfolge in den slavischen Sprachen. Berlin: Behr's Verlag.

Bloomfield, L. (1935/1958) Language. New York:Holt and Co.

Borer, H. (1989) "Anaphoric AGR". Jaeggli O. and K.J. Safir eds. The null subject parameter. Dordrecht: Kluwer, 69-109.

Bouchard, D. (1989) On the content of empty categories. Dordrecht: Foris.

Cardinaletti, A. (1990) "Es pro and sentential arguments in German". Linguistische Berichte 126: 135-164.

Carlton, T. (1990) Introduction to the phonological history of the Slavic languages. Columbus, $\mathrm{OH}$ : Slavica.

Chomsky, N. (1981) Lectures on government and binding. Dordrecht: Foris.

Chomsky, N. (1982) Some concepts and consequences of the theory of government and binding. Cambridge, MA: MIT Press.

Chomsky, N. (1986) Barriers. Cambridge,MA: MIT Press.

Cernyx, P.J. (1954) IstoriCeskaja grammatika russkogo jazyka. Moskva: Nauka.

De Bray, R. (1963) Guide to the Slavonic languages. London: Dent \& Sons. 
Elle, L. (1991) "Die Sorben in der Statistik". Die Sorben in Deutschland. Bautzen: Maćica Serbska, 21-25.

Elle, L. (1992) "Zur Sprachsituation der Lausitzer Sorben" . Slavia Occidentalis 48/49: 67-83.

Emonds, J. (1976) A transformational approach to syntax. New York: Academic Press.

Faska, H. (1964) "Je personalny pronomen płi formje finitneho slowjesa njetrěbny?" Serbska కula 64: 572-576.

Faßke, H. (1979) "Semantika a distribucija personalnych pronomenow $w$ hornjoserbskej spisownej rexi". Letopis instituta za serbski ludospyt 26, 1-23.

FaBke, H. (1981) Grammatik der obersorbischen Schriftsprache der Gegenwart. Morphologie. (in conjunction with F. Michalk) Bautzen: VEB Domowina-Verlag.

Faßke, H. and F. Michalk (1989) "Dialektny tekst z Mjełic". Letopis instituta za serbski ludospyt 36: 38-52.

Feldstein, R. (1987) "Czyta vs. czytaj and the determination of Polish conjugational desinences" International journal of slavic linguistics and poetics XXXV-XXXVI: 65-76.

Franks, S. (1990) "On the status of null expletives". Lingua 81: $1-24$.

Franks, S. (1994) "Null subject characteristics of slavic languages". Paper presented at the annual meeting of the American Association of Teachers of Slavic and Eastern European Languages.

Franks, S. (1995) "Null subject phenomena". Parameters of Slavic morphosyntax. Cambridge: Oxford University Press.

Franks, S. and G. Greenberg. (1993) "The functional structure of Slavic clauses". Formal approaches to slavic linguistics: The Ann Arbor meeting. Ann Arbor: Slavica 77-108.

Gribble. C. (1973) Medieval Slavic texts. Cambridge, MA: Slavica.

Haegeman, L. (1994) Introduction to government \& binding theory. Cambridge,MA: Basil Blackwell.

Haider, H. (1991) "PRO-PLEME". Strukturen und Merkmale syntaktischer Kategorien. Tübingen: Gunter Narr. (studien zur deutschen Grammatik, 39.) 
Hammer, L.B. (1985) Prague colloquial Czech. Ph.D. dissertation. Indiana University.

Hirschova, M. (1984) "K jednomu typu výpovêds běznè mluvené testiny". Slovo i slovesnost 45: 273-275.

Holmberg, A, Nikanne U. (1994) "Expletives and subject positions in Finnish". Proceedings of NELS 24: 73-187.

Huang, C. -T. J. (1984) "On the distribution and reference of empty pronouns". Linguistic inquiry 15: 531-574.

Hyams, N. (1986) Language acquisition and the theory of parameters. Dordrecht: Reidel.

Innis, $J$. et al. (1985) Intermediate and advanced Russian reader. Ann Arbor: Ardis.

Ivanov, V.V. (1980) IstoriCeskaja grammatika russkogo jazyka. Moskva: Prosvescenie.

Jaeggli, O. (1982) Topics in Romance syntax. Dordrecht: Foris.

Jaeggli, O. (1986) "Arbitrary plural pronouns". Natural language and linguistic theory $4: 43-76.1$

Jaeggli, O. and N. Hyams. (1987) "Morphological uniformity and the setting of the null subject parameter". Proceeding of NELS 18: 238-253.

- Jaeggli. O. and K. Safir. (1989) Null subject parameter. Dordrecht: Kluwer.

Jagie, V. (1900) "Beiträge zur slavischen Syntax". Denkschriften der Kaiserlichen Akademie der Wissenschaften. XLVI: 1-88. Wien: Carl Gerold's Sohn.

Jakobson, R. (1939) "Signe Zéro". Bally, C. ed. Mélanges de Linguistique. Geneve: Georg et Cie.

Jakobson, R. (1948) "Russian conjugation" Selected writings II: 119-129. Mouton: The Hague.

Janas, P. (1984) Niedersorbische Grammatik. Bautzen: VEB Domowina-Verlag.

Jent. R. (1959) "Méstno finitnych formow pomocneho slowjesa a participa wuznamoweho slowjesa w hornjoserbskej sadze". Letopis instituta za serbski ludospyt 6: 3-47.

Jenc, R. (1964) "K prašenju normy w hornjoserbskej spisownej rěti". Serbska sula 17, 1964.4: 247-254. 
Jenc, R. (1965) "K prašenju normy $w$ hornjoserbskej spisownej ręi". Serbska కula 17, 1965.5: 309-317.

Jentsch, H., Michalk S. 1971. Sorbische Dialekttexte. IX Sãuritz, Ostro, Jauer, Kreis Kamenz. Bautzen: VEB Domowina-Verlag.

Jonas, D. and J.D. Bobaljik (1993) "Specs for subjects: The role of TP in Icelandic". MIT working papers in 1 inguistics 18: 59-98.

Jordan, F.P. (1841) Grammatik der sorbisch-wendischen Sprache. Prag: Friedrich Ehrlich.

King. T. (1993) Configuring topic and focus in Russian. Ph.D. dissertation, Stanford University.

Koch, J. (1991) Ha lecala je modra wróna. Bautzen: VEB Domowina-Verlag.

Koenitz, B. (1988) "Zur Charakteristik der Satzformen mit "expletivem" Personalpronomen im Tschechischen und Deutschen". Linguistische Arbeitsberichte 66:8-14, KarlMarx-Universität Leipzig.

Koktová, E. (1992) "Anaphoric expressions across clause boundary in pro-drop languages". Prague bulletin of mathematical Iinguistics 58: 39-63.

Kosta, P. (1990) "Zur formalen Lizensierung und inhaltlichen Determination leerer Subjekte im Russischen". Slawistische Beitráge 260: 117-165. München: Verlag Otto Sagner.

Kral, G. (1895) Grammatik der Wendischen Sprache in der Oberlausitz. Bautzen: Druck und Verlag von Schmaler.

Kroch, A. (1989) "Function and grammar in the history of English: Periphrastic do". Fasold, $R$. and $D$. Schiffrin (eds). Language change and variation. Amsterdam: Benjamins.

Kuen, H. (1957) "Die Gewohnheit der mehrfachen Bezeichnung des Subjekts in der Romania und die Gründe ihres Aufkommens". Syntactica und stilistica. (Festschrift für Gamillscheg) . Tübingen: Max Niemeyer.

Lamprecht, A. et al. (1986) Historická mluvnice Cestiny. Praha: Státní pedagogické nakladatelství.

Leinonen, M. (1983) "Generic zero subjects in Finnish and Russian". Scando-Slavica 29: 143-161. 
Liebsch, G. (1884) Syntax der wendischen sprache in der Oberlausitz. 1973 reprint. Bautzen: VEB Domowina-Verlag.

Lindseth, M. (1994) "Expletive and thematic subjects in West slavic". Studies in linguistic sciences 24.2: 333-346.

Lindseth, M. and S. Franks (1996). "Licensing and identification of null subjects in Slavic". In Formal approaches to slavic linguistics: The College Park meeting, 199-225.

Lindseth, M. Ludwig, J. (1992) "The overt, non-referential pronoun in Czech, Lusatian and German". Paper presented at the annual meeting of the American Association of Teachers of Slavic and Eastern European Languages.

Lorenz, K. (ed.) (1981) Serbska Citanka. Leipzig: Reclam.

Lotzsch, R. (1968) "Einige Auswirkungen des Purismus auf die grammatische Normierung slawischer Schriftsprachen". Sorabistiske płinołki $k$ VI. mjezynarodnemu kongresej slawistow w Praze 1968. Spisy instituta za serbski ludospyt 26. Bautzen: VEB Domowina-Verlag.

Meier, G.F. (1961) Das Zero-Problem in der Linguistik. Berlin: Akademie-Verlag.

Michalk, F. (1956-57) "Slowosled w Serbłxinje". Letopis instituta za serbski ludospyt 17: 1-29.

Michalk, F. (1962a) "Wliw nemxiny na polozenje finitneho slowesa w serbskej sadzen otázky slovanské syntaxe. Praha: Statni Pedagogické Nakldatelotvi.

Michalk, F. (1962b) "Der Einfluß des Deutschen auf die stellung des Verbum finitum im sorbischen Satz". Zeitschrift für Slavistik 62, 232-261.

Michalk, F. (1965a) "Wliw serbšciny na syntaksu němčiny we Luzicy". Serbska łula 18: 711-718.

Michalk, F. (1965b) "Enkliza w serbłcinje". Serbska క̌ula 18 : 124-128.

Michalk, F. (1970) "K prałenjam slowosleda w serbskich dialektach". Letopis instituta za serbski ludospyt 17: 1-29.

Michalk, F. (1972) "Latinizmy a germanizmy w rexi J. H. Swetlika". Letopis instituta za serbski ludospyt 19: 52-106.

Michalk, S. (1977) "Typische Erscheinungen des sorbischdeutschen Sprachkontakts". Methodische Beitrăge zum Sprachunterricht 1977: 75-105. 
Michalk, S. and H. Protze. (1974) studien zur sprachlichen Interferenz. Deutsch-sorbische Dialekttexte aus Radibor, Kreis Bautzen. Bautzen: VEB Domowina-Verlag.

Miklosich, F. (1883) Subjectlose Sătze. Wien: Wilhelm Braumüller.

Montalbelli, M. (1986) "How Pro is it?". Jaeggli, O. and SilvaCorvalan, C. eds. Studies in Romance Iinguistics. Dordrecht: Foris.

Müller, G. (1989) "Eine Geschichte ohne Subjekt. Zur Entwicklung der pro-Theorie". Linguistische Berichte 119: 3-52.

Nakhimovsky A.D. and R.L. Leed (1987) Advanced Russian. Columbus, $\mathrm{OH}$ : Slavica Publishers.

Nowak, H. (1988) Powedamy dolnoserbski. Gutes Niedersorbisch. Bautzen: VEB Domowina-Verlag.

Orełnik, Janez. (1986) "The obligatorium of unemphatic pronoun subjects in the Germanic languages". Filologija 14: 261269 .

Oschlies, W. (1991) Die Sorben - Slawisches Volk im Osten Deutschlands. Bonn: Friedrich-Ebert-Stiftung.

Perlmutter, D.M. (1971) Deep and surface structure constraints in syntax. New York: Holt, Rinehart and Winston.

Pétrancec, M. (1978) "Bjezsubjektowe werbalne sady $w$ rušinje a jich płelozk do serbłćiny". Diplomarbeit, Leipzig.

Pollock, J.Y. (1989) "Verb movement, universal grammar, and the structure of IPn. Linguistic inquiry 20:365-424.

Prince, E. F. (1993) "On the discourse functions of syntactic form in Yiddish: Expletive ES and subject-postposing".

Goldberg D. ed. The field of Yiddish. Evanston: Northwestern University Press.

Rizzi, L. (1982) Issues in Italian syntax. Dordrecht: Foris. (Chapter IV, "Negation, wh-movement and the null subject parameter")

Rizzi, L. (1986) "Null objects in Italian and the theory of pro". Linguistic inquiry 17: 501-557.

Roberge, Y. (1990) The syntactic recoverability of null arguments. Kingston: MCGill-Queen's University Press.

Roberts, I. (1993) Verbs and diachronic syntax. Dordrecht: Kluwer. 
Rohrbacher, B. (1995) "Explaining the syntactic consequences of "rich" agreement morphology: On the licensing of $\mathrm{V}$-toAgrs raising and pro". Proceedings of WCCFL 13: 350-364.

Safir, K. (1985) Syntactic chains. Cambridge University Press.

Schalich, G. (1970) Expressive sprachliche Mittel im modernen tschechischen Lustspiel. München: Fink Verlag.

Schneider, F. (1958) Grammatik der wendischen Sprache katholischen Dialect's. Bautzen: Hiecke.

Schuster-Šewc, H. (1967) Sorbische Sprachdenkmäler: 16.-18. Jahrhundert. Bautzen: VEB Domowina-Verlag.

Schuster-Šwc, H. (1974) "Satze mit fiktiven Subjekt vom Typ os. 'Wono so dešcuje / ns. to se pada' und ihre stellung in der slawischen Syntax". Zeitschrift für Slawistik 19: $340-352$.

Schuster-క̌ewc, H. (1976) Gramatika hornjoserbskeje rð̌e. Syntaksa. Bautzen: VEB Domowina-Verlag.

Seiler, A. (1830) Kurzgefaßte Grammatik der sorbischen Sprache. (Fotomechanischer Neudruck Bautzen: VEB DomowinaVerlag, 1973).

Short, D. (1994) "Czech". Comrie B. \& G. Corbett eds. The Slavonic languages. London: Routledge, 455-532.

Siebenschein, H. (1988) Deutsch-Tschechisches/Tschechisch Deutsches Worterbuch. Praha: statnI Pedagogicke Nakladatelství.

Smoler, J.A. (1841) Maty Serb. Wendisch-deutsche Gesprăche. Bautzen: Wellersche Buchhandlung.

Speas, M. (1994) "Null arguments in a theory of economy of projection". University of Massachusetts occasional papers in linguistics 17: 179-208.

Sperling, A. (1990) "Arbitrary pronominals in slavic". Unpublished manuscript, Indiana University.

SpieB, G. (1995) "Die sprachliche Situation bei den sorben in der Niederlausitz". Lextopis instituta za serbski ludospyt 42: 59-62, Sonderheft.

Sportiche, D. (1988) "A Theory of floating quantifiers and its corollaries for constituent structure". Linguistic inquiry 19: 425-449. 
Sprouse, R. and B. Vance (1995) "An Explanation for the decline of null pronouns in certain Germanic and Romance languages". To appear in Language creation and change: Creolization, diachrony, and development. MIT Press.

Solta. B. (1921) "Prêni hornjoserbski preložk biblije". Casopis Macicy Serbskeje, 3-34.

Solta, J. et al. (1984) Nowy biografiski slownik. Bautzen: VEB Domowina-Verlag.

stone, G. (1994) "Sorbian". Comrie B. \& G. Corbett eds. The Slavonic Languages. London: Routledge, 593-685.

Taraldsen, K.T. (1978) "On the nominative island condition, vacuous application and the that-trace filter". Mimeographed ms.. MIT, Cambridge; distributed by the Indiana University Linguistics Club, Bloomington, Indiana, 1980.

Tomaselli, A. (1982) "Das unpersönliche "es" - Eine Analyse im Rahmen der generativen Grammatik" . Linguistische Berichte 102: 171-190.

Townsend, C. (1990) A description of spoken Prague Czech. Columbus, $\mathrm{OH}$ : Slavica.

Trávnitek, F. (1951) Mluvnice spisovné cełtiny II. praha: Slovanské Nakladatelstvi.

Tránnitek, F. (1962) Historická mlunnice ceská III. praha: Státní Pedagogické Nakladatelství.

Tschernych, P.J. (1957) Historische Grammatik der russischen Sprache. Halle: Niemeyer.

Waurick, I. (1968) "Der Inhaltssatz im Niedersorbischen". Zur grammatischen und lexikalischen struktur der slawischen Gegenwartssprachen. Halle: Max Niemeyer, 113-130.

Williams, E. (1987) "Implicit arguments, the binding theory, and control". Natural language and linguistic theory 5: $151-180$.

Woolhiser, C. (1994) "Expletive pronouns in Slavic: Subject or topic?" Indiana University manuscript.

Zubatý, J. (1917) "Die 'man'-Sätze". Zeitschrift für vergleichende Sprachforschung XL: 478-520. 


\section{Bibles and Pericopes:}

Upper Sorbian: (in chronological order)

S.Matthaeus und S.Marcus, translated from German by $M$. Frencel, 1670 .

Swjate Scenja, Lekcijony ha Epistle na te Njedźele, ha swjate Dny toho cytoho Leta, translated from Latin by J.H. Swetlik, 1690 (pericopes).

Biblija, to je cyle Swjate Pismo Stareho a Noweho Zakona, translated from German by several Lutheran ministers. 1728 .

Swjate scenja, lekciony a epistle ... 1750 (pericopes)

Biblia, to je cyte Swjate Pismo Stareho a Noweho Zakona, translated from German by Kühn 1823.

Swjate stenja, lekciony a epistle ... 1848 (pericopes).

Zowy Zakon nałeho knjeza Jłzusa Chrystusa, translated by Jakub Buk, 1862.

Nowy zakón, do hornjoseb̧とiny po rjedźe Vulgaty pǐełożiłtaj. translated form Latin by $J$. Lustanski a M. Hornik, Budy̧in 1896.

Perikopy. Epistle, lekcije a scenja ... 1909 (pericopes).

Scenje po swjatym Mateju, originally translated by M. Frencel and newly translated by the Bible commission of Lutheran Sorbian ministers, 1960.

Swjate Pismo Noweho Zakonja, 1966.

Lower Sorbian:

Das niedersorbische Testament des Miklawus Jakubica, 1548. (publ. by H. Schuster-Sewc, Akademie-Verlag: Berlin, 1967.)

Nowy Testament, translated by G. Fabricius 1709 . 
Czech:

Biblí Svatá aneb všecka svatá písma starého i Nového Zákona. podle posledního vydání Kralického $z$ roku 1613. ("Kralická Bible")

Biblí Ceská 1677 ("Wenceslaus Bible").

Biblí đeská đili Písmo Svaté starého i Nového Zákona, 1889.

\section{Latin:}

Biblia Sacra, Vulgatae editionis, 1914 ("Latin Vulgate").

\section{German:}

Die Bibel oder die ganze Heilige Schrift, translated by $M$. Luther, 1522. 